Facsimile Price $\$ 9,10$
Microfilm Price $\$ 3,50$
Available from the
Office of Technical Services
Department of Commerce
Washington 25, D. C.
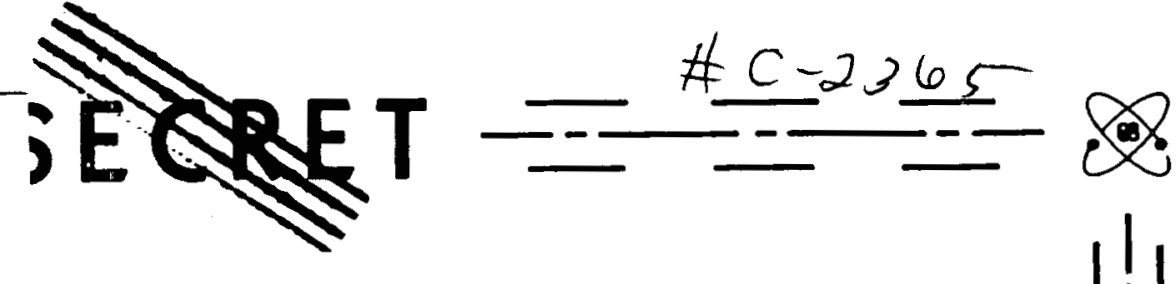

HAZARDS SUMMARY REPORT ON CRITICAL

EXPERIMENT PROGRAM NO. 1 AT CANEL

PWAC - 170

MAY 24, 1957

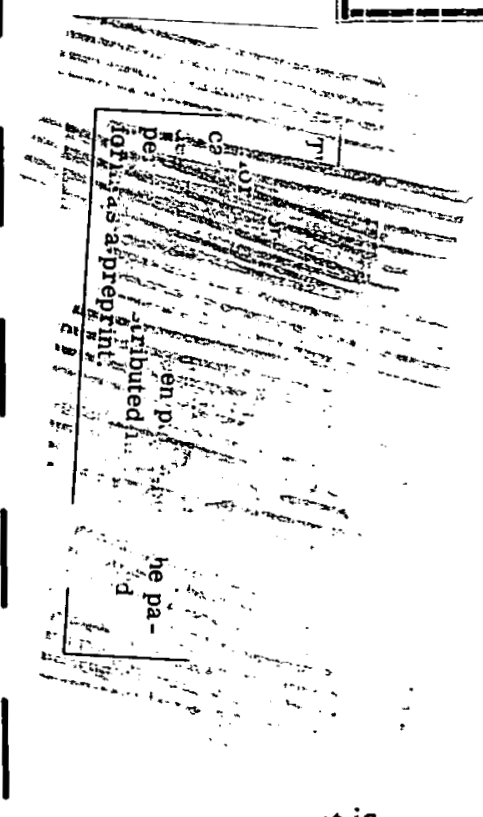

This document is
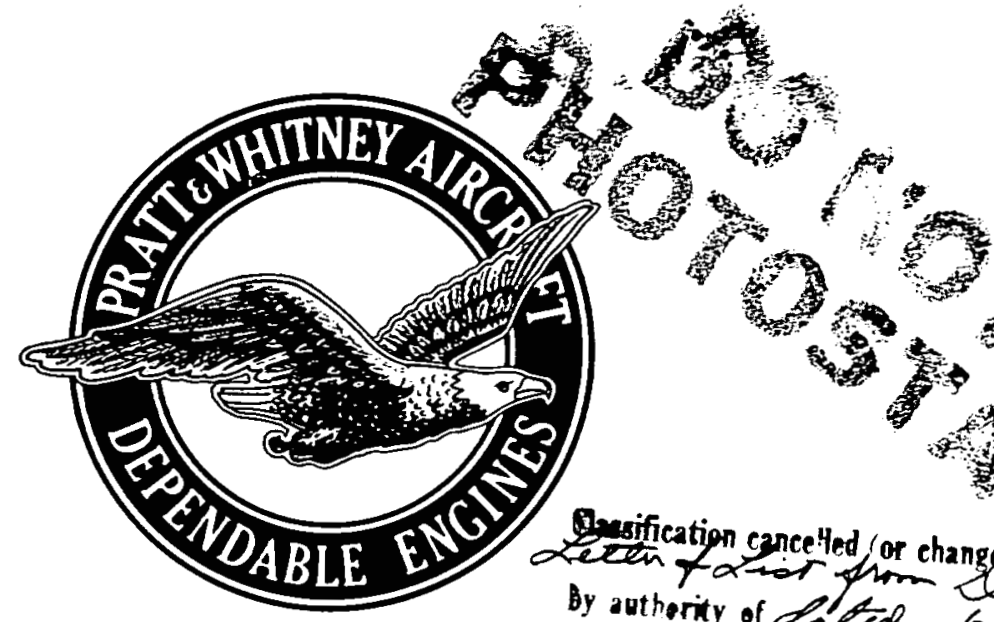

tis

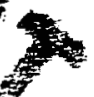

$\leftrightarrow$

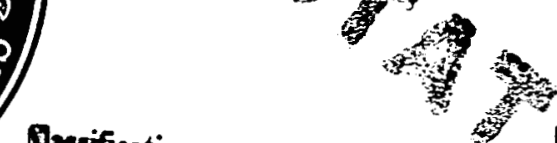

Geesification cancelled or changed to UNCUSS/FIED By anthority of Leter by.-g-3ale:

\title{
RESTRCTED DATA
}

TiE, date $2 \cdot 4 x^{1}$

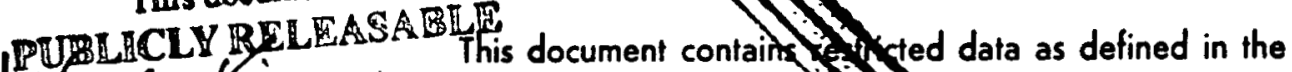

1 Huah husase Atomic Energy Act of 1951 is transmittal or the disAuthorizing Official Dateo 8800 closure of its contents in any 10 an unauthorized person is pronipited.

\begin{tabular}{|l|llllllllllllllllllllll|l}
1 & $P$ & $R$ & $A$ & $T$ & $T$ & $E$ & $W$ & $H$ & $I$ & $T$ & $N$ & $E$ & $Y$ & $A$ & $I$ & $R$ & $C$ & $R$ & $A$ & $F$ & $T$ & 1
\end{tabular} DIVISION OF UNITEDAIRCRAFT CORPORATION CANEL OPERATIONS MIDDLETOWN I CONNECT I C UT
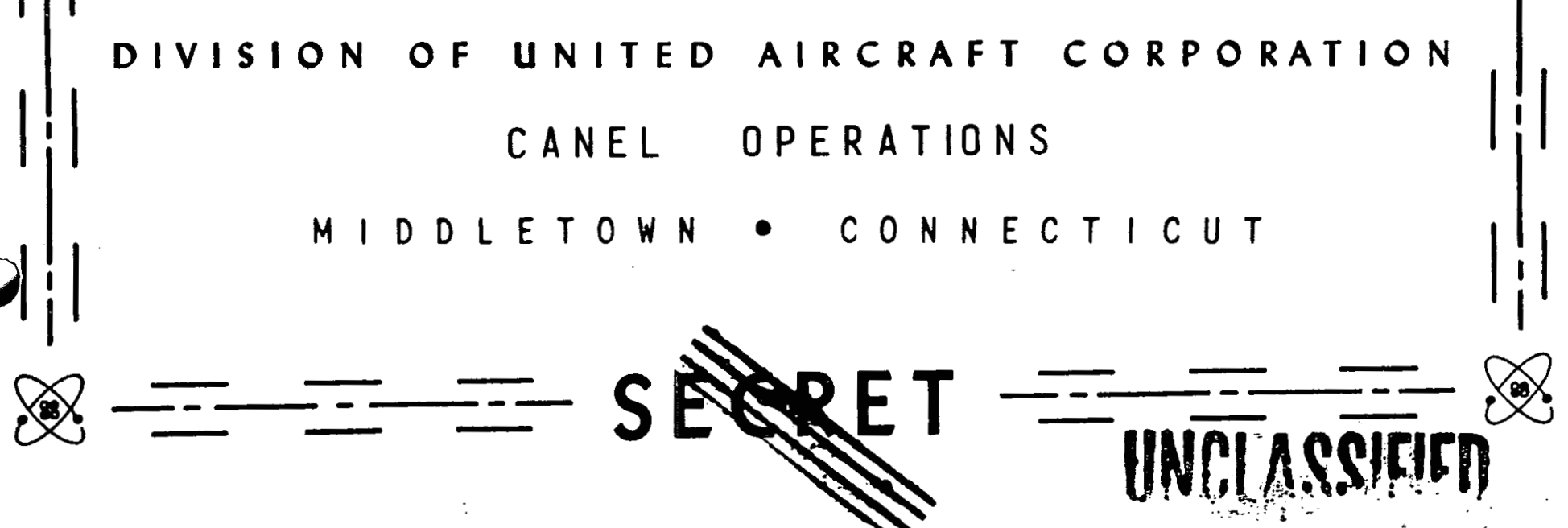


\section{DISCLAIMER}

This report was prepared as an account of work sponsored by an agency of the United States Government. Neither the United States Government nor any agency Thereof, nor any of their employees, makes any warranty, express or implied, or assumes any legal liability or responsibility for the accuracy, completeness, or usefulness of any information, apparatus, product, or process disclosed, or represents that its use would not infringe privately owned rights. Reference herein to any specific commercial product, process, or service by trade name, trademark, manufacturer, or otherwise does not necessarily constitute or imply its endorsement, recommendation, or favoring by the United States Government or any agency thereof. The views and opinions of authors expressed herein do not necessarily state or reflect those of the United States Government or any agency thereof. 


\section{DISCLAIMER}

Portions of this document may be illegible in electronic image products. Images are produced from the best available original document. 


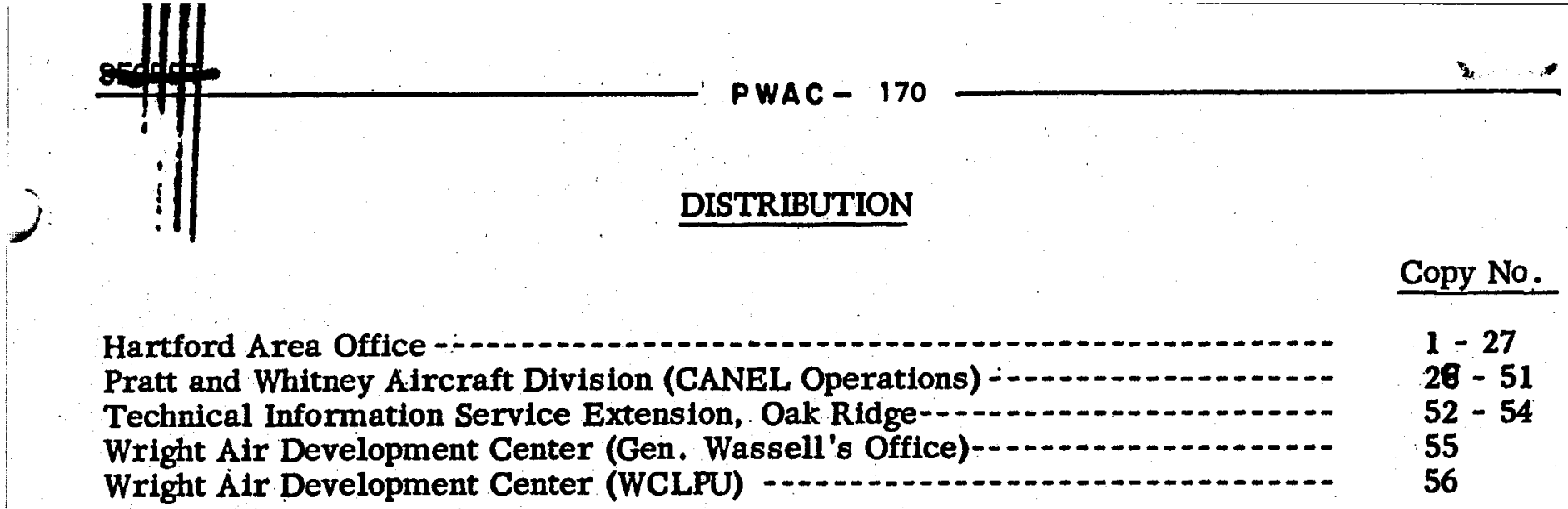

Hartford Area Office -
Pratt and Whitney Aircraft Division (CANEL Operations)
Technical Information Service Extension, Oak Ridge -27
Wright Air Development Center (Gen. Wassell's Office)
Wright Air Development Center (WCLPU)
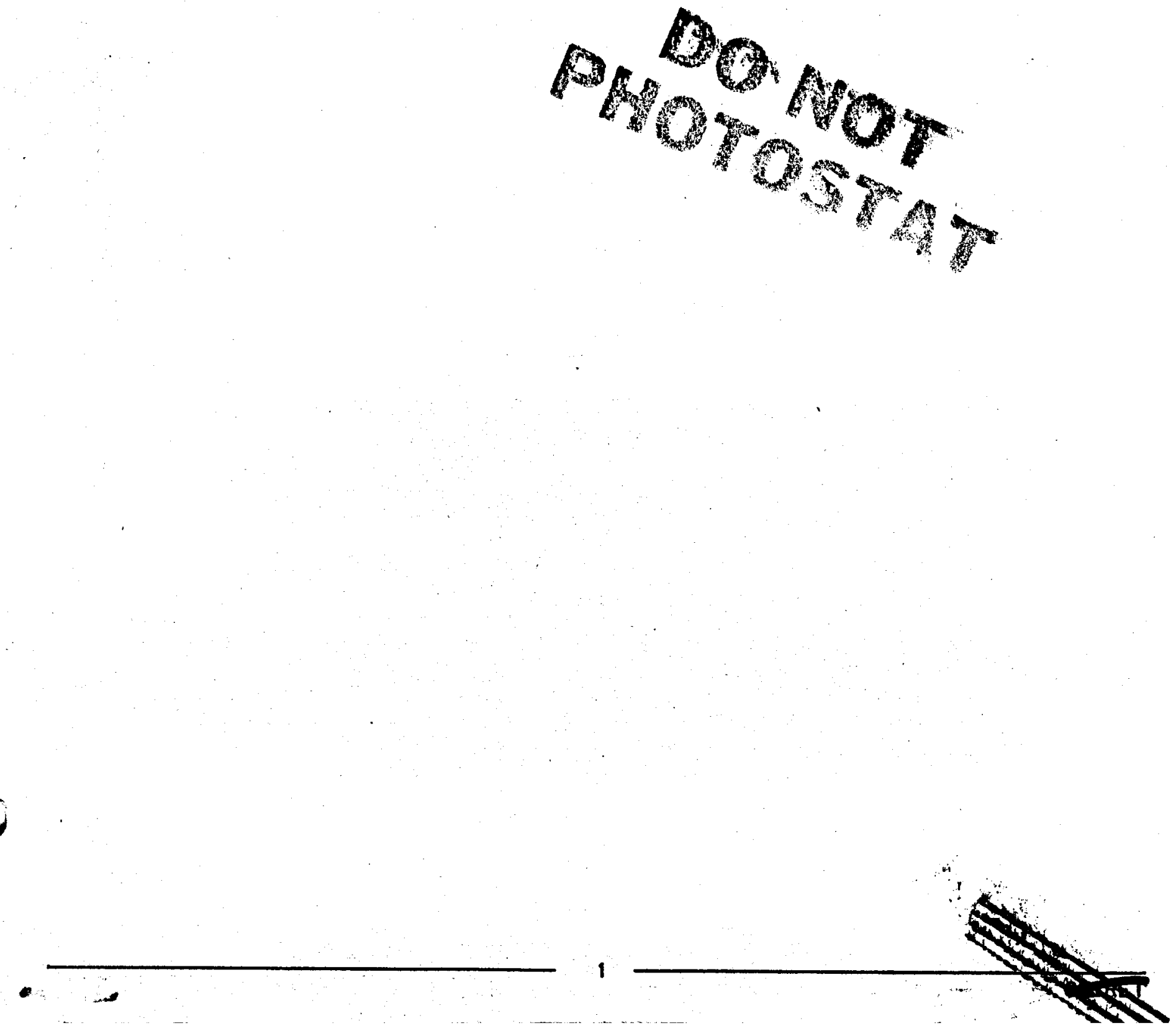


\section{TABLE OF CONTENTS}

Page No.

Table of Figures

I. Introduction and Summary 7

II. The Facility and Its Operation

A. Facility Location- 13

B. Building - 14

1. Test Cells

2. Control Rooms-14

3. Storage-Assembly Areas

4. Counting Room-_._. 17

5. Instrúment Room - 17

6. Other Laboratories, Shops, and Offices

7. Electric Power

8. Waste Disposal

9. Building Safety Features and Alarms 18

C. Description of Reactor Assembly 20

1. Power Reactor-10 20

2. Critical Assembly - 20

3. Assembly Table _... 30

4. Safety and Control Rods

a. Safety Rod Mechanism - 31

b. Control Rod Mechanism

5. Source -

6. Special Characteristics of the Critical Assembly

D. Instrumentation and Controls 38

1. General

2. Operational and Control Instrumentation

3. Safety Circuits

E. Types of Experiments

1. Critical Mass Studies -41

2. Control Evaluation

3. Control and Flux Distribution Measurements - 41

4. Reactivity Coefficients - 42

5. Optimization of Design

6. Operational Checks 42

7. Other Experiments

F. Plan of Normal Operation 43

1. Handling of Fissionable Material 
2. General Operation of a Critical Assembly

3. Initial Approach to Criticality

G. Safety Mechanisms

1. Table Separation - 45

2. Safety Rods (-...... 45

3. Control Rods -

4. Scram System -........ 45

5. Mechanisms to Prevent Unsafe Operation _.... 46

III. Hazards and Accidents

A. Hazards From Normal Operation

1. Fission Products -

2. Radiation-1- 51

B. Potential Hazards and Countermeasures

1. Improper Actions by Personnel

2. Equipment Malfunction

3. Flood, Fire, and Earthquake 55

C. Energy and Radioactivity Release in Case of Accident

1. General - 56

2. Maximum Reactivity Additions 56

D. Hazards to Surrounding Area - 59

1. General - 59

2. External Doses From Radioactive Cloud -...

3. Inhalation Doses . ........ 59

4. External Doses From Fallout and Rainout $\ldots \ldots \ldots$

5. Dose Conversions for Other Accidents

6. Beryllium Inhalation

7. Discussion $-\ldots . \ldots 3$

IV. Characteristics of Surrounding Area

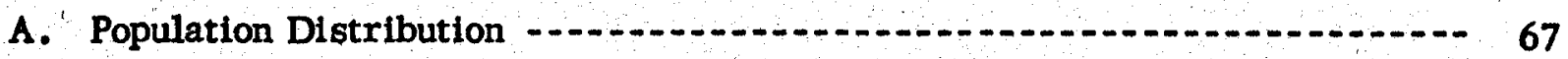

B. Vital Installations Near Site $-\cdots-1-71$

C. Railroad, River, and Automobile Traffic $-\ldots \ldots \ldots \ldots \ldots \ldots \ldots$

D. Meteorology $1-12073$

1. General : 73

2. Existing-Site Meteorological Data

a. Wind - Tent

b. Temperature Gradient 
Page No.

c. Dispersion Parameters

3. CANEL Meteorological Station 75

E. Geology and Hydrology 77

F. Seismology

V. Appendices

A. Analysis of Accident 81

B. Calculation of Effects on Surrounding Area 85

1. General Aspects -.. 85

2. External Doses from the Cloud 86

3. Inhalation Doses

4. External Doses from Fallout and Rainout 88

C. Industries Adjacent to Site 91

D. Meteorology 95

1. Introduction 95

2. Source of Data

3. Climatological Review of Hartford Area

a. Surface Wind Direction $-\ldots, 101$

b. Surface Wind Speed

c. Precipitation -.... 103

d. Atmosphere Stability - 103

4. Estimated Meteorological Difference Between
Hartford and the CANEL Site

E. Geology and Hydrology 110

1. Introduction - 110

2. Topography and Drainage

3. Geology -an 111

a. Bedrock - .

b. Unconsolidated Deposits (Overburden)

4. Hydrology -

a. Surface Water

b. Ground Water

5. Water Utilization

6. Earthquake History of Connecticut _

\section{$307 \quad 004$}




\section{TABLE OF FIGURES}

Figure No.

Title.

Page No.

Nuclear Physics Laboratory - First Floor Plan

Nuclear Physics Laboratory - Second Floor Plan

PWAR-5 Solid Fuel Element Reactor

Table With Grid Tubes and Framework in Place - Center View -.--

Table With Grid Tubes and Framework in Place - End View -...-.

Table With Grid Tubes and Framework in Place - Side View -

Partially Loaded Assembly With Control Drive Mechanism in Place

Table-Drive Control

Block Diagram of Instrumentation

15 Fission Energy Release Following Instantaneous

Reactivity Additions

Quantities Retained in Organs

CANEL Facility Site Plan-

Population Distribution

20 Radioisotopes and Organs Considered in Determining the

Inhalation Doses - -

21 Fraction of Infinite-Time Dose Received for Finite

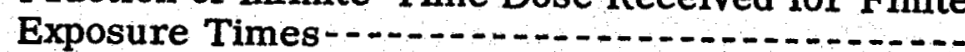

22 Listing of Labor Market Areas (Showing Cities \& Towns)

That Fall Within 10-Mile Radius of Site 
Summary of Industrial Workers Within 10-Mile Radius of Site by Type of Industry and Area

24 Sizes of Manufacturing \& Mechanical Establishments Located

Within a 10-Mile Radius of the Site 94

26 Percentage Frequency of Wind Direction, Weather Bureau

Airport Station, Hartford, Connecticut- 102

27 Percentage Frequency of Wind Speed Groups (mph), Weather

Bureau Airport Station, Hartford, Connecticut - 104

28 Comparative Wind Roses for Hartford, Conn ,, and CANEL _ _

29 Wind Rose for CANEL 200-Foot Level For One-Year Period-

Late March, 1956, Through March, 1957

30 Average Diurnal Wind Speed Variations at CANEL-

Late March, 1956, Through March, 1957

31 Average Temperature Difference Between Surface and Upper

Levels By Hours - May and June, 1956 109 


\section{INTRODUCTION AND SUMMARY}

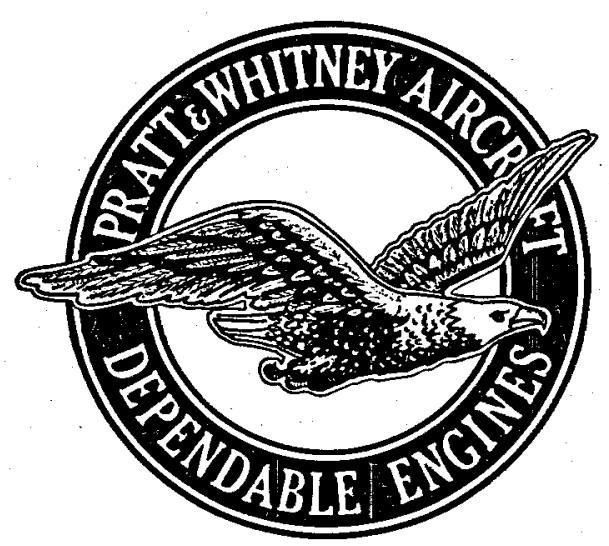

HAZARDS SUMMARY REPORT ON

CRITICAL EXPERIMENT PROGRAM NO. 1 AT CANEL

MAY 24, 1957 


\section{INTRODUCTION AND SUMMARY}

As part of the effort by Pratt \&. Whitney Aircraft to develop a nuclear powerplant for aircraft, a reactor system using solid fuel is being developed. This reactor, which is designed to work in the epithermal neutron energy range, is core-moderated by beryllium (or beryllium oxide) and has a large number of sodium-cooled fuel elements, containing uranium oxide dispersed in stainless steel. The reactor is controlled by rotating cylinders containing poison on one side. These cylinders are located in the reflector region, which is also composed of the moderating material. The physics and engineering analyses conducted on this system have indicated promising versions of this type reactor. However, a large amount of experimental information is needed to supplement the physics calculations.

Because of the urgent need for experimental information on this system and the unavailability of the Nuclear Physics Laboratory at the Connecticut Aircraft Nuclear Engine Laboratory until the spring of 1957 , the initial phases of the experiment were started at the critical facility of Battelle Memorial Institute of Columbus, Ohio, in the summer of 1956 . The critical assembly has been put together at Battelle using substantially the materials and mechanisms described in this report. The equipment has been fabricated and tested under actual operating conditions and the various components have proven to operate quite satisfactorily. The assembly first went critical in January, 1957, and has since produced answers which are in reasonable agreement with the analytical calculations. After occupation of the CANEL facility, the equipment operated at Battelle will be transferred to CANEL. Thus, when the experiments begin under the direct control of Pratt \& Whitney Aircraft, the program will enjoy both experienced personnel and proven equipment.

A Hazards Summary Report was submitted, and a presentation made to the Advisory Committee on Reactor Safeguards in October, 1955, which evaluated the Nuclear Physics Laboratory at the CANEL site. A Hazards Summary Report was also submitted to the committee by Battelle Memorial Institute in June, 1956, which evaluated the hazards pertinent to the critical experiments for this reactor with respect to the Battelle site.

The present report describes the critical experiment program to be performed at the CANEL Nuclear Physics Laboratory on a beryllium-moderated solid fuel reactor, for consideration and approval by the Reactor Hazards Evaluation Staff (and the Advisory Committee on Reactor Safeguards). Considerations are presented which are necessary to permit an examination of the hazards of this particular series of critical experiments.

Information is given on the nature and operation of the experimental assembly. Safety features of the building, equipment, and operations are pointed out. Possible accidents and the resulting hazards to surrounding areas are analyzed. Details of the surrounding area are described with supporting reports as appendices.

The Nuclear Physics Laboratory is located near the Connecticut River below Middletown, Connecticut, 1000 feet from the nearest laboratory installation and over one-half mile from the nearest residence. The building has two test cells with associated control rooms, vaults, laboratories, shop, and office area. For shielding, the test cells have 5 to 6 feet thick concrete walls and 3 feet thick cellings. Ventilation equipment will provide proper conditions for instruments and materials, maintain flow from clean to possibly contaminated areas, and isolate each cell and vault. Electric power is furnished from a dual supply system, with dual lines, plus a small local emergency unit. Water lines are excluded from the cells and vaults. Hold-up tanks are provided for. drains possibly carrying valuable or radioactive material. Other drainage is into the storm or sanitary sewage system. Normal air exhaust is passed through Atomic Energy Commission filters where desirable. Lights and alarms are distributed in and around the building to warn of fire and nuclear hazards. Communication systems are adequate to inform personnel of emergency conditions. 
The proposed critical assembly is composed of blocks of beryllium, tubes containing boron carbide, and fuel element assemblies. The fuel elements are composed of strips of stainless steel, aluminum, and uranium contained in a stainless steel box. The various materials will be loaded in halves into an aluminum gridwork which is mounted on a sṕlit table and brought together under carefully controlled"conditions to achieve criticality. Control and safety of the assembly is achieved by inserting or withdrawing certain fuel elements from the assembly. Speeds of table closure and control rod motion will be limited to provide safe rates of reactivity. increase. Interlocks will aid in following the proper sequence of operations. Instruments will keep operators informed of neutron density levels and changes at all times. In event neutron density levels become excessive, a scram system triggered automatically or manually will withdraw safety rods and separate the table halves.

Fissionable material not in use will be stored in vaults operated as accountability sub-stations. Vaults and test cells are adequately secured and alarmed.

Operating procedures call for safety review of plans, proper number and type of personnel required for operation, daily checks on instruments and safeties, and maintenance of adequate records. During initial approach to criticality with a new or significantly rearranged assembly, source multiplications will be measured as the fuel is added in small increments.

Experiments with the assembly will include determination of critical mass, control evaluation, flux and power distributions, reactivity coefficients of materials, and optimizations of design.

Hazardous situations could occur as a result of either inadvertent or sabotage actions by personnel, malfunction of equipment, autocatalytic characteristics, or catastrophes such as fire, flood, or earthquake. These are counteracted by selecting personnel, establishing and emphasizing safe procedures, maintaining a strong security system, providing interlocks and scram systems, using high-quality equipment designed to fail-safe, checking equipment frequently, minimizing use of flammable materials, and having adequate natural drainage.

A series of possible accidents have been analyzed, including instantaneous additions of reactivity up to 13 percent as well as gradual introduction of reactivity under the assumption that the safeties are inoperative. The mechanism of shutdown would be self-disassembly caused by pressure of vaporized fuel. The maximum accident for which a mechanism could be postulated is the introduction of 3.2 dollars per second which would result in a release of 58 megawattseconds of fission energy. The maximum conceivable accident equivalent to sabotage is given as the instantaneous introduction of 13 percent reactivity with a resulting release of 1500 megawatt-seconds of fission energy.

Conservatively calculated doses indicate that the general public will be exposed to considerably * less than LD50 amounts under the worst conditions, short of extreme sabotage.

The nearest large community is Middletown with a population of 20,000 located 5 miles to the northwest. The nearest vital installation is a steam-electric generating station 1 mile northwest. Winds are generally from the north in winter and from the south in summer, with speed averaging between 4 and 12 miles per hour. Local drainage will be into the river. Probability of earthquakes is slight. 


\section{THE FACILITY AND ITS OPERATION}

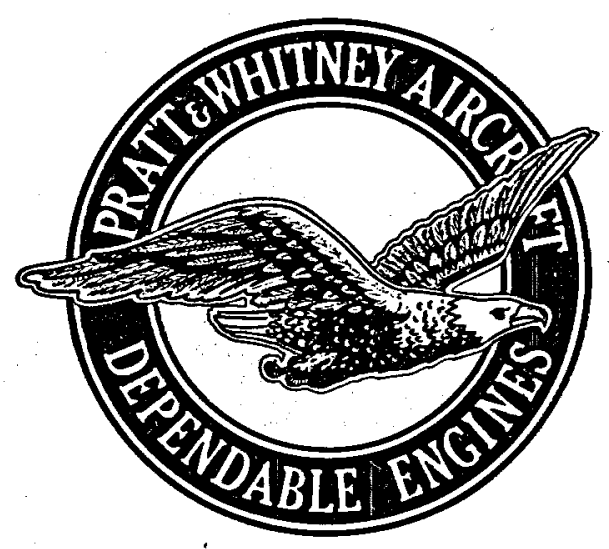

4.

\section{HAZARDS SUMMARY REPORT ON \\ CRITICAL EXPERIMENT PROGRAM NO. 1 AT CANEL \\ MAY 24, 1957}

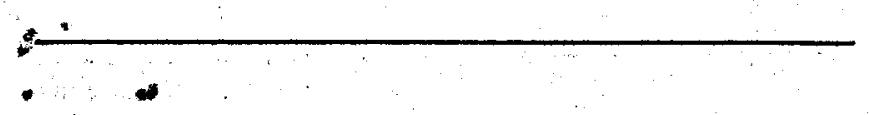




\section{A. FACILITY LOCATION}

The Nuclear Physics Laboratory is located in the northern half of the Connecticut Aircraft Nuclear Engine Laboratory (CANEL) site on the Connecticut River below Middletown, Connecticut. The population on the site will be at a distance of approximately 1000 feet or more from the laboratory, and generally outside an exclusion fence at that radius. The nearest residence is about $\mathbf{3 0 0 0}$ feet away. The laboratory is in an area of wooded hills sloping to the river, with gullies formed by small streams carrying surface drainage. The maximum flood height of the river is about $27 \mathrm{feet}$, which is far below the 140-foot elevation of the building floor. Local flooding of the building is prevented since it is built on a projection from benchland and is surrounded on three sides by steep downward slopes .

Further information on the surrounding area will be given in a later section of this report. 


\section{B. BUILDING}

The floor plans and elevations for the Nuclear Physics Laboratory building are shown in Figs 1 and 2. The building consists of two high-bay test cells with associated assembly rooms and storage vaults in between, control rooms adjacent on two levels, and an adjoining section containing a counting room, laboratories, locker rooms, offices, etc., on the ground floor. Services, consisting mostly of ventilating equipment, are contained in two rooms, one over the assembly-storage areas and one over the laboratory area. The cells and counting room are of concrete construction; the assembly-storage rooms are concrete with brick partitions. The remaining sections of the bullding have steel panel siding and either steel panel or concrete block partitions. The entire building has concrete slab floors. Additional finish materials are provided where desirable.

\section{Test Cells}

Each test cell is 41 feet long, 40 feet wide, and 40 feet high, providing a total inclosed volume of $65,600 \mathrm{cu} \mathrm{ft}$.

The shielding walls and ceiling of the cells are made of reinforced ordinary concrete. . The wall on the control room side is 6 feet thick and the other three walls 5 feet thick. The walls are full thickness their entire height, except for a 2-foot jog near the top where there are crane rails. The ceiling is 3 feet thick.

In the wall opposite the control rooms, each cell has at ground level a personnel door (about 3.5 by 7 feet) and a truck door (about 10 by 12 feet). A second personnel door is provided on the upper level over the storage vault. These doors have shielding values approximately the same as the wall.

The personnel doors are constructed to permit manual operation in event of power failure. Locks and alarms will be provided consistent with safety and security regulations as described later.

Each cell has a separate ventilation system, located in the service area, designed to maintain constant temperature and to limit relative humidity to 45 percent. Fresh air is drawn in through dust filters, conditioned, and delivered to the cell through a labyrinth duct over one wall. Air returning for recirculation passes through Atomic Energy Commission filters and through a similar duct. A fraction of the air is exhausted at the ceiling through similar filters and a labyrinth by means of a blower which can be set to maintain a slight negative pressure in the cell. A larger blower is available for more rapid purging if desirable. A short stack on the roof will direct exhaust air upward. Quick-closing dampers are provided in the ducts between the cell and ventilation equipment and will be closed upon power failure, scram, or pressure surge. At the same time the air circulating blowers will turn off. To relieve a pressure surge, a blast relief damper will open by breaking restraining bolts at a preset pressure and allow exhaust through a labyrinth duct and up a second short stack on the roof. Seals around doors and other openings reduce leakage into the building.

Passages for conduits between the test cells and the adjoining rooms are provided in the form of five 4-inch offeet pipes to each assembly room and eight to each control room near the ceiling, and two 9 by 18-inch floor trenches going under the wall into each lower control room. When not in use, pipes will be plugged and sealed. Leakage through the trenches' can be controlled by using bulkheads or by filling with a solid material such as paraffin. 


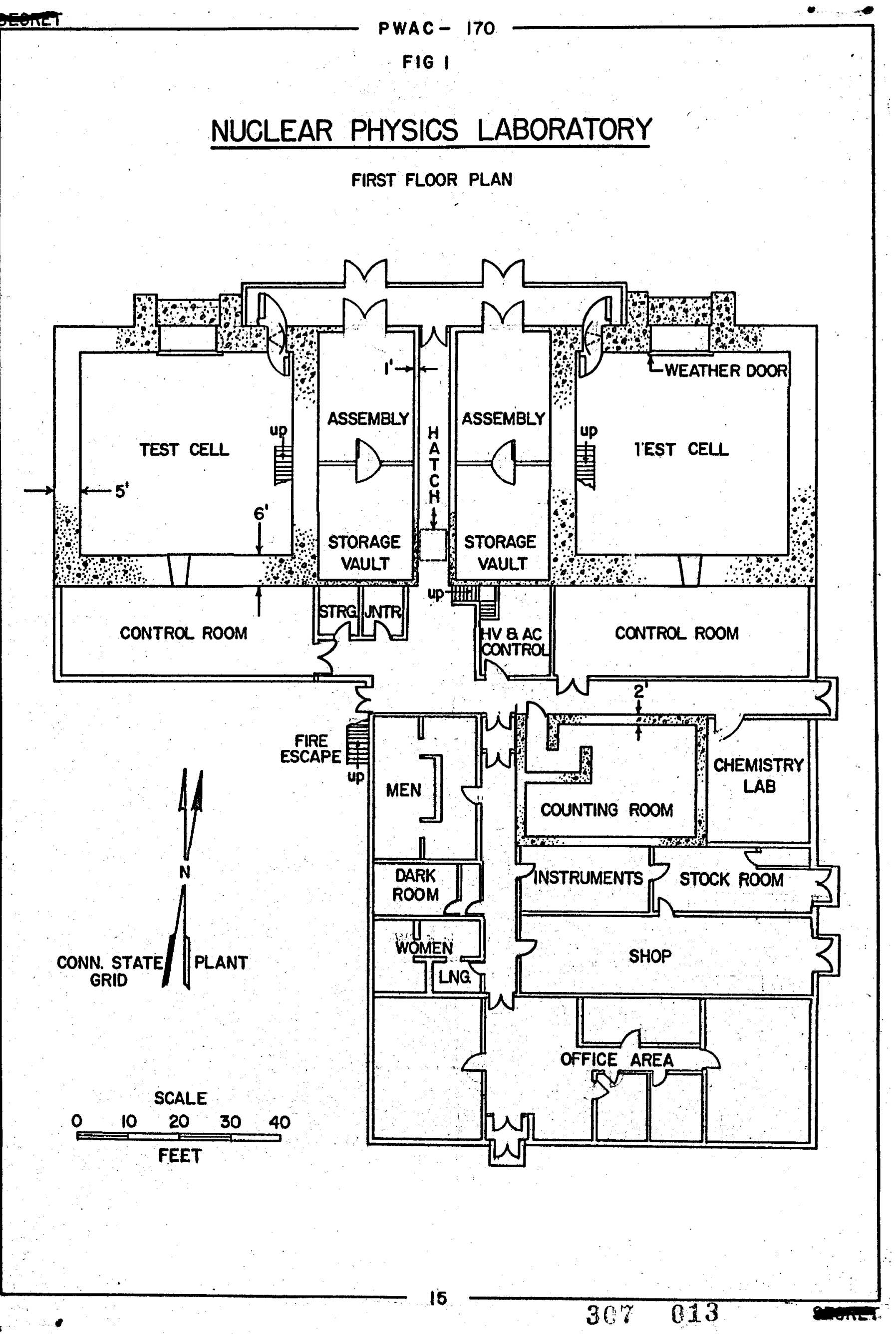


PWAC - 170

FIG 2

NUCLEAR PHYSICS LABORATORY

SECOND FLOOR PLAN

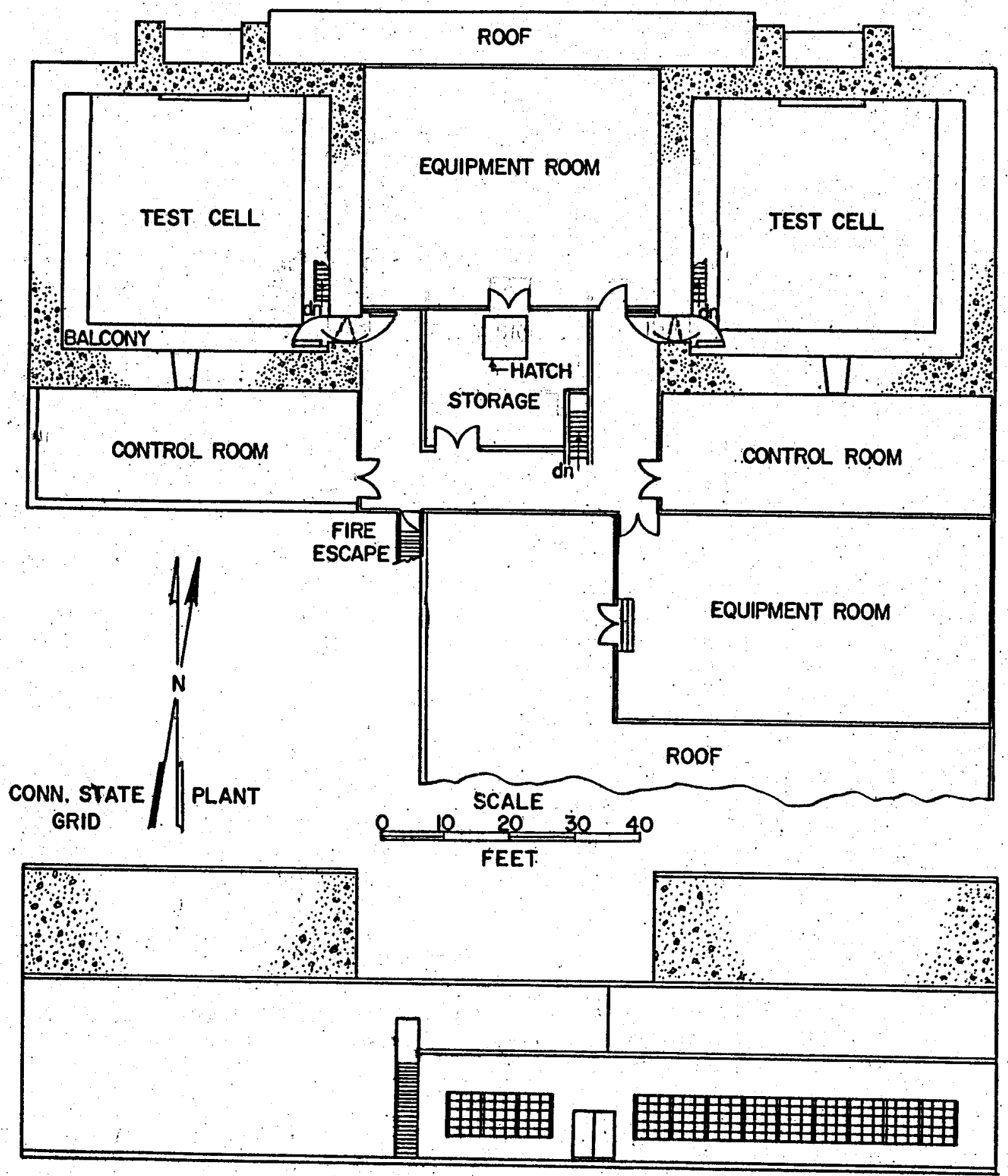

SOUTH ELEVATION 
Each cell is provided with an overhead traveling crane. Incandescent lighting is used. Electrical and compressed air outlets are furnished. No water supply line or drain is present in the cells. The concrete floor is covered with strips of Vinyl material.

\section{Control Rooms}

Each control room is 18 feet wide by 50 feet long. Control equipment will be located and operated initially at the lower level, but can be located and operated from the upper level as well when required by the nature of the test. Control from both levels will be possible if necessary. Constant temperature and a limit of 45 percent relative humidity will be maintained in the control rooms. Consoles for primary operating and recording equipment will be set up in the center of the room. Auxiliary equipment including connection panels, relay cabinets and the like will be located to one side or along the walls, where readily accessible for servicing. Trenches from the cells extend across and around the room to accommodate wires and other conduits.

Direct viewing of the test assemblies is provided by means of a zinc-bromide window in each control room. The windows are sufficiently large to provide a horizontal viewing angle of 120 degrees.

\section{Storage-Assembly Areas}

Each storage-assembly area is approximately 19 feet wide by 49 feet long, with one 5foot thick wall common with a test cell. Other walls are 12 inches of concrete, and the floor and ceiling are 10 and 9 inches of reinforced concrete, respectively. Each area has a separate ventilation system providing constant temperature and low humidity. Intake air passes through a dust filter and the discharge air through an Atomic Energy Commission filter. The floors are covered with wide-strip Vinyl material. No water plpes or drains are present.

Each storage-assembly area is divided into two sections by a 12 -inch thick brick partition with a vault-type door and grill gate. In the assembly section will be work tables, storage bins and carts, and material-handling equipment for preassembly and subassembly work. Exhaust hoods or boxes may be installed if dry boxes are not adequate when handling contaminated materials. In the storage vault section racks will be provided to limit the amount and control the distribution of stored fissionable material according to established practice for assuring non-critical condition, even if flooded.

\section{Counting Room}

The counting room is 22 by 33 feet with labyrinth entrance and 2-foot thick walls and ceiling of ordinary concrete for shielding. Constant temperature and limited humidity of 45 percent will be maintained. Incandescent lights are used. A well-grounded bus bar is included.

\section{Instrument Room}

The instrument room, used for work on instruments and control devices, also will be provided with constant temperature, limited humidity air, and is equipped with a wellgrounded bus bar, and incandescent lighting.

6. Other Laboratories, Shops, and Offices

The remainder of the first floor space includes a small darkroom, chemistry laboratory stock room, shop, locker rooms, and offices. 


\section{Electric Power}

Electric power is available to the building via two separate lines entering the building from different directions. Operation will normally be on purchased power and CANEL: generated power simultaneously. In the event of purchased power failure, generated power will continue to be supplied by the CANEL powerplant and routed through either or both lines. It is considered highly unlikely that both power lines will be inoperative simultaneously. A battery-powered motor-generator set will be available locally for such contingencies to operate some of the radiation monitoring equipment, and battery-powered lights will provide illumination.

8. Waste Disposal

Under normal operating conditions the amount of contamination in waste from the building will be very small. Routine checks will be made, and a number of features are included to take care of unusual conditions.

Most of any airborne contamination will originate in the test cells. As explained above, the normal exhaust passes through an Atomic Energy Commission filter which removes almost all particulate matter. The mechanism of relieving pressure surge has also been described, and the amount of radioactivity and the resulting hazards associated with such a pressure surge will be covered in later sections of the report. Small amounts of airborne contamination may originate from the assembly-storage areas or chemistry laboratory. These rooms have individual exhausts with Atomic Energy Commission filters.

No contamination of liquid wastes is expected other than minor amounts of material washed down drains. Drains for which the likelihood of this is the greatest, such as those for emergency showers, janitor's sink, chemistry laboratory and lavatories near the test cells, are connected to holding tanks which will be monitored before being emptied. This system serves a second purpose of recovering valuable materials. Water from the roof and the air-conditioning equipment flows into the process sewer system emptying into the river. Ground water around the building will flow into a surface drainage system leading to the river. Remaining drains are connected to the CANEL sanitary sewage system.

\section{Building Safety Features and Alarms}

The ventilation system in the building is designed not only to provide controlled temperature and humidity and/or flow isolation of some of the rooms as described above, but. also to maintain a general pattern of airflow from clean areas toward areas more likely to become contaminated. This is accomplished by having forced ventilation with appropriate adjustable dampers and louvers in ducts and doors, plus doors at each end of the corridor running from the office area, to assist in establishing and maintaining a pressure gradient.

As noted above, scram in a test cell will shut down the corresponding ventilation system. An electrical panel is provided at a key location whereby the ventilation systems in the rest of the building can be shut down promptly if necessary.

On both floors in the corridors between the control rooms, hand and eyewashing facilities and an emergency shower are provided.

Fire alarm boxes and bells are distributed throughout the building and connect with the central CANEL system. Fire detecting devices are installed where practical in the test 
cells, vaults, and control rooms. Met-L-X extinguishers will be placed in the cells and assembly-storage areas and appropriate types in other areas. There is a fire escape from the central corridor on the second level.

Lighted signs to indicate when test reactors are operating are placed in the office area, control rooms, central and rear corridors, on outside corners and at entrance roads. The scram of an assembly will cause the corresponding lights to flash and warning horns in and around the building to sound.

The building intercom system includes a few key stations located in the control rooms and elsewhere from which annouricements during an emergency can be made to all other stations, including speakers in the areas not covered by individual boxes.

Another set of speakers in the building is connected to the CANEL central paging system which can be used by the central emergency headquarters for announcements regarding air raids, accidents in other buildings, etc. 


\section{DESCRIPTION OF REACTOR ASSEMBLY}

\section{Power Reactor}

The power reactor for which these critical studies are to be conducted as yet has no fixed design configuration, but studies have indicated some initial designs and a range of possible changes. Fig 3 shows a schematic drawing of a possible final design. The core is a right circular cylinder approximately 30 inches in diameter and 30 inches high. It will contain 250 to 320 fuel elements. One of the designs under consideration for these fuel elements incorporates uranium oxide dispersed in stainless steel wafers approximately 1-inch in diameter and stacked in stainless steel tubes 30 inches long. Numerous small-diameter tubes run through the wafers to provide coolant passages. The fuel elements and the moderator are sodium-cooled. The core moderator and the reflector material is beryllium, or beryllium oxide. The end reflector is about 5 inches and the side reflector may range from approximately 5 to 8 inches. The reactor is controlled by six to ten cylinders located in the side reflector. These cylinders are 5 to 8 inches in diameter and have a 120-degree sector filled with elements containing boron carbide and the remainder with the reflector material. The cylinders may be rotated to effect control by moving the boron carbide nearer or farther from the core. The core and the control cylinders are housed in stainless steel shells, and there are thick stainless steel end plates to retain the fuel elements.

Some of the desired characteristics of the reactor are that the peak-to-average power ratio over the core region be some reasonably low value in the neighborhood of 1.2 and that the spectrum of the fission flux be sufficiently non-thermal to minimize effects of xenon poisoning. The control cylinders should be able to provide enough change in reactivity (estimated at 13 percent) to be capable of controlling the reactor from the new cold condition to the end-of-life.

The critical assembly work will attempt to evaluate these factors and optimize them if necessary.

\section{Critical Assembly}

The mock-up reactor for the critical experiment will be constructed with its axis horizontal and will be divided into two equal parts at the mid-plane perpendicular to the axis. Each half of the core will be loaded on half of a split-table structure. One half of the table will be stationary while the other will be movable in a horizontal direction. The table and its drive system are shown in Fig 4. Aluminum grid tubes 3 inches square by 36 inches long, with 45 mil thick walls, will be stacked on the beds of both the movable and fixed table halves. The simulated fuel elements, moderator, and reflector pieces will be placed in in these tubes. Each table half will have 576 tubes stacked in a 24 by 24 tube array. These tubes will be held rigidly by clamping frames fastened to the table. When the table halves are run together, the tubes form a "honeycombed" cube which is 6 feet on a side. Figs 5 through 8 show various views of the grid tubes stacked on the table.

The mock-up fuel elements will be made up of strips of uranium and stainless steel representing the matrix and cladding material, aluminum representing the sodium coolant, and sometimes other materials representing fission product poisons. These strips will be stacked in boxes made of $18 \mathrm{mil}$ stainless steel, having outside dimensions of 0.96 by 0.96 by 20 inches. These boxes are equipped with $10 \mathrm{mil}$ covers to form a closed container for the fuel elements in the mock-up which will simulate closely the elements in the reactor design, A drawing of these elements is given in Fig 9. 


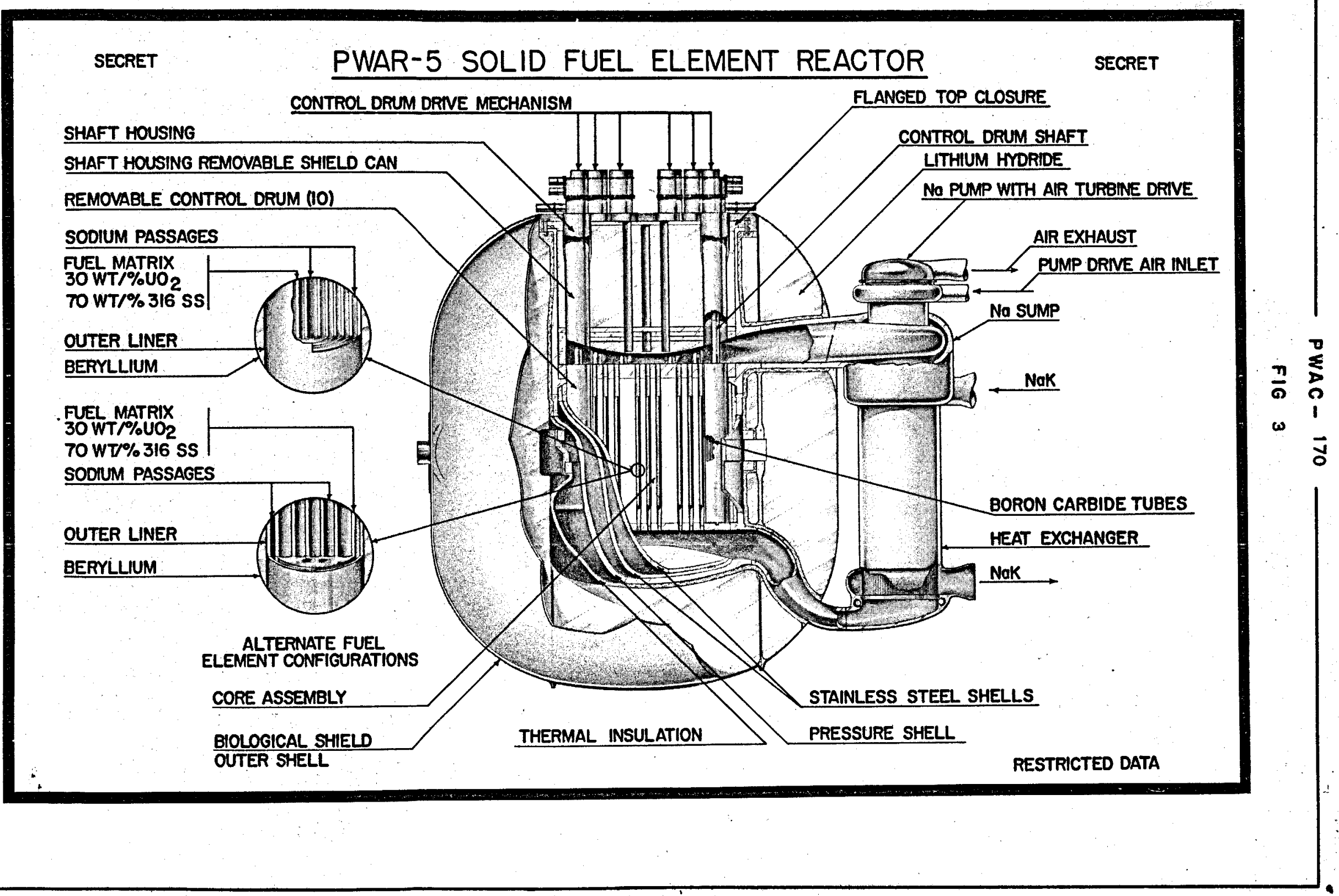




\section{ASSEMBLY TABLE AND TABLE-DRIVE SYSTEM}

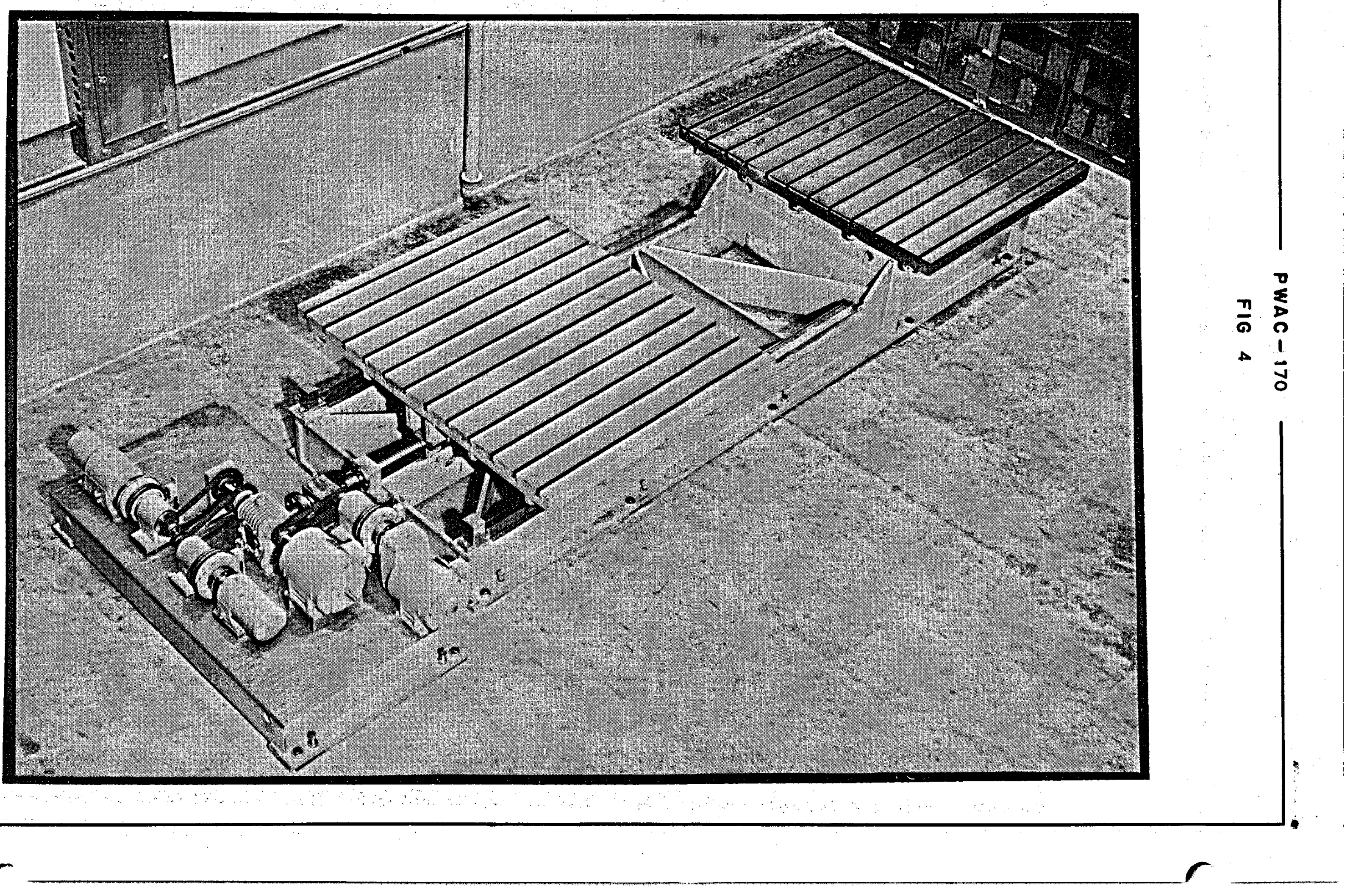




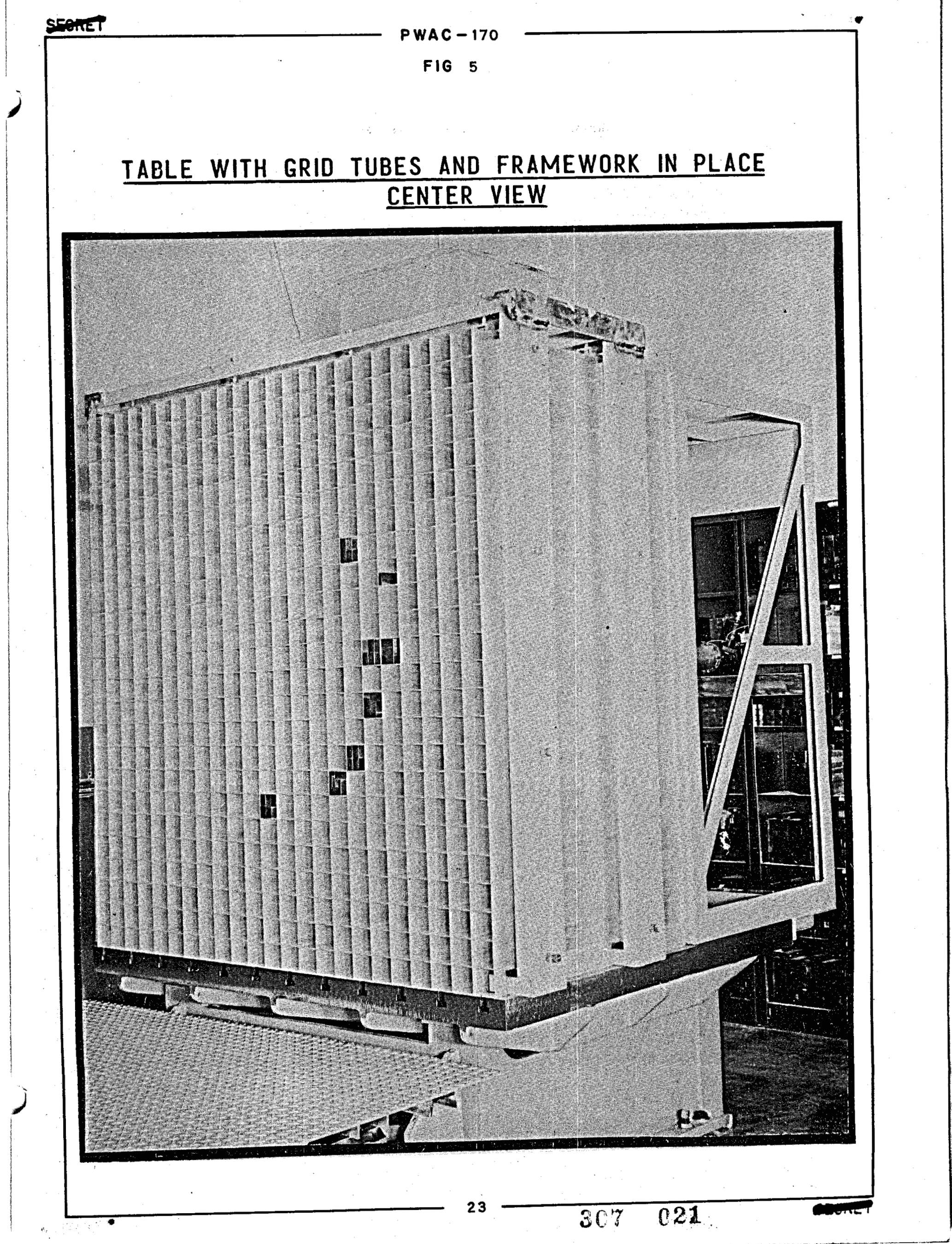


PWAC - 170

FIG 6

TABLE WITH GRID TUBES AND FRAMEWORK IN PLACE END VIEW

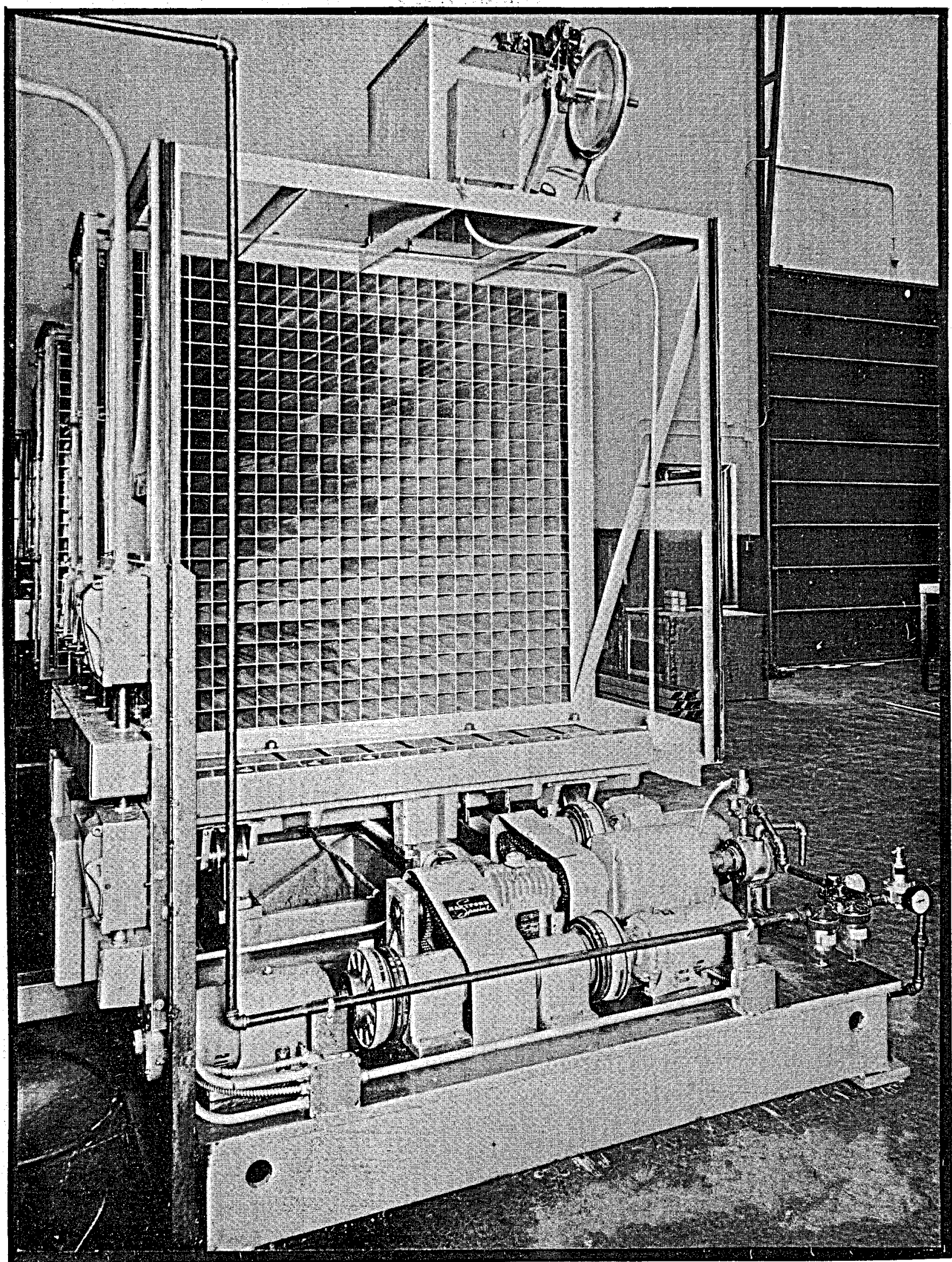



SIDE VIEW

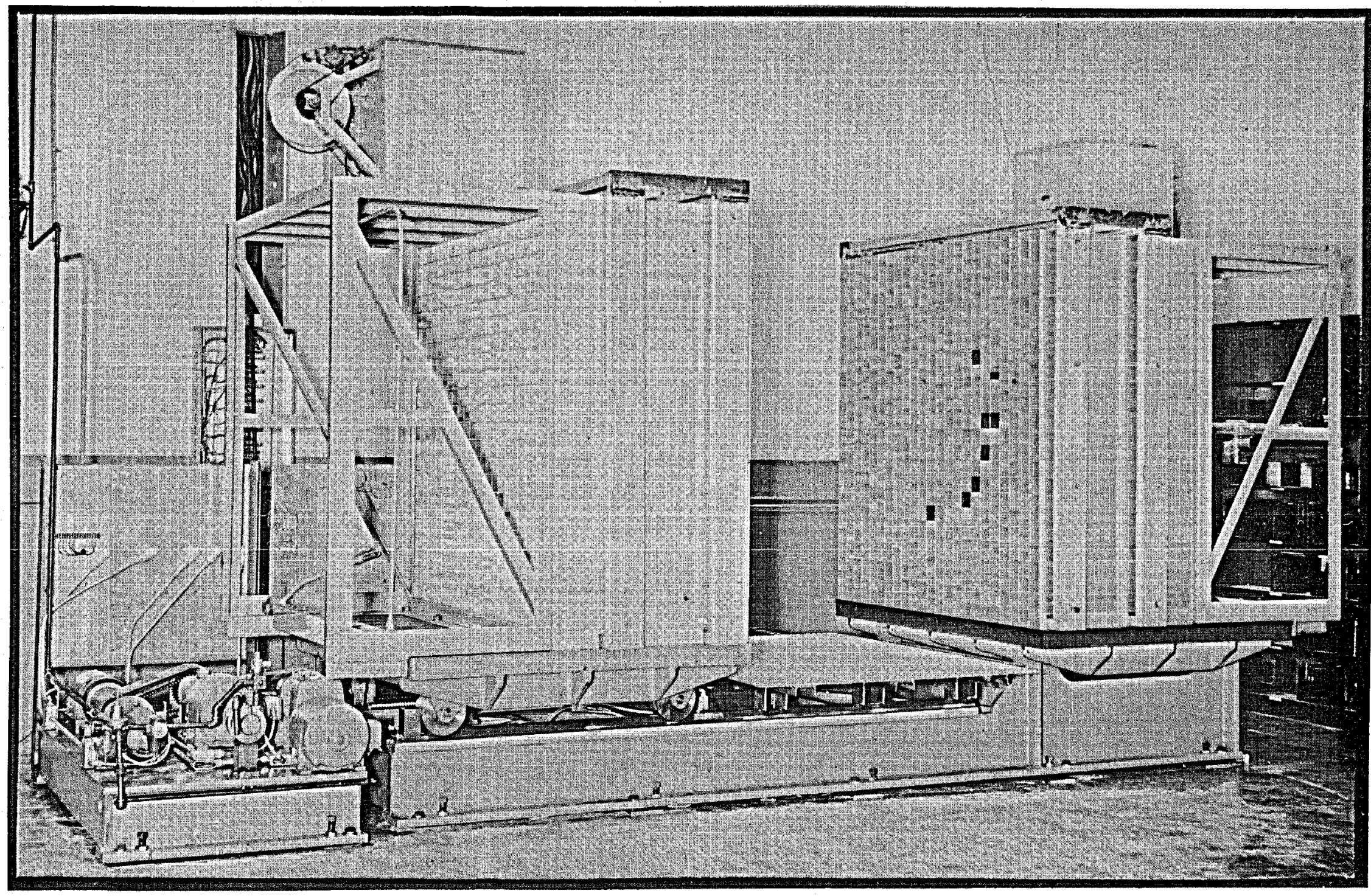




\section{PARTIALLY LOADED ASSEMBLY WITH CONTROL DRIVE MECHANISMS IN PLACE}

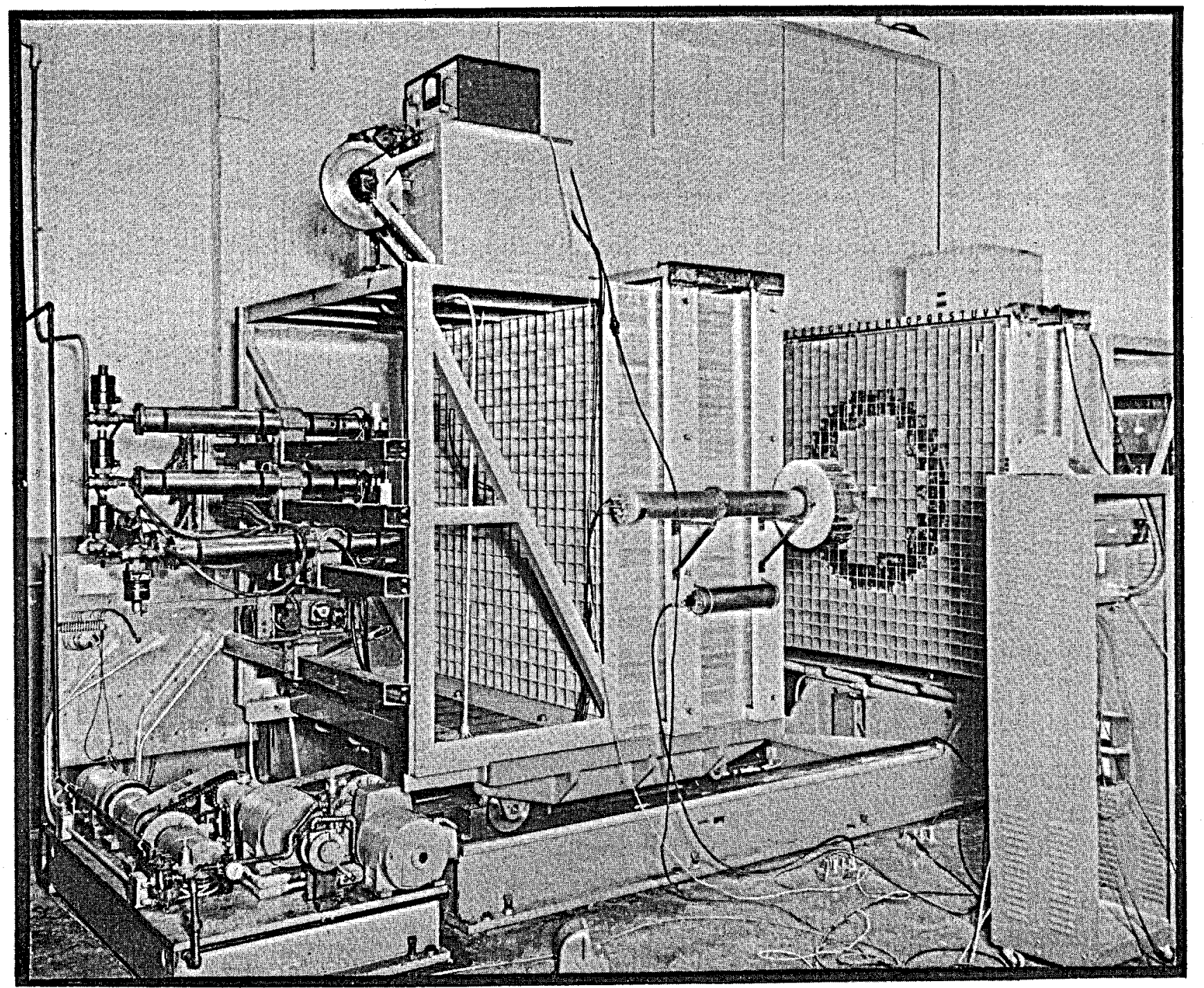




\section{CRITICAL ASSEMBLY FUEL ELEMENTS}

FUEl BOX

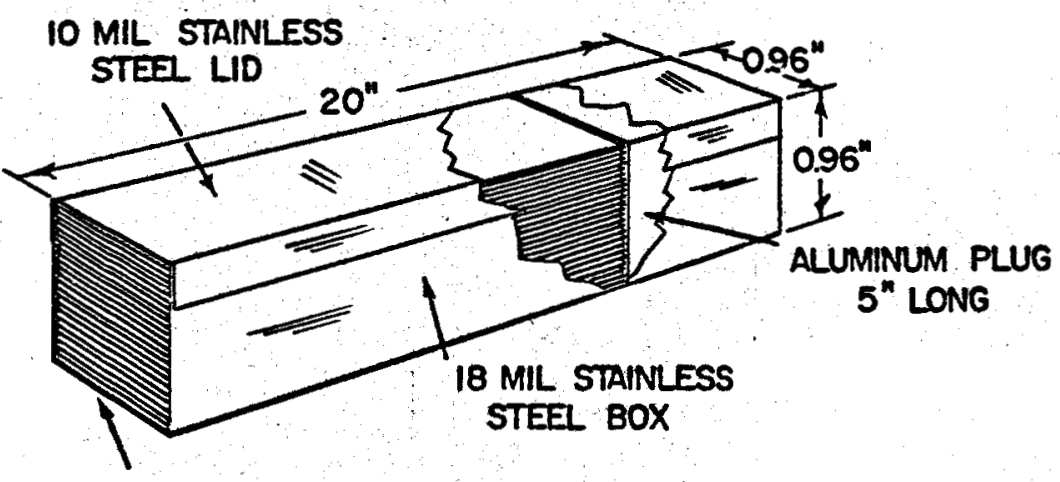

ALTERNATE STRIPS OF ALUMINUM,

CONTROL FUEL BOX

STAINLESS STEEL Q URANIUM

I5 INCHES LONG

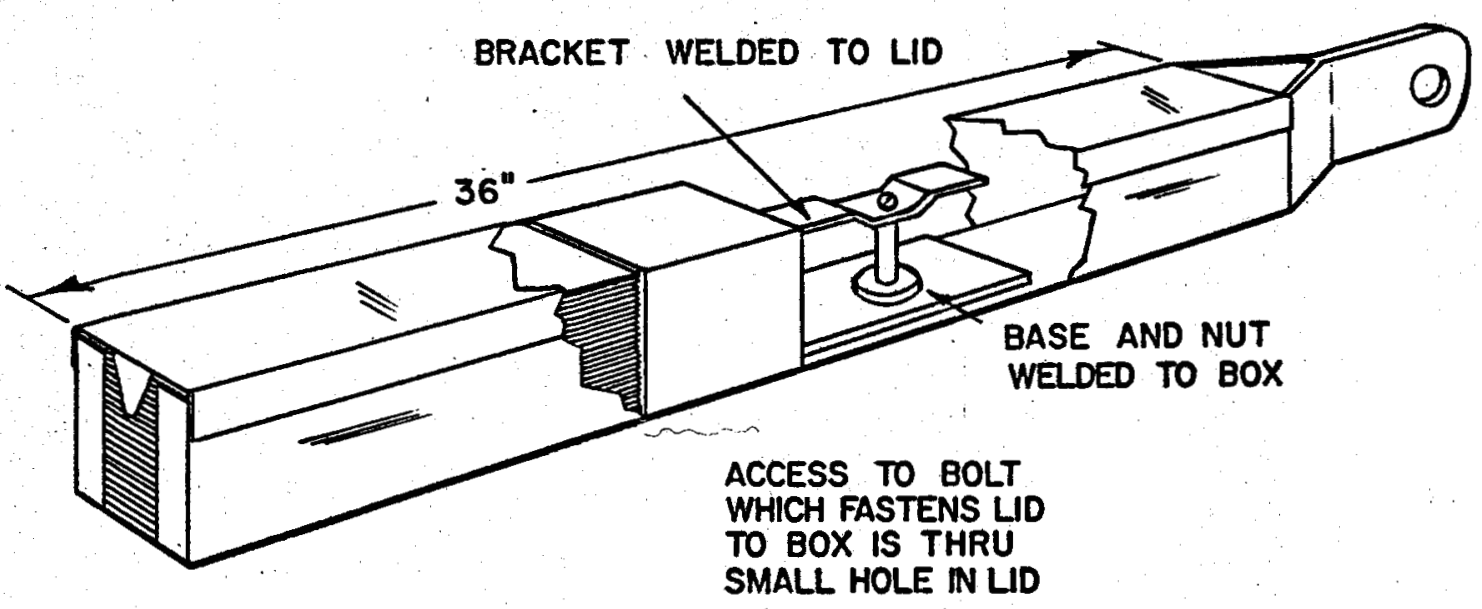

SMALL HOLE IN LID 
The strips of material will occupy only 15 inches of the box length. The remaining 5 inches will be filled with a block of aluminum to mock-up the sodium in the inlet or outlet to the fuel elements. Thus, a 20 -inch long box simulates one-half (15 in.) of a reactor fuel element and the sodium in the reflector immediately above or below it. A small number of boxes will be made with dimensions of 0.48 by 0.96 by 20 inches to provide greater flexibility in duplicating the reactor loadings. A typical loading cross-section is shown in Fig 10.

One hundred twenty-five kilograms of uranium having an enrichment of about 93 percent in the isotope 235 have been rolled into metallic foil to be used as fuel. The foil has been cut into strips of various sizes, as shown in the following table, and most strips have been coated with one-half mil of fluorocarbon plastic.

\section{Metal Strips for Critical Assembly Fuel}

\begin{tabular}{cccc} 
No. strips & Thickness, in. & Width, in. & Length, in. \\
\hline 7320 & 0.004 & 0.882 & 15.0 \\
700 & 0.003 & 0.882 & 15.0 \\
750 & 0.002 & 0.882 & 15.0 \\
150 & 0.001 & 0.882 & 15.0
\end{tabular}

The beryllium moderator is in the form of blocks of various cross-sectional dimensions and lengths to fit into a large variety of core patterns and dimensions and still maintain a minimum of machining and handling. The cross-section dimensions range from 0.48 by 0.48 inches to 0.96 by 1.92 inches and the lengths vary from 2.88 to 7.13 inches. These cross-sections are based on the modulus of the 0.96 by 0.96 inch fuel element. This block size permits locating the fuel elements within one-half of their radius of their design position. A few of the blocks will be cut 0.13 inches undersize. This will permit insertion of special tubes to act as guides for the removable fuel elements used for control. It will also permit stainless steel strips to be inserted to simulate the core and control cylinder shells.

The elements in the simulated control cylinders will be made of stainless steel tubes with outside dimensions of 0.48 by 0.48 by 15 inches long. These tubes will be filled with boron (usually carbide powder) in various densities depending on the design under consideration. These simulated control tubes will fill approximately a 120-degree sector of the simulated control cylinder. Rotation of the cylinder in the reactor will be simulated in the critical assembly by rearranging by hand the position of the boron carbide control elements.

In operating the critical assembly, safety and control will actually be provided by withdrawin certain fuel elements from the assembly. Several fuel elements will be attached to each drive mechanism. The control fuel elements will be placed at convenient locations throughout three of the four quadrants in each half of the assembly. This will permit one quadrant to be free for measurements undisturbed by the controls. These fuel elements (Fig 9) will be made up in a manner similar to the others except that the stainless steel boxes will be 36 inches long with a means at one end for attaching the driving mechanism. The 36-inch length will permit the control element boxes to extend through the grid tubes in which they are located. There will also be provisions to prevent the strips from sliding in either direction and for holding the lid tightly on the box. These provisions will not be made in the other boxes. The control fuel elements will slide in stainless steel tubes which will allow approximately 0.08 inches clearance between the control element and the tube. The guide 
PWAC - 170

FIG 10

SECTION OF TYPICAL LOADING CONFIGURATION

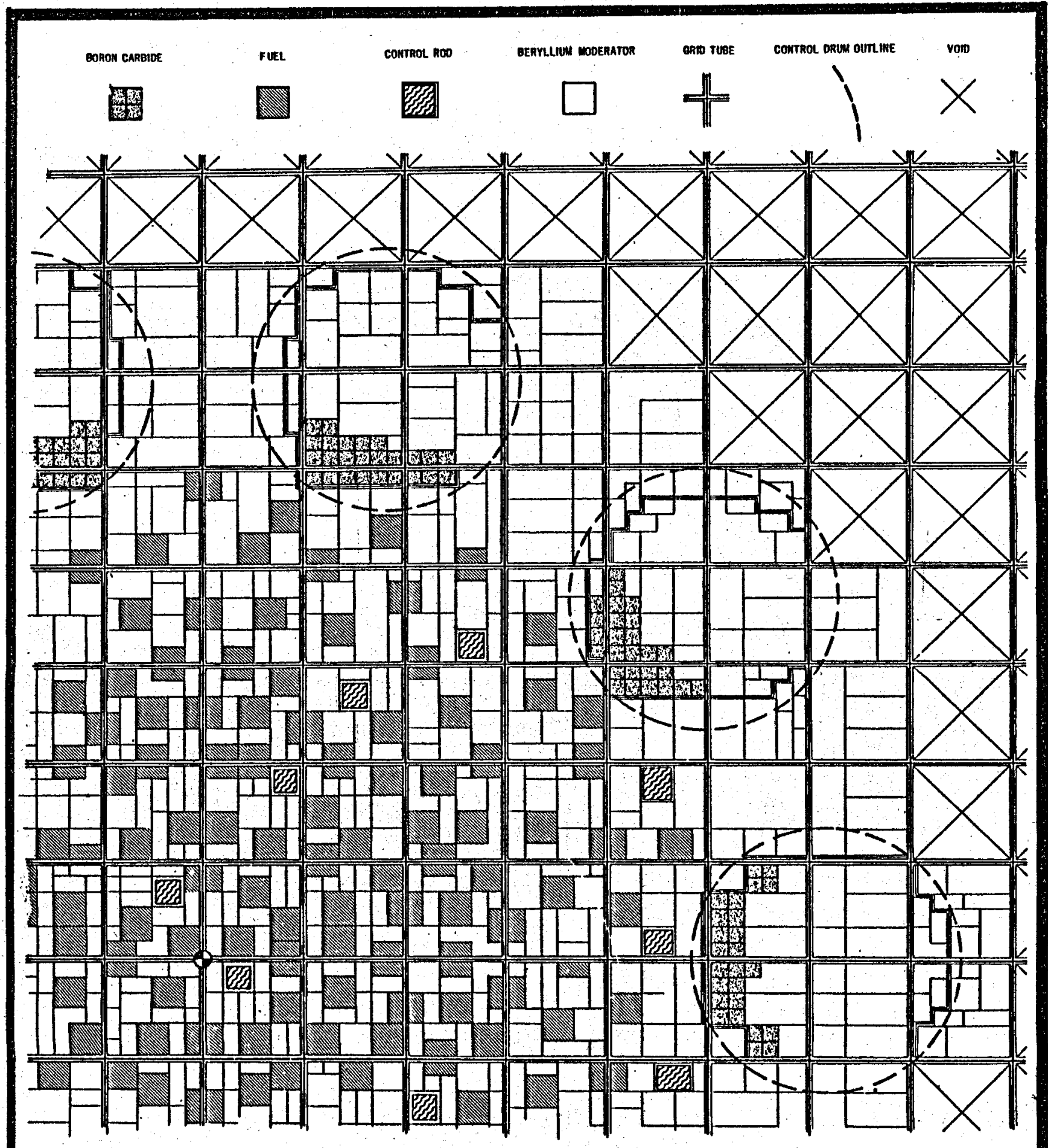


tubes will be attached to the aluminum grid tubes by brackets which will position the guide tube end and will prevent longitudinal motion of the guide tube.

Fig 8 shows a picture of the assembly in a partially completed stage of construction at Battelle. The reflector material and the control cylinders had been loaded into the grid tubes, but the core loading had not yet begun. The safety and control rod drive mechanisms were in position, but had not been connected to the movable fuel elements. The source drive, located on top of the framework, and the detection instrumentation were in place.

3. Assembly Table

The assembly table that will be used to support the test reactor is illustrated in Figs 4 and 7. It is constructed in halves, each of which has a machined flat surface, 5 by 6 feet, with T-slots on 6-inch centers for bolting down parts of the test assembly. One half of the table is attached rigidly to a base fastened to the test cell floor. The other half is supported on four grooved wheels that roll on V-tracks which are also attached rigidly to the base. The halves have a maximum separation of five feet.

The movable table half is driven by a lead-screw through a nut attached to the bottom of this table half. The lead-screw is driven through a slip clutch and a cone gear reducer by four different $220 / 440$ volt, 3-phase motors, only one of which may operate at any time. This motor drive unit is illustrated in Fig 4. Three of these motors are gear-head motors and will be used to bring the halves together. Each of these drives the table at a different speed and is connected to the gear reducer through a magnetic clutch and a chain drive. Camoperated limit switches actuated by the moving table half control the speed changes. The fourth motor is connected directly to the gear reducer and is used to separate the table halves. This motor has a double-ended shaft; an air motor may be attached to provide for separation in event of complete electrical failure.

The schedule of table closure will be a compromise between slowness for reasonable rates of increase of reactivity and speed for convenient operation. The schedule can be modified for different types of assemblies to limit the increase of reactivity to the order of 10 cents per second during the final portion of closure. Changing the schedule will require moving the limit switches or replacing sprockets or the gear-head motors with others having differen gear ratios.

An example of the schedule of table closure is as follows:

a. For a separation of 60 to 18 inches - - the "fast-in" motor driving the movable table half at 24 inches per minute.

b. For a separation of 18 to 2 inches -- the "intermediate-in" motor driving at 6 inches per minute.

c. For a separation of 2 inches or less - the "slow-in" motor driving at $1 / 2$-inch per minute.

d. To separate the halves -- the "safety" motor driving at 40 inches per minute.

The slip clutch between the lead-screw and the driving gears serves two purposes. First, damage to the driving mechanism resulting from obstructions between the halves will be minimized. Second, firm and reproducible table closure can be obtained by driving the halves together until the clutch slips. 
The electrical schematic of the table drive control is given as Fig 11. The "fast-in", "intermediate-in", and "slow-in" motors and their respective clutches are controlled by normally-open relays. After actuation of the proper limit switch, one of these relays may be closed by operation of a switch on the console and thus allow the proper motor and clutch to be activated. The line from the console switch to the relays for each motor passes through two normally-open limit switches in series, which are closed by a cam on the movable table half. The location of these limit switches determines which motor will drive the table at any given location.

The "safety" motor is connected to its power supply through a normally-closed relay and a normally-closed limit switch. The relay is held open by power from the scram circuits; thus, a scram from any source will remove the power from the relay coil allowing the contacts to close, thereby activating the "safety" motor and separating the tables. When the movable half reaches the full separation position, it will open the normally-closed limit switch to remove power from the motor. To insure that this limit switch closes when the table is driven in, the power for the "intermediate-in" and "slow-in" motors also is taken through this switch. Thus, if power is not available to separate the halves, it is not available for bringing them completely together. A phase failure device is present so that the "safety" motor cannot operate in reverse.

The separation of the table halves is shown to hundredths of an inch by two control panel dials, each of which is operated by a different set of selsyns geared to the lead-screw. One dial is calibrated in hundredths of an inch and makes one revolution for each inch of travel; the other dial is calibrated in inches and makes one revolution for the entire 60 inches of travel. The last $1 / 2$-inch of separation is indicated to thousandths of an inch by another control panel dial which is driven by a separate selsyn pair. The transmitting unit of this pair is driven by a rack-and-pinion gear unit mounted in a lower corner of the grid tube structure on the stationary table half and is actuated by the moving half. Two linear differential transformers are coupled to this unit, and their voltage outputs, which should be identical, are used as reference voltages. Two more transformers are located near other corners of the grid structure and their output voltages are compared with the reference voltages. The differences between the reference voltages and the output voltages of the other two transformers are displayed on center-zero voltmeters, indicating whether the inner two faces of the grid structure, and thus of the test reactor, are parallel as they approach each other. In addition, indicator lights show which drive motor is operating. If at any time the indicator lights and the table half separation do not agree with the schedule built into the table drive, operations will be discontinued until the source of the disagreement is found and removed.

\section{Safety and Control Rods}

Safety and control rods will be of the fuel-element-removal type. There will be about 10 independent safety mechanisms. (two of which can be used also for shim) and two or more control rod mechanisms, each driving several fuel elements. Fig 8 illustrates the mounting of the rod mechanisms. Half of each type will be mounted on each table half at opposite ends of the assembly. Initial operation of the assembly at CANEL will utilize safety and control mechanisms constructed by Battelle Memorial Institute.

a. Safety Rod Mechanism

The safety rod mechanism is shown in Fig 12. The rods are "cocked" by introduction of air pressure into the cylinder to compress the double spring. The spring is held in its compressed position by air pressure until receipt of a scram signal which interrupts 


\section{TABLE-DRIVE CONTROL}

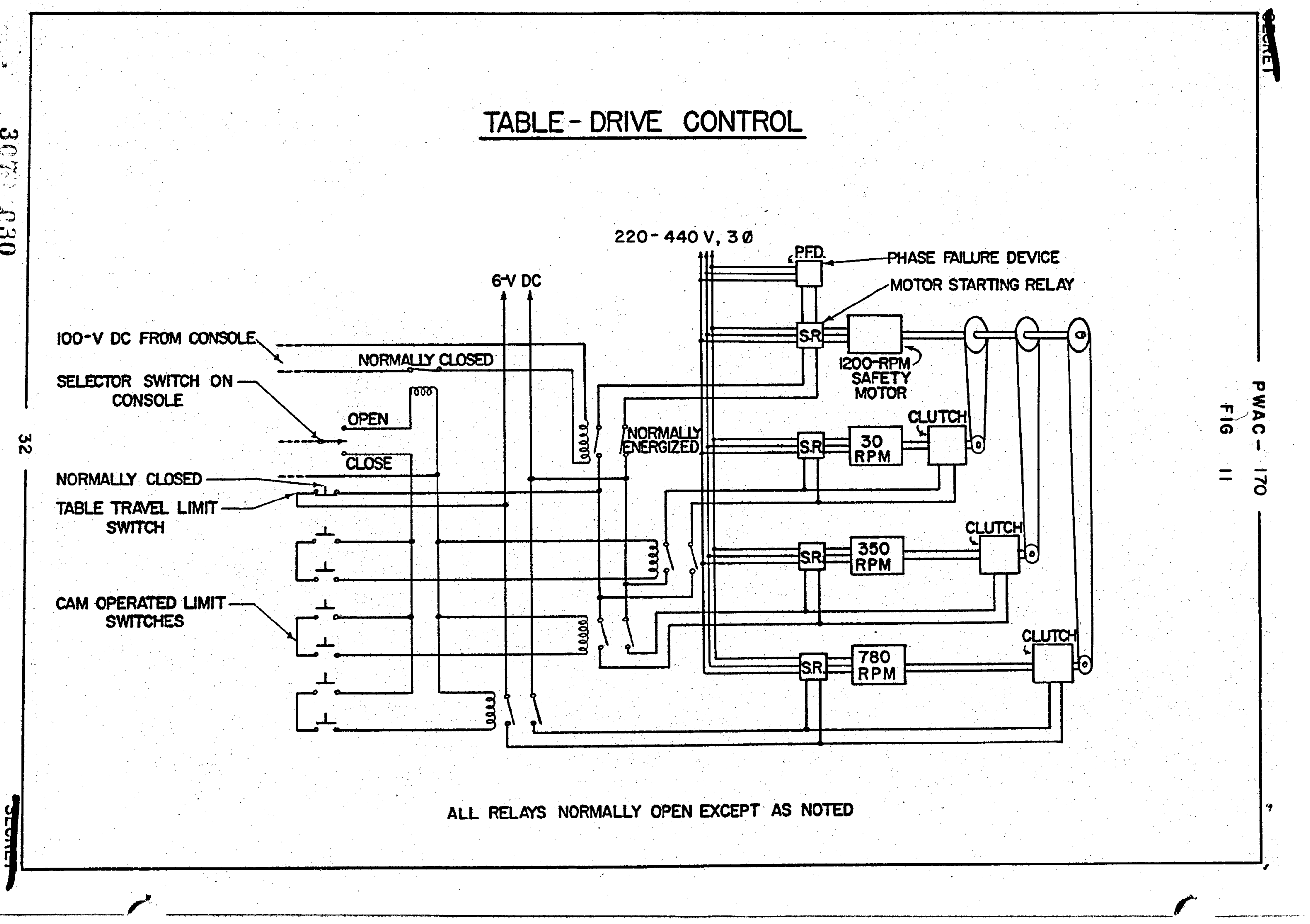




\section{SAFETY ROD DRIVE UNIT}

( SIMPLIFIED )

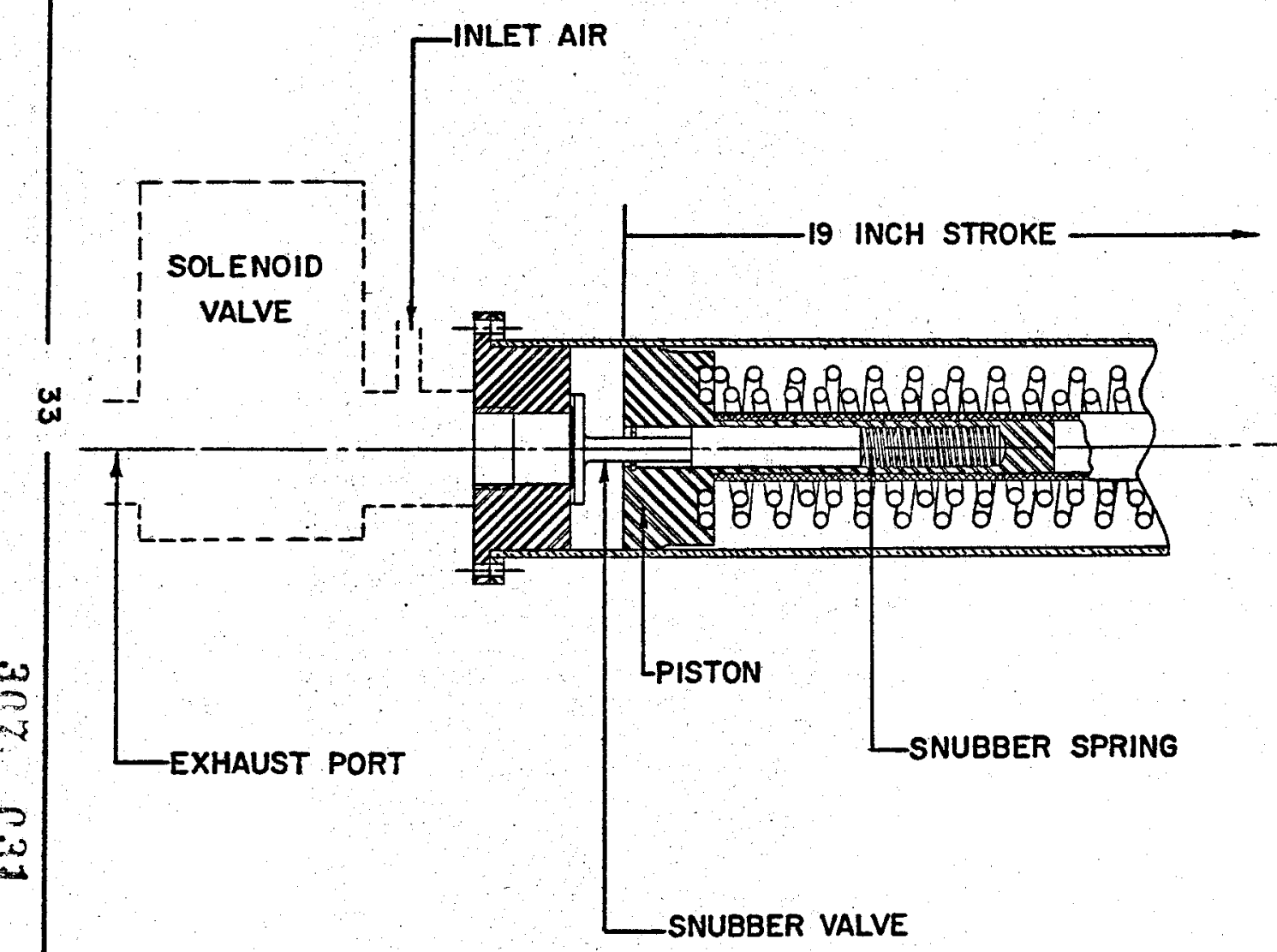

RODS ATTACH HERE

FIRING SPRINGS

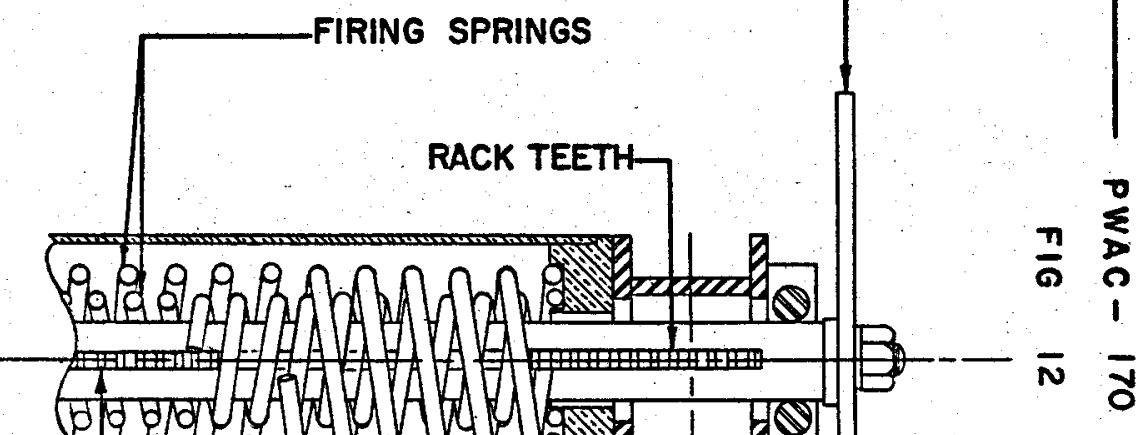

MOUNT FOR SELSYN INDICATOR- 
power to the solenoid valves, allowing the compressed air to vent to the atmosphere. The rods are then free to be driven out of the reactor by the springs. The rods are expected to be out of the core within 350 milliseconds after initiation of a scram signal. Extreme positions of the safety rods will be indicated on the control panel by lights operated by limit switches. In addition, two of the mechanisms will be available for shim. Intermediate positions on these will be indicated by selsyns reading to 0.2 inches.

The schematic of Fig 13 shows the method of operating and controlling the safety rods. In the case of the safeties used for shim, the power supply leads go through a reversing switch, a selector switch, and then through rectifiers to two solenoid-controlled air valves. The polarity of the system determines which solenoid is operative. These valves permit operation in either direction and intermediate positioning. In the remaining safeties, the valve for venting the mechanism is omitted. Thus, these cannot be used for shim purposes. The air for driving the rods goes through a filter, a pressure reducing valve, a lubricator, the controlling solenoid, a ball check valve, and a needle valve for limiting speed of rod travel. A safety valve is included to prevent over-pressure of the system.

Scram action is provided by a normally-open 90 -volt solenoid valve with a large port area. This solenoid valve is energized and held closed for holding the rod mechanisms in "cocked" position. Interruption of the current to the valve allows it to open with subsequent rapid withdrawal of the rods from the reactor. In addition to scram firing, provision is made for firing the rods one at a time or all together, but they cannot be re-cocked until the table halves are fully separated.

To hold the safety rods in the "in" position, a limit switch and separate power supply are provided. These units apply power to the "air in" valve when the rod is at the full "in" position. When the control switch is operated to withdraw one of the two shim rods at normal speed, a relay in the circuit withdraws this holding power from the "air in" solenoid valve to permit the opening of the normal exhaust valve to reduce the air pressure and allow the rods to move.

\section{b. Control Rod Mechanism}

Control rods will be driven by dc shunt motors through a rack-and-pinion drive. Rate of travel will be variable up to a maximum of 24 inches per minute, provided that a change of reactivity of one cent per second is not exceeded. Indication of rod position to 0.01 inches will be provided at the console by selsyn-driven indicators. Extreme positions will be indicated by limit-switch controlled lights.

The electrical circuit for the control rods consists of a 24-volt de supply connected to the motors through a reversing switch, a speed control rheostat, and a selector switch. A separate switch is provided which by-passes the speed control rheostat and energizes all motors, causing all rods to be withdrawn at maximum speed. Limit switches are provided to shut off the motors at extremes of rod travel.

\section{Source}

There will be a neutron source for each half of the reactor. When not in use, each source will be stored in a shielded box mounted on the frame above the assembly. The source will be in a capsule approximately 1 -inch long and 0.25 -inch in diameter, and will be attached to a flexible cable by means of a ball-and-socket connection. In operation, the source will 
PWAC - 170

FIG 13

SAFETY ROD CONTROL SYSTEM

DESIGNATION

ITEM

FCV 1,2

FV 1,$2 ; 4$

FLOW CONTROL NEEDLE VALVES

FV 3,5

FV 6,7

PCV 1

PSV 1,2

$x-1$

SOLENOID VALVES CLOSED WHEN NOT ENERGIZED

SOLENOID VALVES OPEN WHEN NOT ENERGIZED

BALL CHECK VALVES

PRESSURE REDUCER

$x-2$

SAFETY VALVES

FILTER

LUBRICATOR

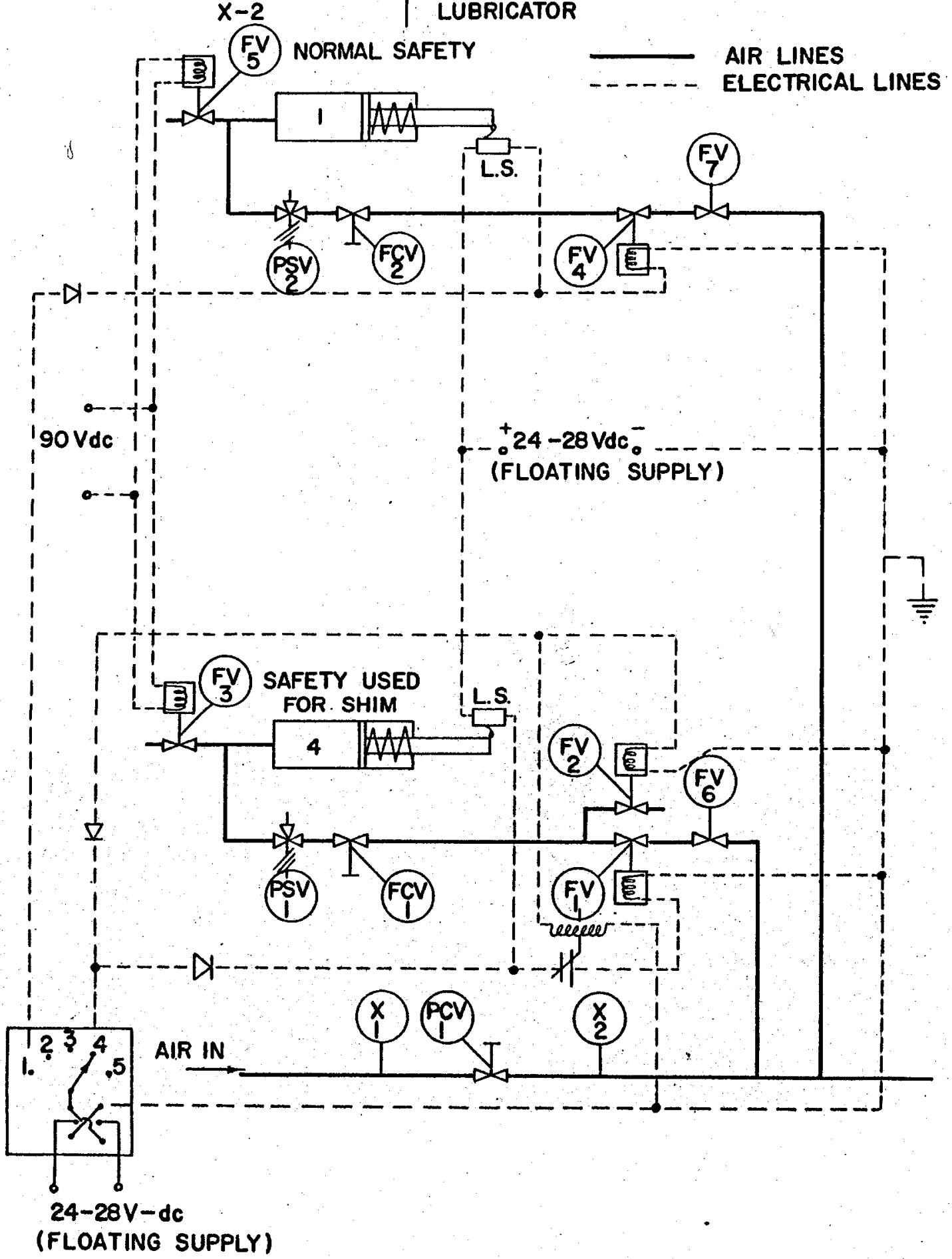


be driven on the end of the cable from the box down through a length of steel tubing and into the reactor (Figs 6, 7, and 8). The source will enter from the end reflector, with the tubing penetrating the core about 8 inches.

The driving mechanism for the source will be attached to one side of the shielded box. The source cable will be wound and unwound from a drum, while, at the same time, a gear engaging a wire wound spirally on the cable drives it along through the box and tube. $A$ suitably geared-down dc motor will provide the necessary driving power for both the gear and drum.

Roller-actuated microswitches operating from the side of the cable drum will prevent overdriving of the source in either direction and will indicate source "full in" or "full out". A tooth gear driven by the spiral wire on the source cable can be connected to one of a pair of selsyns serving to indicate source position if desired. Associated indicators and controls will be provided on the source control panel on the console.

6. Special Characteristics of the Critical Assembly

The composition of the critical assembly will change from time to time as variations of the design are mocked-up; therefore, the physical characteristics of the assembly will vary somewhat. However, the probable composition of the first assembly can be given and the calculated parameters which are important in assessing the hazards associated with it. Future changes in the composition should not change these parameters significantly. Composition of the first assembly is given in the following table.

\section{Critical Assembly Composition}

Material

$\mathrm{Be}$

Al

Stainless Steel

$\mathbf{U}$

$\mathrm{Be}$

Al

$\mathrm{B}_{4} \mathrm{C}$

Stainless Steel

\section{Volume, percent}

\section{Core Region}

\section{Reflector Region}

Other calculated parameters are

Neutron generation time

$$
\begin{aligned}
& =6 \times 10^{-6} \mathrm{sec} \text { clean } \\
& =6.5 \times 10^{-6} \mathrm{sec} \text { at end of life }
\end{aligned}
$$

Temperature coefficients

$$
\begin{aligned}
& \delta \mathrm{K} / \delta \mathrm{T}=-2 \times 10^{-8} / \mathrm{deg} \mathrm{F} \text { due to change in thermal base } \\
& \delta \mathrm{K} / \delta \mathrm{T}=-9 \times 10^{-6} / \mathrm{deg} \mathrm{F} \text { due to expansion, based on expansion coefficlent of }
\end{aligned}
$$
stainless steel

Mean neutron energy for producing fission $=240 \mathrm{ev}$. 
The temperature coefficient due to core expansion was calculated for the power reactor for which these studies are being made. Therefore, the stainless steel expansion coefficient was used. The coefficient for the critical assembly is more likely to be dependent on the aluminum grid tubes expansion and is therefore likely to be larger. However; these coefficients are not important in normal operation since the reactor is not producing significant amounts of heat. In an accident, the temperature rise is likely to be so rapid that there is little heat-transfer from the uranium to other materials. In this case only the Doppler coefficient would be important. The Doppler coefficient for $\mathrm{U}^{235}$ is not known with sufficient accuracy at the present time to be used in calculations with any degree of certainty.

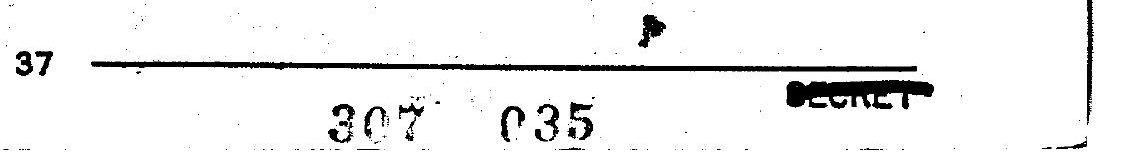




\section{INSTRUMENTATION AND CONTROLS}

\section{General}

Consoles are designed so that operating and safety switches and lights, position indicators, and key power-level and period meters and recorders will be grouped in front of the operator. Auxiliary counting and recording equipment will be to one side, as will any special installation of secondary controls. In designing the consoles, consideration will be given to ease of reading of indicators and recorders and to simplicity and naturalness of operating the controls. Switches will be arranged so that the "up" position corresponds to an increase in reactivity and must be maintained by holding against spring pressure. "Down" position will correspond to decrease in reactivity and in some cases will stay without holding. A red light will indicate a potentially hazardous condition and a green light a safer condition. The consoles will be arranged to allow operation while sitting.

Sound communication between control room and cell will be by two-way intercom system, separate for each cell.

\section{Operational and Control Instrumentation}

The operational instrumentation for the critical assembly is shown in block diagram form in Fig 14.

All sensing elements, such as ion chambers, proportional counters, etc., used for control and safety purposes, will be mounted on or adjacent to the assembly and will have sufficient sensitivity to detect neutrons resulting from the presence of the source in its operating position with the assembly fully separated. Most of the sensing elements will be placed so that they are not exposed directly to the source when the table halves are apart. All sensing elements and their associated circuitry, except some auxiliary gamma monitors and low-range proportional counters, will have sufficient range to operate from pre-startup background to above any operating levels.

For multiplication experiments and startups, there will be four scaler channels operating from BF3 proportional counters and/or fission chambers. The BF3 counters and fission chambers will be interchanged as desired according to experimental requirements. One channel will also incorporate a log count rate and period circuit as an operator convenience, and the other three will have additional audio outputs. All four channels will respond to multiplication of the source.

Three boron-lined ion chambers will feed linear dc amplifiers and associated recorders. These amplifiers feed independent level signals to the safety circuits, and will respond to source multiplication. One amplifier may incorporate a differentiator circuit and recorder to obtain rate of drift information as an aid to approaching steady level. The recorder on another amplifier may incorporate an optional zero suppression as an aid in detecting slow level drifts:

Two boron-lined ion chambers will feed logarithmic dc amplifiers and their period circuits. One log level recorder and one period recorder will be used in the channel desired, the other channel being used as an operating spare. Both period channels will supply signals to the safety circuits. These logarithmic channels will respond to source multiplication.

Gamma level will be detected by a photomultiplier scintillation head, a logarithmic circuit, and recorder. This circuit will also feed a level signal to the safety circuits and will indicate down to normal background. 


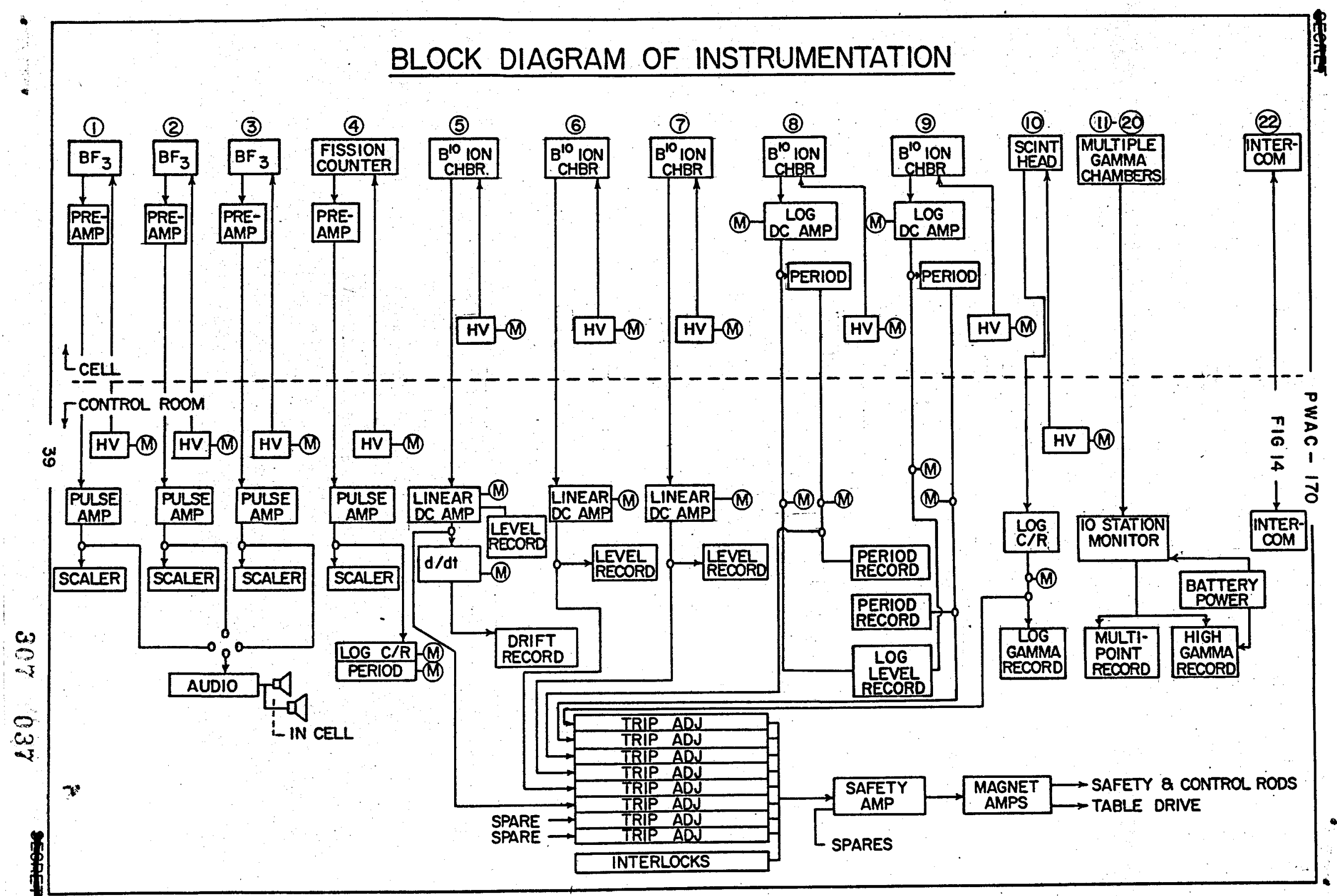


Additional gamma monitoring will be available in several channels of a multi-channel ion chamber monitor. Other channels of this instrument will monitor the control rooms, vaults, roof, filters, etc., and the associated multipoint recorder will be in view of the critical assembly operator. The multi-channel monitor and one or more of its recorders operate through a small independent emergency power supply such that, in event of total building power failure, a record of shutdown may be obtained. All of the essential circuit units, amplifiers, etc., as used in the above control, safety, and information channels will be of types and models proven in other similar installations.

\section{Safety Circuits}

The four level and two period signals enter the safety circuits as directly observed high: level signals. Variable attenuators permit adjustment of trip level. The safety amplifier acts as a mixer and auction circuit, the output of which operates the magnet amplifier. The magnet amplifier is the source of power to the solenoid valves for the rods or to normallyopen relays carrying power to the solenoid valves. Loss of this power will also cause the table halves to drive apart. Several interlocks will also operate the safety circuit. The design of the entire safety circuit is such that, insofar as possible, component failure will cause scram. Where this is not possible, duplicate circuitry will be used. 


\section{E. TYPES OF EXPERIMENTS}

The discussion below lists the types of studies to be performed with this critical assembly. The experiments mentioned are not listed in any specific order. The order in which the experiments are performed will depend first on the need for particular information and second on the desire to minimize the time required for the overall program.

\section{Critical Mass Studies}

The $\mathrm{U}^{235}$ loading will be determined for the proposed reactor design and for possible modifications in this design. Modifications which will effect the critical mass are the fuel arrangement, the core size, the number, size, and composition of control cylinders, the materials ratios in the core, and the reflector thickness.

\section{Control Evaluation}

Attempts will be made to measure:

a. The reactivity worth of all the control cylinders,

b. The subcriticality of the reactor at the beginning of life with all the cylinders turned in,

c. The worth of one cylinder as a function of position for various positions of the other cylinders,

d. The effects of changes in size, number, and composition of the control cylinders.

These quantities will be measured in terms of reactivity change for various percent fuel burn-ups in the core. For the burn-up studies, uranium will be removed and poisons yet to be selected added to simulate fission product poisons. Some of the measurements will be repeated for end-of-life conditions and also for several intermediate-life conditions of the core.

\section{Power and Flux Distribution Measurements}

The power production as a function of position will be measured throughout the core volume and in detail through specific fuel elements. Power distribution measurements will also be made near control cylinders in their normal operating positions and near cylinders which are out of position with respect to the remaining cylinders. These measurements will also be made for core configurations corresponding to various core lifetimes.

The techniques for making power distribution measurements will be primarily that of measuring fission product activity. This may be done by counting uranium foils which have been activated in the reactor or by counting the fission products on aluminum catcher foils placed next to some uncoated uranium strips.

In making flux measurements, various materials may be activated, such as manganese, indium, or gold. These folls as well as the uranium folls may be irradiated bare and cadmium-covered. 
4. Reactivity Coefficients

The effect on reactivity of small additions of material representing fission product poisons, structure, coolants, additional fuel and the like can be evaluated by noting the change in the position of the calibrated control rods or by resulting periods.

5. Optimization of Design

Experiments may be made to optimize the core design. Such changes as variations in the fuel element arrangement and in control cylinder geometry may be investigated. The objectives will be to maintain as uniform a power distribution as possible during the entire operating lifetime and under all operating conditions. This must be accomplished while maintaining sufficient reactivity control. This type of experiment will repeat measurements of the type described above with modified parameters.

6. Operational Checks

Certain experiments will be performed to check the operation and safety of the critical assembly itself. Also, tests will be made to determine the reliability of the results obtained with the assembly. Such experiments as measuring the reactivity as a function of table separation, the worth of safety and control rods, the uniformity of fuel elements, and the temperature coefficient of the critical assembly will be made. The uniformity of the fuel elements might possibly be checked by substituting a fuel element designated as a standard for other fuel elements in various locations in the reactor. The temperature coefficient will be estimated by allowing the room temperature to change, thus changing the reactor temperature over a small range. The change in reactivity with all other factors remaining constant will be measured.

7. Other Experiments

Other experiments will include measurement of gamma ray energy dissipation rate; leakage from the assembly, substitution of an "actual" fuel element of power-reactor type, and possibly activation of reactor materials. 


\section{F. PLAN OF - NORMAL OPERATION}

\section{Handling of Fissionable Material}

Fissionable material will be stored in the vaults, which will be operated as accountability sub-stations. A staff member will have responsibility for keeping records on the location of this material. He and his appointed assistants will be the only persons normally having access to a storage vault. Each piece or container of fissionable material will be labeled, and transfers will be recorded when material leaves or enters the storage vault. Amounts will be marked on loading records when material is put into or removed from a critical assembly. Material that is in a critical assembly will ordinarily be left there overnight since the test cells will be adequately secured.

\section{General Operation of a Critical Assembly}

Before assembling, changing, or operating a reactor assembly, the operating crew must agree unanimously that the planned procedure will be safe. Judgments should be based on analysis or extrapolation of past experience with related assemblies. If major changes are contemplated, the head of operations must also agree.

A critical assembly will normally have a three to six-man crew. At least two operators must be present for any operation and three for non-routine operations. Depending on the nature of test, one or more of those present must be senior personnel selected on the basis of their experience, ability, and temperament.

The assembly will not be operated when background distractions are considered to constitute a hazard.

Before startup on any, day, the response of all instruments will be checked against a portable source of known strength. Trip levels will be checked with cocked safeties by scramming with the portable source.

Before startup of any run the test cell will be cleared of people, the access doors closed, and the warning signs changed to indicate "reactor on". Instruments will be turned on, one or both sources inserted in the critical assembly, and the response of all instruments noted. All linear neutron detectors must respond to the presence of the sources. The proportional counter channels will be audible.

Normal approach to criticality will then proceed as follows: Safety rods will be cocked, one at a time. Control rods will be put in the least reactive position. The reactor will then be brought to criticality by bringing the halves together and inserting the control elements in a series of increments. The period will normally be limited to a minimum of 30 seconds. The source will be removed and the control rods adjusted to bring the reactor to the desired power level. Power level will ordinarily be about one watt and occasionally on the order of ten watts. During the approach to criticality and desired power, the trip level will be increased to keep a factor of from two to ten between trip level and power level. Changes in multiplication and power level will be observed from meters and recorders as noted earlier.

Normal shutdown of the assembly will be accomplished by withdrawing the control rods simultaneously if desired, and separating the table halves. After several minutes, residual radioactivity will have decayed sufficiently to allow working directly with the reactor components. Activity levels will be checked each time with portable survey meters. 
Normal loading changes will be limited to considerably less than the value of the safety system. Major changes will require following a procedure for initial approach to criticality.

A logbook will be maintained for each critical assembly. It will contain records of instrument checks, loading changes, procedures peculiar to a particular experiment, control settings, instrument readings, and any other information pertinent to future evaluation of procedures and data.

\section{Initial Approach to Criticality}

The initial approach to criticality with a new assembly or one involving major rearrangement will start with assembly of the pieces omitting the uranium or even providing a filler in place of the fuel material. Then neutron sources will be inserted and instrument levels read with the tables together and control rods inserted. Next, a small fraction of the expected critical mass will be inserted (with the tables apart) and the source multiplication measured as above. This will continue with conservative fuel additions until criticality is reached. A rule frequently applicable to the addition of fuel in this type of assembly is to limit the next increment of fuel to half the difference between the existing mass and the critical mass obtained from extrapolating a plot of the inverse of source multiplication versus mass to zero, but with an absolute limit on the amount added. Fuel addition will by hand observing the following precautions:

a. A loading chart will be marked to indicate the status of the assembly.

b. At least one linear neutron detector and one proportional counter having audio output shall be operating and tended by a member of the operating crew.

c. A source will be present in the assembly and the safeties will be cocked whenever feasible.

d. Communication between the test cell and the control room will be maintained, and information concerning sudden or erratic change in neutron level will be relayed.

When source multiplication reaches a considerable value (say 10 ) and again at a very low power level after reaching criticality, the effectiveness of the controls and safeties will be tested. 


\section{G. SAFETY MECHANISMS}

The proposed critical assembly is not inherently safe against power surges; therefore, considerable emphasis has been placed on designing the facility and equipment to minimize the possibility of accident either from malfunctioning of equipment or from operator error. The principal features incorporated to make operation of the assembly safe are described below.

\section{Table Separation}

The assembly will be split into widely separated halves during periods of loading, modification or idleness, and the chance of reaching criticality in one half will be remote. Table closure will be accomplished by motors having definite top speeds and connected to give decreasing speed of table motion as the tables come together. The lowest speed of table closure will start with the tables separated sufficiently to allow for a considerable amount of excess reactivity, and the lowest speed will be selected to limit increase of reactivity to the order of 10 cents per second.

The final closing speed of the tables will be $1 / 2$-inch per minute, resulting in an estimated reactivity change of 4 cents per second. The tables will always separate at 40 inches per minute, resulting in $\mathbf{8 0}$ times as rapid reactivity change for the shutting-down procedure.

An alternate electrical supply system, and possibly an air-powered drive system, will be provided so that in event of failure of purchased electrical power, the tables can be separated. Personnel, therefore, will not have to enter the assembly room with the reactor halves assembled.

\section{Safety Rods}

The minimum reactivity available in the safety rods will be about three dollars. The rods are expected to remove three-quarters of this amount of reactivity from the assembly within 350 milliseconds atter initiation or a scram signal. All but two of the ten to twelve mechanisms will be fully cocked at all times during operation. The remaining two will be movable for shim purposes. Inlet air valves on these shim rods will be adjusted to prevent the introduction of reactivity at a rate greater than one cent per second. The console selector switch will be designed to prevent the inward motion of more than one mechanism at a time. Provision will be made for firing the safeties singly or all together independently of scram, but to make the reactor critical again after firing one or more rods, interlocks require that the table halves be separated and a full startup procedure be conducted. 'The safety rods will be tested for proper operation before each day's startup. This procedure, with careful maintenance, will insure that the failure of more than one safety mechanism is extremely unlikely.

\section{Control Rods}

There is expected to be approximately 50 cents worth of reactivity divided among control mechanisms. This value may be increased if occasion demands, but will never be allowed to exceed the worth of the safeties. Mechanism speed will be adjusted so that the maximum rate of increase of reactivity does not exceed one cent per second. The adjustment for setting the maximum speed will not be available to the operator. The console control rod selector switch wili be designed so that only one mechanism may be moved inward at a time.

\section{Scram System}

The reactor can be scrammed manually, by instruments, by interlock, or by power failure. 
Manual scramming will be by means of scram buttons or pull-cords to be located at convenient points in the control room and test cell. Instrument scram will occur if neutron flux or gamma radiation levels detected by the instruments exceed the preset trip levels. Interlock scrams will be caused during operation by.opening of test cell doors. Any interruption in power to the controls or instrumentation will result in scram.

When scram of the assembly is initiated by instruments or manual action, the following events will take place:

a. The safety rods will be released to shoot by spring force to their positions of least reactivity.

b. The table halves will separate at maximum rate, driven by a motor which will have emergency power available.

c. The dampers in air ducts to and from the test cell will close.

d. The ventilation system for the test cell will turn off.

e. The red "reactor on" lights in and around the bullding and at the access roads will flash.

f. Horn alarms in and around building will sound.

Power failure will result in the occurrence of all above events except $e_{\text {. and } f \text {. Interlock }}$ scrams will cause only events $a$. and $b$. above.

After initiation of a scram, a return to normal operating conditions can be made only by resetting a lock-in relay for the unit in which the trip occurred.

5. Mechanisms to Prevent Unsafe Operation

Monitoring instruments will be provided to keep the operators informed of gamma radiation level and of neutron density and its rate of change over the whole range of operation and will initiate scram if these quantities exceed preset values. The detectors are placed to see primarily neutrons multiplied by the assembly. Counter-type monitors provide audible as well as visual indication of increased multiplication.

A neutron source will be inserted into the assembly before startup to provide an initial neutron level sufficient to give quick response in multiplication and to show on detecting instruments.

Interlocks that will be active during normal operation of the assembly are listed below.

a. Interlocks prevent the moving of table halves together until:

1. Cell access doors are closed.

2. Internal and external test cell signs are changed to "on".

3. Critical assembly source is "in".

4. Safety rods are cocked.

5. Control rods are in the least reactive position.

Lights or position Indicators will notify the operator which of these conditions have been satisfied. 
b. Interlocks for control rod operation:

1. Selector switch allows only individual control (or shim) rod operation in increasing or decreasing reactivity.

2. Collective switch allows simultaneous operation of all control rods for decreasing reactivity only.

c. Interlocks for safety rod operation:

1. Selector switch allows only individual cocking of the rods.

2. Interlock on the air supply prohibits cocking of safety rods when table halves are not fully apart.

d. Interlocks initiating scram, if during operation any of the following occur:

1. Control power is interrupted.

2. Cell access doors are opened.

Since interlocks must be overruled for maintenance and periodic checks, provision will be made for by-passing them on the front of the console so that the operator will always know which are in effect.

A pressure senser in each test cell will cause dampers in the cell air ducts to close and the ventilation equipment for the cell to turn off whenever an appreciable pressure rise occurs. 


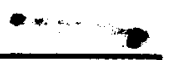




\section{HAZARDS AND ACCIDENTS}

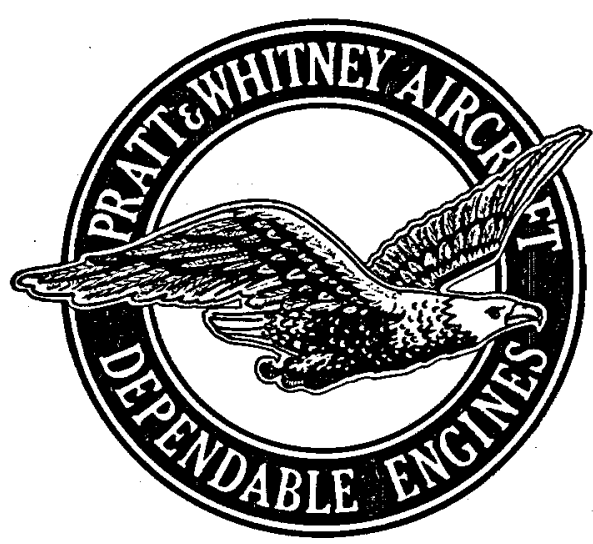

HAZARDS SUMMARY REPORT ON CRITICAL EXPERIMENT PROGRAM NO. 1 AT CANEL MAY 24, 1957 


\section{A. HAZARDS FROM NORMAL OPERATION}

The hazards resulting from normal operation are not great. These hazards include the possibility of contamination by airborne fission products, since the reactor fuel will be uranium metal strips, and the hazard due to radiation through the assembly room walls and celling. The fast neutron intensity outside the assembly room will be particularly important, since this reactor has an intermediate energy spectrum with a high uranium loading and a high leakage. However, this high neutron leakage will allow operations at extremely low power, since it is the leakage neutrons which are detected in the neutron-sensitive detectors.

\section{Fission Products}

It is estimated that less than 0.3 percent of the fission products will escape from the uranium fuel. This estimate was obtained in the following manner. The uranium fuel will be coated with a teflon-type coating, 0.0002-inch thick, which is approximately 1.5 $\mathrm{mg}$ per $\mathrm{cm}^{2}$. If the fission products are assumed to have an average range of $3.2 \mathrm{mg}$ per $\mathrm{cm}^{2}$, the depth from which fission products may escape from uranium will then be the difference in these two values, or $1.7 \mathrm{mg}$ per $\mathrm{cm}^{2}$. This density corresponds to approximately $0.04 \mathrm{mil}$ of uranium. Therefore, of the fission products traveling perpendicular to the surface, only 1 percent escape from the 4.0 mil thick foll. Since fission products will be traveling in all directions, an estimate could be made of the number escaping by an integration process. However, an estimate sufficiently accurate for these purposes can be made by considering that there are six coordinate directions in which fission products can go and only one of these is out from the surface. Therefore, only $1 / 6$ of those fission products originating close enough to the surface to escape will actually escape. This factor must then be multiplied by 2 since there are two surfaces to each uranium strip. These three factors multiplied together lead to 0.3 percent total fission product escape.

The uranium strips will be tightly packed with stainless steel and aluminum strips in stainless steel boxes. There will be no airflow over these strips. Therefore, any fission products escaping from the uranium strips will have a high probability of being captured in the stainless steel or aluminum strips. Only an insignificant number will be stopped in the air.

When fuel bundles are torn down for storage or major rebuilding, smear tests will be taken to determine if there is any contamination which can be picked up and transferred. Filters provided in the normal exhaust systems of the cells and assembly rooms will catch most of any particulate matter in the air.

2. Radiation

Because of the nature of this reactor, it is expected that the fast neutron will constitute the major part of the radiation hazard to personnel. A conservative estimate of the fast neutron intensity outside the test cell was made using an attenuation factor through concrete for fast neutrons, and assuming that neutrons are either absorbed in a fission process or are lost by leakage out of the reactor. This assumption is very conservative since neutrons will be absorbed in the other materials in the core, and will be degraded in energy in passing through the reflector.

Also included was the dose due to radiation passing through the roof of the test cell and then being scattered downward by the air. The calculation treated only single scattering but ignored air attenuation.

Similar calculations were made for gamma radiation. 
The calculations indicate that one watt continuous operation on a 40-hour-per-week basis will lead to a dose which is, by more than a factor of $10^{3}$, below tolerance outside the cell walls.

Since the assembly will normally be operated at about one watt and seldom as high as ten watts, the directed radiation hazard in the building is quite negligible. In fact, the assembly could be run as high as one kilowatt without causing a radiation hazard.

Surveys about the building, both inside and out, will be made with portable instruments to determine the radiation pattern for each new system, and fixed monitors will be rum continuously during reactor operation. 


\section{B. POTENTIAL HAZARDS AND COUNTERMEASURES}

Hazardous situations in the critical experiments could occur as a result of improper action by personnel, malfunction of equipment, possible autocatalytic characteristics, or catastrophes such as fire, flood, or earthquake. Two or more such potentially dangerous factors would have to occur in conjunction in order to cause a damaging accident.

\section{Improper Actions by Personnel}

In the normal course of putting together and modifying a critical assembly, errors in loading might be made which would result in supercriticality. This could occur either during loading or with the halves coming together rapidly while the gap between is still large. Protection against this contingency is established by:

a. Loading the assembly in halves so that the error to reach criticality would have to be very great.

b. Having a written plan for the loading changes.

c. Maintaining a loading diagram and other records of loading changes.

d. Checking the amount of fissionable material leaving the storage vault.

e. Having the reactor materials marked where necessary to ensure identification.

f. Having instrumentation turned on so that multiplication will be indicated at the console and audibly in the cell.

g. Having safety rods cocked and source inserted when feasible.

Insertion of measuring devices or the presence of people near the reactor could result in appreciable changes in reactivity. These effects will be estimated prior to initial operation or determined experimentally in small increments.

Removing poisons by hand could cause rapid increases in reactivity. If the value of such poisons is sufficiently great to involve hazard, arrangements will be made to prevent mechanically rapid withdrawal of the poison.

Control room personnel can inadvertently operate the wrong control, or follow incorrect sequence, make mistakes in calculating necessary changes, ignore or fail to see warning signals, or fail to take corrective action. Chances of such improper actions are reduced by designing the control console for easy reading, natural control motions, and repeated indication of neutron levels and rates of change. To counteract improper actions, a number of interlocks are provided, as described earlier, which will require that steps such as cocking safeties, inserting a source, etc., be done before the halves can be brought together. If the reactor becomes supercritical before expected or noticed by the operators, monitoring circuits will initiate scram before dangerous power levels are reached. Violation of some of the interlocks will also cause scram as described above.

Another type of incorrect action by personnel is improper altering of the equipment either through error or by intention for the sake of "expediency". Most of the equipment will be arranged so that it is either difficult to change or requires deliberate action for access. For example, changing the table drive requires changing motors, gears with a gearbox, sprockets or lead-screw, or moving the limit switches. Instrumentation and control 
equipment, relays, connectors, etc., in the control room will be enclosed in cabinets. Thus, there is small chance of altering equipment without having knowingly worked on it. Trial of the components involved will be made under safe conditions to check the results of any servicing or planned alteration. Routine preoperational checks will also disclose most faulty operations. By-passing of interlocks is made obvious by the arrangement on the console described earlier. No physical blocks exist, however, that will prevent all possible intentional improper alterations or by-passing of safety procedures.

To reduce the risk of personnel error, emphasis will be placed on the selection of personnel and on safe practices; suitable working conditions will be provided to minimize further chance of human error. Preliminary reports will usually be written for safetycheck before an experiment. Selected senior personnel will be primarily responsible for judging and maintaining safety. A crew of two or more operators, including senior personnel, must be present for operation. Unanimous agreement among the operating crew must exist prior to assembling, changing, or operating a critical assembly. Proper working conditions and fitness of per sonnel must be established before operations proceed. Check lists will be provided to assist in checking-out equipment.

Willful intent by personnel to cause damage, or sabotage, must also be considered. Any of the above-described inadvertent actions are readily within the scope of sabotage. In addition, a saboteur might create a loading of high reactivity by adding fuel or reflector, removing poisons, or re-arrangeing parts; or alter the table-drive system to give excessive speed. He might jam or by-pass the safety rod mechantsms so as to prevent firing of the safety rods. He might by-pass the scram circuit or alter instruments to indicate falsely low power levels. A saboteur also might pre-arrange to expel poison rapidly with explosives after the assembly is critical. Finally, there will be sufficient fissionable material in the reactor or in the vault to permit the formation of a supercritical assembly of some other type, using other mechanisms.

Sabotage sufficient to cause a serious disaster, however, is considered remote. The Nuclear Physics Laboratory will be located within a "Q-cleared" area, with appropriate gaurd posts, patrolled fences, etc. All persons legally entering the building must have been previously granted a special permit. During non-working hours, the test cell entrances and exits and the vaults for fissionable material (and portable sources) will be security alarmed, doors to control rooms will be alarmed or sealed, and a security guard will patrol the remainder of the building. Entrances to cells and vaults will have three-way combination locks. Consoles will be key-locked. Even if the saboteur had normal access to the area, he is faced with extreme difficulties. A considerable amount of uninterrupted time and highly skilled work would be involved in accomplishing a sufficient number of the above listed modifications to cause a serious disaster. It is not likely that this could be done unobtrusively, nor without aid of additional personnel. It is firmily considered that pre-operational checks will uncover most acts of sabotage.

\section{Equipment Malfunction}

A strong effort will be made to design equipment to fail-safe. Monitoring circuits are sufficiently numerous to provide continied protection, even if several fail. In event of power fallure, a battery-operated monitor will continue to gather data. Power failure will also result in de-energizing motors, magnetic clutches and holding devices so that control and safety rods will be fired by spring pressure, and normal table drive stopped. Emergency power will be avallable to drive the table apart. Table limit-switches, and other important equipment in the cell will be mechanically protected against damage. Switches, relays, etc., will, where possible, be wired to fail-safe. In case of exceptions, multiple switching will be used in which chance of simultaneous failure is 
remote. Use of dependable equipment, combined with pre-operational check-out, operational monitoring, and frequent post-operational malntenance, will make multiple system failure extremely improbable.

3. Flood, Fire, and Earthquake

Possibility of accidents being caused by natural flooding is eleminated by locating the building in land where water cannot stand. Other flooding is prevented by elimination of water lines and drains in the test cells and vaults.

Damage by fire will be minimized by the initial fireproof design of the cells and strict regulation of flammable materials throughout the building. The uranium sheet used in the assembly will burn in the presence of air if sufficiently hot, but it seems very inlikely that this reaction could lead to a nuclear hazard.

Earthquakes have occurred in the area, but the chance of reoccurrence is considered slight. The cell structure should be quite adequate, and no distortions in the assemblies serious enough to make safeties inoperative are anticipated. Even if such distortions could occur in the assembly, the accompanying loosening of reactor parts probably will decrease the reactivity. 


\section{ENERGY AND RADIOACTIVITY RELEASE IN CASE OF ACCIDENT}

\section{General}

It has been shown that a compounding of several failures would be necessary to produce a serious reactor power excursion. Based on the remote possiblility that such combined failures could occur, a number of accidents have been analyzed to determine the amount of radioactive fission products that could be released to the surrounding area. The conditions assumed to produce these accidents involve partial or complete failure of safety systems and procedures, and exaggerated conditions of excess reactivity and operator negligence of sufficient degree to include results of sabotage.

Assuming that the safety systems completely fail to operate and that excess reactivity is introduced into the reactor, the only mechanism capable of overcoming the excess reactivit is a change in geometry of the assembly. The negative temperature coefficients are too small to compensate for more than a very small amount of reactivity. Therefore, an uncontrolled power excursion can be terminated only by a disassembly of the reactor by the pressure of vaporized fuel building up in the core.

If the reactor contains $80 \mathrm{~kg}$ of uranium, $54 \mathrm{Mw}-\mathrm{sec}$ of fission energy must be produced in the core to raise the temperature of the uranium to its boiling point; at least this much energy will be generated in any excursion. In addition, depending on the amount of excess reactivity introduced, further fission energy will be produced while the core is expanding, sufficient to shutdown the reactor. The power excursion and disassembly process has been analyzed for a series of cases, each of which assume a different amount of excess reactivity is introduced instantaneously at the start of the excursion. The details of the analysis are presented in Appendix A. Fig 15 gives the results of these calculations by presenting a graph of the total fission energy generated in the excursion vs the amount of instantaneous excess prompt reactivity introduced. In addition to these calculations, several problems have been analyzed in which reactivity is gradually introduced in a linear fashion corresponding to a case in which the tables are moved together or safety rods inserted producing a continuous insertion of reactivity.

Although in some cases the total fission energy produced is not sufficient to vaporize all of the uranium, the uranium will be at its melting point or above. After the reactor is destroyed, the uranium will probably oxidize in air releasing sufficient energy to vaporize all the uranium. Thus, it is assumed that all of the fission products are released into the test cell as a vapor.

2. Maximum Reactivity Additions

In considering the hazards associated with this experiment, several extreme accidents and the resulting reactivities have been investigated. The doses due to these accidents are reported in a later section.

The most extreme accident considered is the highly improbable, if not impossible, case of adding 13 percent excess reactivity instantaneously. It is postulated that in the process of determining the shutdown of the reactor and the worth of the control cylinders, the critical mass is measured with simulated control cylinders turned fully in (maximum poison effect). Then the loading and the control cylinder positions are modified to give initial conditions for the proposed power reactor. These modifications could continue with the addition of polsons to simulate fission products, until the end-of-life condition with peak xenon is mocked-up. If then additional information were required at the first test condition, i.e.. simulated control cylinders turned fully in, it is possible that the crew could remove 
P.WAC - 170

FIG 15

FISSION ENERGY RELEASE FOLLOWING INSTANTANEOUS REACTIVITY ADDITIONS

\section{LEGEND}

- ENERGY OF TRANSIENT AFTER VAPORIZATION OF FUEL BEGINS

-- TOTAL ENERGY OF TRANSIENT

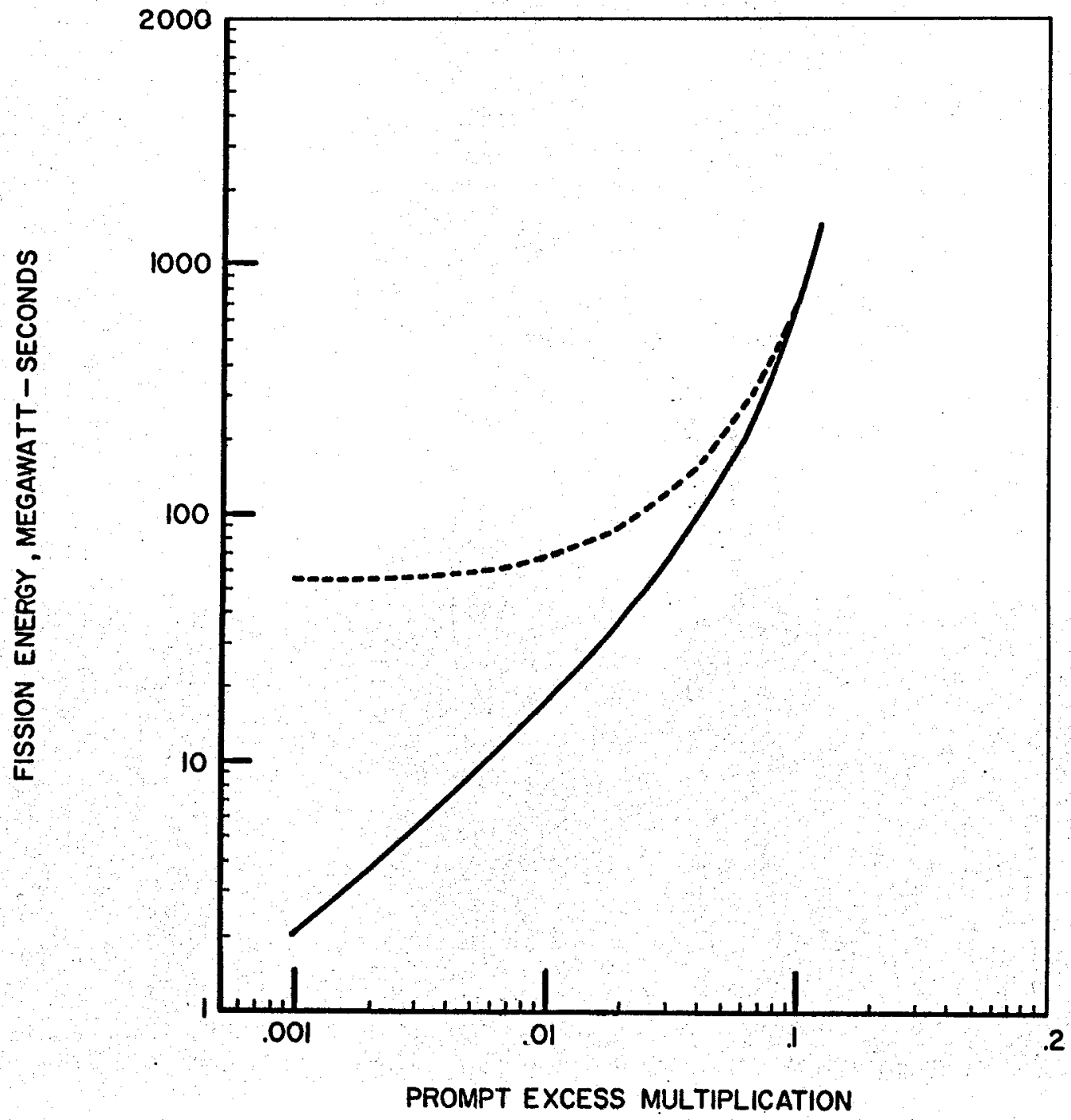


the poison and add the fuel to arrive at the initial loading, without rotating the control cylinders. Such a sequence of mistakes would leave the reactor with a potential 13 percent excess reactivity.

Even with 13 percent excess reactivity, the normal operating procedures would warn of the condition and if the normal procedures were disregarded, the safety mechanisms would prevent the reactor from being assembled. However, if all the safety mechanisms were inoperative, an accident would disperse the core before all the 13 percent reactivity could be introduced. For all 13 percent to be added, the core must be assembled at about $250 \mathrm{fps}$, which appears impossible. This is taken as the maximum hypothetical accident, i.e., 13 percent excess reactivity added instantaneously. The total fission energy release is $1500 \mathrm{Mw}-\mathrm{sec}$. Assuming the uranium vapor mixes uniformly with the air in the test cell, this energy release together with the energy of oxidation of the uranium would produce an excess pressure of 4 atmospheres in the test cell. Since this pressure is probably sufficient to rupture the test cell, it is assumed that all the fission products escape from the cell and are dispersed to the surrounding area.

Although it is difficult to imagine a mechanism to accomplish it, a slightly more realistic accident would be to insert the 13 percent excess reactivity during some short time interval rather than instantaneously. Therefore an accident involving the addition of reactivity at the rate of 13 percent per second has been analyzed. No normal failure of equipment could cause this rapid an insertion of reactivity, so that sabotage or catastrophy would have to be postulated to accomplish this. The total fission energy generated in this accident is $63 \mathrm{Mw}-\mathrm{sec}$. This energy combined with the energy of oxidation would produce an excess pressure of 1.1 atmospheres in the test cell which, as discussed below, may or may not be sufficient to rupture the cell and thus release all of the fission products.

Although the previous two examples give results for maximum conceivable accidents, it is more reasonable to consider the case of maximum rate of reactivity addition under conditions where it is possible to postulate a mechanism for the accident other than hypothetical sabotage or catastrophy. To arrive at the maximum rate at which reactivity could be added to the assembly, it is assumed that an accident occurs on the first approach to criticality after a change in core configuration has been made. Furthermore, this change has left the core with a greater reactivity than can be controlled by the safety rods. If the operator begins to close the tables and does not follow the power build-up as the core halves are assembled, a scram will occur. However, this negative reactivity has been assumed insufficient to shutdown the core. It is now assumed that the motor controller, which prevents the 3-phase motors from operating if one phase of the line fails, becomes inoperative at the moment of the scram. Then the safety motor, which is idling in the direction of assembling the reactor, will continue to run on singlephase power and the reactor halves will close at 40 inches per minute, introducing an estimated 3.2 dollars per second rate of reactivity change. The total fission energy released in this type of excursion is $58 \mathrm{Mw}-\mathrm{sec}$ which, combined with the energy of oxidation, would produce an excess pressure of 1.06 atmospheres in the test cell. Since the test cell can probably withstand this pressure rise, the fission product release to the atmosphere can be calculated by assuming the fission products mix uniformly with the air in the test cell and then enough air flows out of the cell to relieve the excess pressure. In this case 40 percent of the fission products would be released. However, in computing the dose to the surrounding area, the more pessimistic assumption is made that all of the fission products escape. 


\section{HAZARDS TO SURROUNDING AREA}

\section{General}

This section discusses the possible radiation hazards to both on-site and off-site personnel. The nearest on-site personnel are located approximately 1000 feet srom the Nuclear Physics Laboratory; the nearest civilian residences are a little more than onehalf mile away. The center of the nearest village is about 4000 feet away. Doses were calculated also for a distance of 10,000 feet to illustrate their level at a considerable distance from the laboratory.

The doses were calculated using methods described in detail in Appendix B. These methods give a very pessimistic picture of doses resulting from activity released.

It was assumed that from a point source a single cloud was released containing $1.8 \mathrm{x}$ 1018 fission product nuclei, all of the fission products from a power excursion of 58 Mw-sec $\left(5.5 \times 10^{4}\right.$ Btu) fission energy. A table is provided containing factors to convert the doses from power excursions of other energies and a table is included which lists reference values for permissible amounts of radioisotopes in the body.

\section{External Doses From Radioactive Cloud}

Integrated external beta and gamma doses received by a person standing on the centerline of the cloud path as the cloud moves along the ground from its point of origin to infinity are given in the following table.

\section{External Doses from the Cloud}

Beta Doses, rep (LD50 100,000 rep)

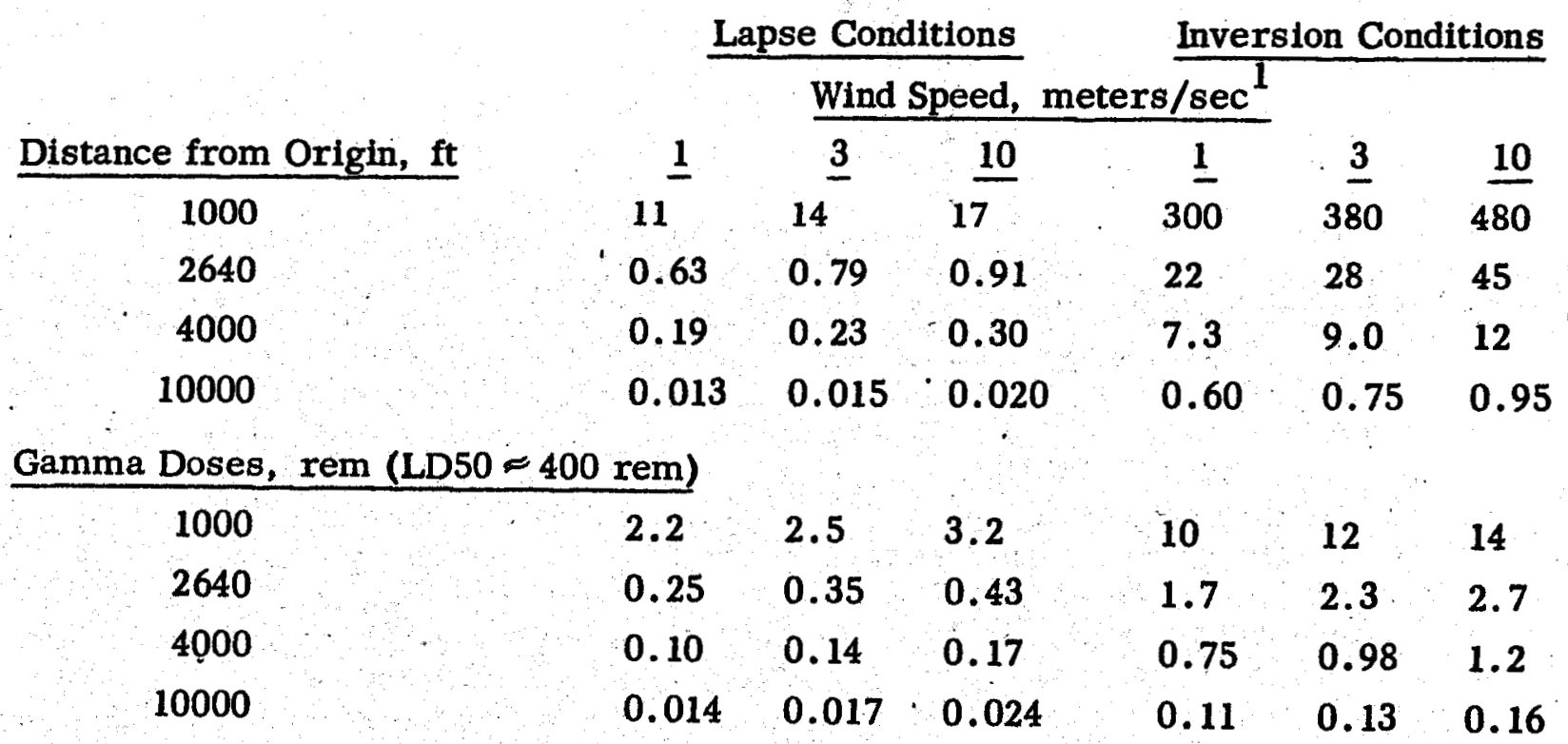

3. Inhalation Doses

Lifetime doses to various organs from inhalation by a person standing on the centerline of the cloud path as the cloud moves along the ground from its point of origin to infinity are given in the following table.

Note: ${ }^{1}$ One meter/sec is equal to $2.24 \mathrm{mph}$. 


\section{Inhalation Doses to Organs}

Distance from Origin, ft

Lapse Conditions

Inversion Conditions

Wind Speed, meters/sec

\begin{tabular}{rlllllll} 
Lung Doses, rep & 1 & 3 & 10 & 1 & 3 & 10 \\
\hline 1000 & 3.7 & 1.6 & 0.59 & 100 & 45 & 17 \\
2640 & 0.55 & 0.24 & 0.091 & 19 & 10 & 3.1 \\
4000 & 0.25 & 0.11 & 0.040 & 9.5 & 4.1 & 1.5 \\
10000 & 0.041 & 0.018 & 0.0065 & 2.0 & 0.88 & 0.32
\end{tabular}

Thyroid Doses, rep

$\begin{array}{rllllll}1000 & 3.0 & 0.99 & 0.30 & 84 & 28 & 8.4 \\ 2640 & 0.55 & 0.18 & 0.054 & 19 & 6.6 & 2.0 \\ 4000 & 0.26 & 0.086 & 0.026 & 10 & 3.4 & 1.0 \\ 10000 & 0.051 & 0.017 & 0.0053 & 2.5 & 0.84 & 0.26\end{array}$

Bone Doses, rep

$\begin{array}{lllllll}1000 & 3.4 \times 10^{-2} & 1.1 \times 10^{-2} & 3.3 \times 10^{-3} & 8.7 \times 10^{-1} & 2.9 \times 10^{-1} & 8.8 \times 10 \\ 2640 & 6.2 \times 10^{-3} & 2.0 \times 10^{-3} & 6.0 \times 10^{-4} & 2.1 \times 10^{-1} & 6.7 \times 10^{-2} & 2.1 \times 10 \\ 4000 & 3.0 \times 10^{-3} & 9.3 \times 10^{-4} & 2.9 \times 10^{-4} & 1.1 \times 10^{-1} & 3.6 \times 10^{-2} & 1.1 \times 10 \\ 10000 & 5.7 \times 10^{-4} & 1.9 \times 10^{-4} & 5.7 \times 10^{-5} & 2.8 \times 10^{-2} & 9.2 \times 10^{-3} & 2.8 \times 10\end{array}$

The amounts initially retained in the body of the radioisotopes contributing to the doses to the organs are given in Fig 16 . Amounts retained in the lungs are not given since the doses to the lungs were calculated as being from a mixture of all short-lived fission products. The following table lists values from NBS Handbook $\mathbf{5 2}$ for the maximum permissible amounts of various radioisotopes in the body for continuous exposure.

Maximum Permissible Amount of Radioisotope in Total Body for Continuous Exposure

"MPA" (microcuries) From Table 3, NBS Handbook 52

\begin{tabular}{ll} 
Radioisotope & $\frac{\text { MPA }}{0.30}$ \\
\hline $\mathrm{I}^{131}$ & not given \\
$\mathrm{I}^{133}$ & not given \\
$\mathrm{I}^{135}$ & 2.0 \\
$\mathrm{Sr}^{89}$ & 1.0 \\
$\mathrm{Sr}^{90}+\mathrm{Y}^{90}$ & 15 \\
$\mathrm{Y}^{91}$ & 5.0 \\
$\mathrm{Ba}^{140}+\mathrm{La}^{140}$ & 5.0 \\
$\mathrm{Ce}^{144}+\mathrm{Pr}^{144}$ &
\end{tabular}




\section{QUANTITIES RETAINED IN ORGANS}

Quantities retained in the Thyroid, microcuries

\section{Wind Speed $=6$ meters $/ \mathrm{sec}$}

Lapse Conditions

\begin{tabular}{|c|c|c|c|}
\hline Distance from Origin, $\mathrm{ft}$ & $1^{131}$ & $I^{133}$ & $I^{135}$ \\
\hline 1000 & $8.6 \times 10^{-3}$ & $1.8 \times 10^{-1}$ & $5.1 \times 10^{-1}$ \\
\hline 2640 & $1.6 \times 10^{-3}$ & $3.3 \times 10^{-2}$ & $9.2 \times 10^{-2}$ \\
\hline 4000 & $7.5 \times 10^{-4}$ & $1.6 \times 10^{-2}$ & $4.4 \times 10^{-2}$ \\
\hline 10000 & $1.5 \times 10^{-4}$ & $3.2 \times 10^{-3}$ & $9.0 \times 10^{-3}$ \\
\hline
\end{tabular}

\section{Inversion Conditions}

$\begin{array}{lll}\frac{1^{131}}{133} & \frac{1^{135}}{134} & \frac{13.0}{14} \\ 0.056 & 1.2 & 3.5 \\ 0.031 & 0.64 & 1.9 \\ 0.0075 & 0.16 & 0.44\end{array}$

Quantities retained in the Bone, microcuries

\section{Lapse Conditions}

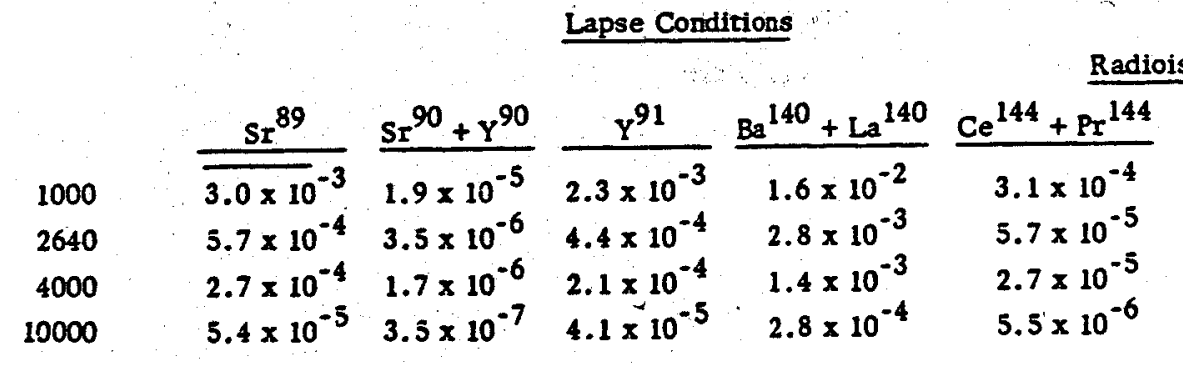

\section{Radioisotopes}

$\begin{array}{cccccc}\mathrm{Sr}^{89} & \frac{\mathrm{Sr}^{90}+\mathrm{Y}^{90}}{8.4 \times 10^{-2}} & 5.3 \times 10^{-4} & 6.4 \times 10^{-2} & \frac{\mathrm{Ba}^{91}+\mathrm{La}^{140}}{4.3 \times 10^{-1}} & \frac{\mathrm{Ce}^{144}+\mathrm{Pr}^{144}}{8.5 \times 10^{-3}} \\ 2.0 \times 10^{-2} & 1.3 \times 10^{-4} & 1.5 \times 10^{-2} & 1.0 \times 10^{-1} & 2.0 \times 10^{-3} \\ 1.1 \times 10^{-2} & 7.0 \times 10^{-5} & 8.1 \times 10^{-3} & 5.5 \times 10^{-2} & 1.0 \times 10^{-3} \\ 2.6 \times 10^{-3} & 1.7 \times 10^{-5} & 2.0 \times 10^{-3} & 1.4 \times 10^{-2} & 2.7 \times 10^{-4}\end{array}$.

Inversion Conditions 


\section{External Doses from Fallout and Rainout}

Lifetime external beta and gamma doses from fallout received by a person standing on on the centerline of the cloud path are given in the following table. For each point, the doses have been maximized by assuming that the cloud strikes the ground at that point. The initial cloud height is taken to be $70 \mathrm{feet}$, a value that should be representative of emission height.

The lifetime external gamma doses received by a person standing on the centerline of the cloud path from the material deposited on the ground by a light rain falling through the cloud are also given in the following table. For each point, the doses have been maximized with respect to distance. The beta doses are assumed to be negligible because of shielding by water and earth.

\section{External Doses from Fallout and Rainout}

Fallout Beta Doses, rep (LD50 100, 000)

Lapse Conditions

Inversion Conditions

Wind Speed, meters/sec

\begin{tabular}{rrrrrrrr} 
Distance from Origin, ft & $\underline{1}$ & $\underline{3}$ & $\underline{10}$ & $\underline{1}$ & $\underline{3}$ & $\underline{10}$ \\
\hline 1000 & 1200 & 1400 & 1900 & 33,000 & 40,000 & 53,000 \\
2640 & 67 & 81 & 100 & 2,400 & 3,000 & 3,900 \\
4000 & 22 & 24 & 30 & 790 & 980 & 1,300 \\
10000 & 1.3 & 1.5 & 2.1 & 65 & 80 & 100
\end{tabular}

Fallout Gamma Doses, rem (LD50 $\approx 400$ rem)

$\begin{array}{rlllllll}1000 & 11 & 14 & 18 & 170 & 220 & 280 \\ 2640 & 0.77 & 0.96 & 1.2 & 16 & 22 & 26 \\ 4000 & 0.24 & 0.30 & 0.39 & 5.8 & 7.7 & 9.2 \\ 10000 & 0.020 & 0.024 & 0.030 & 0.60 & 0.78 & 0.95\end{array}$

$\underline{\text { Rainout Gamma Doses, rem (LD50 } \approx 400 \mathrm{rem} \text { ) }}$

$\begin{array}{llll}1000 & 9.4 & 12 & 15 \\ 2640 & 1.5 & 1.8 & 2.4 \\ 4000 & 0.66 & 0.83 & 1.1 \\ 10000 & 0.12 & 0.15 & 0.19\end{array}$

5. Dose Conversions for Other Accidents

The following table contains conversion factors that may be used with the tables above to calculate doses for excursions of other total fission energies. The excursions for which conversion factors are given are those which have been considered elsewhere in this report. As an example of the use of this table, the worst dose at 2640 feet from an. 
accident of $1500 \mathrm{Mw}$-sec energy would be the fallout gamma dose of $26 \times 26 \mathrm{rem}$, or $680 \mathrm{rem}$.

Factors for Use with Dose Tables

\begin{tabular}{llll} 
Accident & \multicolumn{1}{c}{$\frac{\mathrm{dk}}{\mathrm{dt}}$} & $\begin{array}{l}\text { Excursion } \\
\text { Energy (Mw-sec) }\end{array}$ & Factor \\
motor bringing halves together & $\$ 3.20 / \mathrm{sec}$ & 58 & $1.0^{*}$ \\
(Mechanism Unknown) & $13 \% / \mathrm{sec}$ & 63 & 1.1 \\
(Mechanism Unknown) & $13 \%$ instantaneously & 1500 & 26
\end{tabular}

* The dose tables are calculated for an accident of energy $58 \mathrm{Mw}-\mathrm{sec}$.

6. Beryllium Inhalation

As stated in the discussion on accident analysis, it is doubtful that there would be sufficient heat-transfer between the fuel and any other part of the reactor assembly to cause the vaporization of any other material. However, if there were, a hazard to personnel would result from the beryllium. Medical reports indicate that a few moments' inhalation of air containing beryllium oxide in a concentration of the order of 100 micrograms per cubic meter is sufficient to cause acute berylliosis in most people. If the amount of beryllium (as beryllium oxide) in the accident cloud were of the order of 1 gram, the concentration near the center of the cloud could be large enough to cause acute berylliosis. However, the concentration decreases very rapidly with distance from the center of the cloud, and at 2640 feet the concentration 35 feet from the center of the cloud is sufficiently low that no danger of acute berylliosis would arise. Considerably larger amounts of beryllium oxide would have to be released in order to give rise to any other forms of beryllium poisoning.

\section{Discussion}

It has been shown that the maximum doses are the fallout doses under inversion conditions, for which it is reasonable to assume a low prevalling-wind speed, e.g., 3 meters per sec. At one-half-mile distance, which is closer than the nearest dwelling, the beta dose is 4 percent of LD50 and the gamma dose is 6 percent. Since it is known that biological reaction to radiation exposure decreases very rapidly with decrease in dose, these estimates do not appear particularly threatening to off-site personnel.

To be conservative, very pessimistic assumptions were made in deriving the equations for calculating doses resulting from activity released. There are several ameliorating factors for which allowance should be made. First, some of the active material may adhere to surfaces in the test cell and never be released. Secondly, additional decay would occur if the expulsion of material were not instantaneous. The non-zero actual initial volume of the cloud will also reduce the cloud concentrations.

The discussion in the preceding paragraph applies to all the dose calculations. Generally, there are additional ameliorating factors peculiar to each type of dose calculation. Since the fallout beta and gamma doses are the worst off-site hazards, some of these other factors pertaining to their calculation should be mentioned. First, it is likely that the fission product particles would occur in the cloud with a distribution in size rather than all of the same size as is required for the assumed fallout mechanism. This would tend to reduce the amount of material contributing to a dose at a specific point. Secondly, the effects of evacuation or decontamination on reducing the doses is considerable in the 
first few hours after fallout, as is illustrated in Fig 21 in Appendix B. It is likely that the above factors would combine to reduce even the maximum (fallout) doses from the $1500 \mathrm{Mw}-\mathrm{sec}$ excursion to well below LD50.

The probability of off-site personnel receiving any dose at all is itself a product of several probabilities; notably: that the accident would occur, that radioactive material escapes, that the weather conditions are such as to direct the material toward the personnel, and, for fallout, that the radioactive material is in such a form as to be capable of falling out in the vicinity of personnel. 


\section{CHARACTERISTICS OF SURROUNDING AREA}

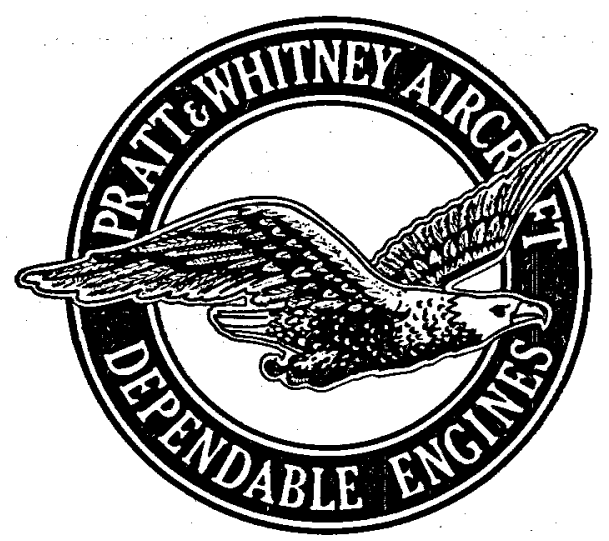

SECOND HAZARDS SUMMARY REPORT

FOR CANEL NUCLEAR PHYSICS LABORATORY

MAY 24, 1957 


\section{A. POPULATION DISTRIBUTION}

The Connecticut Aircraft Nuclear Engine Laboratory (CANEL) including the Nuclear Physics Laboratory is located on a tract of land on the west bank of the Connecticut River, approximately 18 miles south of Hartford and 5 miles southeast of Middletown. The largest community in the vicinity is Middletown with a population of 20,000 persons. The location of the site relative to adjacent communities is shown in Fig 17. The CANEL site covers 1200 acres and is roughly circular with a radius of $4000 \mathrm{ft}$. It is bounded to the north and east by the Connecticut River. The critical facility is approximately one-half mile inside this circle and 3000 feet from the nearest residence. A distance of 1000 feet separates the Nuclear Physics Laboratory from other facilities buildings on the site. The location of the Nuclear Physics Laboratory relative to the site boundaries and other facility buildings is shown in Fig 18.

The population distribution at various radil from the center of the site is given in Fig 19. This distribution is based on the 1950 census. The major concentration of people is to the north and west of the site. There are 830 people outside the site boundaries but within a twomile radius. There are 23,290 people within a five-mile radius, 66,010 within a ten-mile radius, and 207,547 people within a twenty-mile radius. 


\section{TOPOGRAPHICAL MAP OF CANEL SITE AREA}

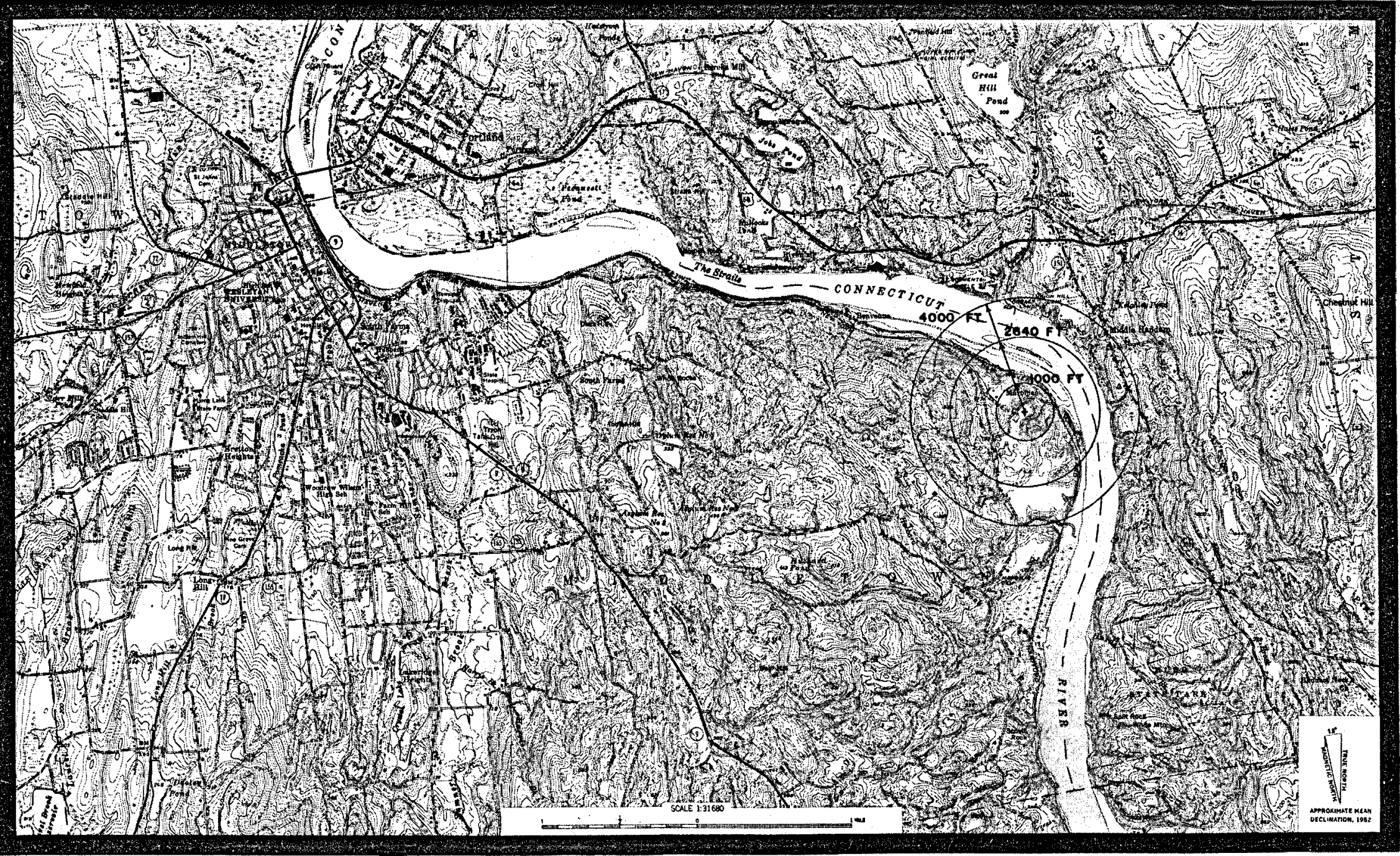




\section{CANEL FACILITY SITE PLAN}

SITE BOUNDARY

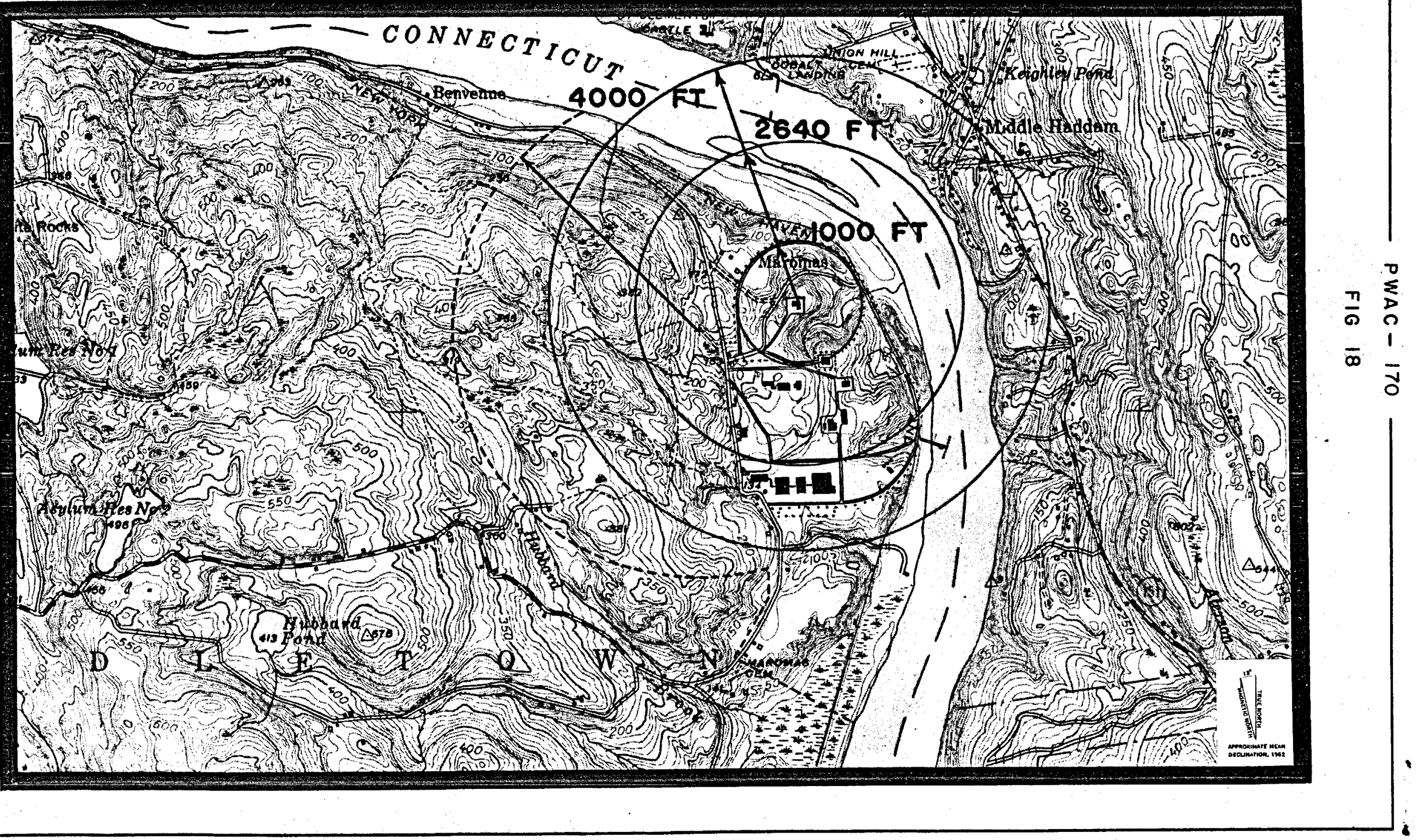




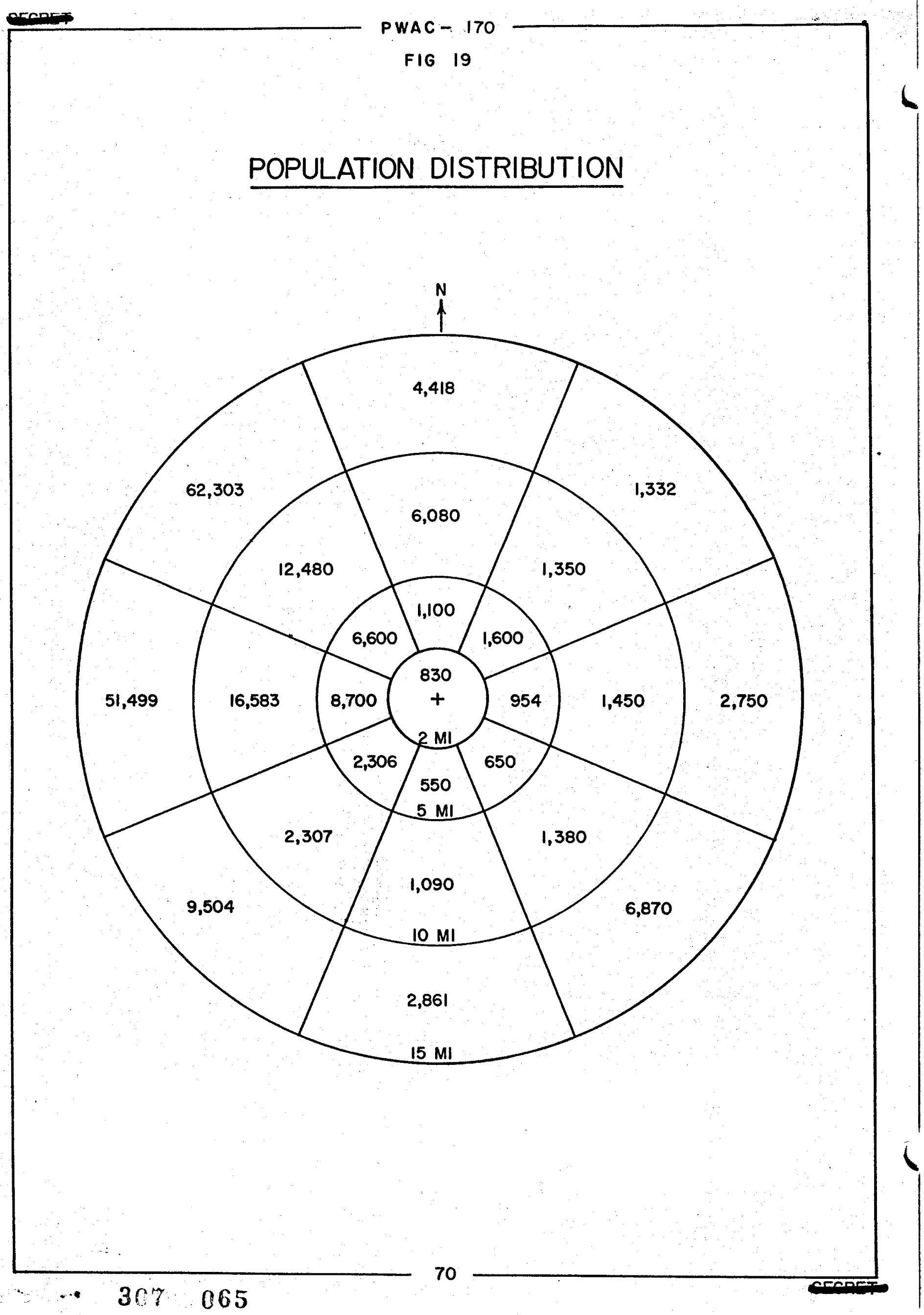




\section{B. VITAL INSTALLATIONS NEAR SITE}

The nearest vital installation to the site is the $68,500 \mathrm{kw}$ steam-electric generating station of the Hartford Electric Light Company. This represents approximately 20 percent of the total capacity of the Connecticut Power Company. The Hartford Electric generating station is on the Connecticut River 5000 feet northwest of the Nuclear Physics Laboratory.

There are a number of municipal water reservoirs within 10 miles of the site. The nearest are the 5 reservoirs of the State Asylum. These are located approximately 1-3/4 miles west of the Nuclear Physics Laboratory. The City of Middletown draws its drinking water from two reservoirs 6-1/2 and 7-1/2 miles west of the site center. The city of Portland has a single reservoir 5 miles north of the center of the site.

The other vital installation within 10 miles of the site is the Guided Missile Station at Portland, 6 miles north of the site.

There are a total of 10,000 industrial workers employed by 19 different industries within a ten-mile radius of the site. Figs 22 and 23 in Appendix $\mathrm{C}$ show the detailed distribution of the workers with respect to geography and type of industry within this area. Fig 24 lists the number of workers employed by each establishment. Roughly 75 percent of the total number of workers listed above are employed in the Middletown-Portland area. The distribution of workers among the different industries is fairly uniform; ten industries each employ approximately $\mathbf{5 0 0}$ or more workers. The largest establishments in the area are Russell Mfg. (textiles) with 1050 workers, Robert Gair Co. (paper), Goodyear Rubber, and Emhart-St'd Knapp Div. (machinery) each with 750 workers, and Wilcox-Crittenden \& Co. (fabricated metal) and Eis Automotive Corp. (transportation equip.) each with 375 workers. These establishments are all located in the Middletown-Portland region and together employ 40 percent of the total number of industrial workers. The remainder are employed by establishments with 150 workers or less. 


\section{RAILROAD, RIVER AND AUTOMOBILE TRAFFIC}

A single track of the New York, New Haven, and Hartford Railroad skirts the site on the north and east on the Connecticut River bank. This line is used for carrying freight only. One train per day is scheduled to travel down to Essex, Connecticut, and back on this track. The railroad track is approximately 1000 feet from the Nuclear Physics Laboratory.

Approximately 1300 boats of all types pass the site per year in each direction on the Connecticut River. The boats pass at a distance approximately 2000 feet from the Nuclear Physics Laboratory.

The nearest automobile highway is Route 151 which is 3500 feet east of the Nuclear Physics Laboratory on the east bank of the Connecticut River. Heavily traveled highways in the vicinity of the site are Route $6 \mathrm{~A}$, which passes about 5000 feet north of the laboratory, and Route 9, passing about 15,000 feet to the west. 


\section{METEOROLOGY}

\section{General}

Although the meteorological information collected to date at CANEL is still limited, quite complete data have been taken for many years at Hartford, Connecticut. Considering the influence of the river valley and general rough terrain on some of the meteorological parameters at the site, the major climatic features can be satisfactorily defined by the Hartford records, which are summarized below.

The wind directions at the Hartford Station are almost equally divided into winds from the northerly quadrant and from the southerly quadrant. Almost half the winter winds are from a northerly direction; in summer 45 percent of the wind directions are southerly. In spring and fall there is an almost equal frequency of both northerly and southerly winds. On the average, winds from the easterly quadrant occur less than 10 percent of the time.

Except for the summer months, the prevailing rain wind is north and north-northeast. During summer the most frequent rain wind is south.

Over 50 percent of the wind speeds will be in the 4 to 12 mph category, with a high percentage of wind less than $4 \mathrm{mph}$. Spring is the season of the strongest average winds with a mean speed of $9.4 \mathrm{mph}$ compared to the summer low of $7.0 \mathrm{mph}$. The highest recorded one-minute wind speed at Hartford is $70 \mathrm{mph}$.

Tornadoes are rare in Connecticut, with only nine reported during the period 1916 through 1950. Thunderstorms are common in July, with an average of seven per month. Thunderstorm winds are extremely variable, but a rare severe storm may cause shortduration winds in excess of $50 \mathrm{mph}$.

The Hartford area receives approximately 40 inches of precipitation annually spread over an average of 127 days, with a fairly uniform distribution. The snowfall averages about 40 inches per year with one inch or more of snow occurring approximately 10 days per year.

There are roughly 45 days per year during which a heavy fog occurs. Visibility is reduced to 6 miles or below approximately 30 percent of the time. Although inversions form nearly every night, there is nothing in the records that could be interpreted to signify that Hartford experiences an unusual amount of stable atmospheric conditions.

The narrower valley at CANEL and the protective surrounding terrain should result in lower average wind speeds than those reported at Hartford. The channeling effect noted at Hartford should be even more pronounced, with a large predominance of north or northwest and southerly winds. However, at night during periods of light winds the terrain will probábly cause westerly drainage winds downslope from the surrounding hills and into the river valley. These air movements will be more in the nature of a drift and should rarely exceed 2 to 3 miles per hour.

It is possible that the sea breeze from Long Island Sound may reach the site. However, it seems evident that such occasions will be infrequent, and on those occasions the site would be affected for only short intervals of time.

Another effect of the surrounding terrain will be to shield the site plateau from early morning and, particularly, late afternoon solar radiation. This will probably result in 
earlier formation and slightly later dissipation of the nocturnal inversion that would be experienced on a level plain in the same location.

A third difference will result from the proximity of the Connecticut River. In summer and early fall the cooler water of the river will favor early inversion formation and frequent fogs which may well deepen to encompass the site plateau. In the winter and spring the relatively warm water will lift the inversion base from the ground to 50 or 100 feet above the water and will favor earlier breakup of nocturnal inversions.

\section{Existing-Site Meteorological Data}

While the twelve months of extensive data plus the additional three months of limited data now available from the CANEL site cannot be considered conclusive, the information does suggest trends of significant note. Three aspects of the collected data, wind, temperature gradient, and dispersion parameters, are worthy of treatment here.

\section{a. Wind}

For the twelve months analyzed, March, 1956 (partial) through March, 1957, the channel effect is much more pronounced at the site as compared to Hartford. Also the channel axis of predominant wind flow is along a line from the northwest northnorthwest sector to the south southeast sector.

Important also is the large percent of calms, as measured at the fifteen-foot level above ground. Over the entire period the wind was calm 24.1 percent of the time.

Several Beckman \& Whitley low-threshold $(0.75 \mathrm{mph})$ wind measuring units have been placed at various locations on the site, and the collected data analyzed for the summer (June, July, and August) reveal some noteworthy facts. There is definite evidence of some drainage from the slopes west of the site plateau, during stable (nighttime) conditions. The drainage is very low velocity, with a recorded maximum of $3 \mathrm{mph}$. The maximum drainage speed occurs at the mouths of large ravines. The depth of the drainage has not been determined, but it seems certain that it is less than 200 feet, and probably less than 50 feet. During unstable conditions (daytime lapse) there is some upslope motion along the hills, more so with southerly winds than with northerly winds, which tend to parallel the contours of the slopes.

During times of precipitation a higher percentage of wind from the north-northeast and northeast and a lower percentage from the west as compared to the overall average was noted.

Wind roses illustrating the above remarks are found in Appendix D.

\section{b. Temperature Gradient}

Considering the vertical temperature gradient from 5 feet to 200 feet for the period from late March, 1956, through February, 1957, several factors are significant. Inversions occurred 36.5 percent of this time. Over 75 percent of this inversion time occurred during the nighttime (7pm through $6 \mathrm{am}$ ) and inversions existed well over half of the total nighttime. Inversions occur during the daytime (7am through $6 \mathrm{pm}$ ) less than 25 percent of the time. The most frequent duration of an inversion was 11 to 15 hours, and during the noted period there were 31 cases where the inversion persisted 16 to 20 hours, one case of 21 to 25 hours, one case of 31 to 40 hours, and one case of 41 to 50 hours persistence. 
Thus on the basis of the nearly one-year period of time considered, it is noted that over a third of the time the site will be under an inversion condition, that over three-fourths of this inversion time will occur at night, that inversions will occur at least half of the total nighttime, and that once a nocturnal inversion sets in it can be expected to persist throughout the night.

\section{c. Dispersion Parameters}

The stability index " $n$ " has been calculated for a large number of cases (4118) over the three seasons, summer, fall, and winter (June through February).

Similarly, the diffusion coefficient " $\mathrm{C} 2$ " has been calculated for a large number of cases (4548) over the same period. The assumption of isotropic conditions, that is, $\mathrm{C}^{2}=\mathrm{Cy}^{2}=\mathrm{Cz}^{2}$, is made. The results of these calculations are tabulated below.

\begin{tabular}{|c|c|c|c|}
\hline Condition & $\begin{array}{l}\text { Lapse Rate } \\
5 \text { to } 200 \text { feet }\end{array}$ & Average "n" & $\begin{array}{l}\text { Average "C2" at } 200 \text { feet } \\
\text { with } 7 \mathrm{mph} \text { wind }\end{array}$ \\
\hline Very Unstable (strong lapse) & -2.1 or less & 0.27 & 0.23 \\
\hline Unstable (mild lapse) & -2.0 to -1.1 & 0.27 & 0.17 \\
\hline Neutral & -1.0 to -0.1 & 0.34 & 0.11 \\
\hline Stable (mild inversion) & 0.0 to 3.0 & 0.47 & 0.07 \\
\hline Very Stable (strong inversion) & 3.1 or greater & 0.55 & 0.06 \\
\hline
\end{tabular}

\section{CANEL Meteorological Station}

The collection of meteorological data at the CANEL site began during late December, 1955, when a portable wind speed and direction recording unit was put into operation. By midMarch, 1956, a 200-foot meteorological instrument tower and a laboratory for housing recording equipment had been erected on the site. By April the tower and laboratory were operating on a routine basis. The two U.S. Weather Bureau Meteorologists assigned to this project are operating this CANEL weather station.

Instrumentation on the tower includes units for measuring wind speed and direction at the 15-foot level and the 200-foot level, a dew-point measuring device and a thermocouple for measuring ambient temperature at the five-foot level, and a series of thermocouples for measuring temperature gradients between 5 and $50 \mathrm{feet}, 5$ and $150 \mathrm{feet}$, and 5 and 200 feet. All of this information is recorded continuously in the laboratory. In addition, a continuous recording rain gage is located near the base of the tower, and visual observations of sky cover, visibility, and weather and obstruction to vision, are recorded during weekday daylight hours.

This information, recorded on an hourly basis, is sent monthly to the United Aircraft Corporation Computation Laboratory where it is recorded on punch cards and fed into the IBM-704 for summation and magnetic tape storage. The resultant summary is returned to CANEL for analysis and record. The summary consists of a number of frequency and correlations tables, such as frequency of occurrence of temperature gradients (a summation of inversions and lapse conditions), frequency of persistence of inversions and lapse conditions, correlation of wind direction with temperature gradients, and various wind speed and direction correlations and frequency tables. A complete list of tabulated summaries can be found in Appendix $D$.

Supplementing the routine collection of continuous wind, temperature, precipitation, 
and humidity data from the 200-foot tower, a program of special micrometeorological analys is is underway. Portable wind recorders are being placed at various locations on the site in an attempt to analyze the significance of cold air drainage, flow along ravines, effect of trees and other obstruction, and various other parameters. Doubletheodolite neutral balloon runs, temperature-recording captive balloon runs, and photographic smoke studies are also included in this program. Many of these tests have already been undertaken and their results are being analyzed. Preliminary estimates of diffusion coefficients are possible as a result of these tests, and have been noted in this report. 


\section{E. GEOLOGY AND HYDROLOGY}

The proposed structures at CANEL will be built on a deposit of glacial sand that forms a terrace about 140 feet high overlooking the Connecticut River. Glacial sand probably also underlies the river. Beneath the sand is a layer of dense glacial till; beneath the till is folded and recrystallized bedrock of Precambrian Age.

The terrace material is permeable and its upper surface is relatively flat. It is tentatively concluded that ground water in the terrace discharges into the Connecticut River only. Therefore, a liquid spill would tend to percolate downward and thence move with ground water into the river. Conversely, any large-capacity well would withdraw ground water from most parts of the terrace and from the river.

The Connecticut River is tidal at the reservation with a maximum tidal range of about $2-i / 2$ feet, which decreases with increasing river discharge. Average discharge is about 17,300 cubic feet per second. During periods of low discharge, usually in August and September of each year, the effect of tide is sufficient to cause reversal of current. Maximum upstream current is estimated at about 1 foot per second. Maximum travel distance of upstream current is as yet unmeasured. Usual location of saline-fresh water contact is 13 to 20 miles downstream; during very low discharge saline water moves to within 10 miles of the reservation, and in flood flows is completely flushed out of river.

No public water-supply in the State of Connecticut takes Connecticut River water. The river is used for commercial and pleasure boating, and fishing, and swimming. No private consumptive use of river water is known, but inventory is yet to be made. It is believed that no existing water well would be affected by plant operations, except, perhaps, the well of the Hartford Electric Light Company generating station at Benvenue, Connecticut. 


\section{F. SEISMOLOGY}

To assess the probability of occurrence of earthquakes, the earthquake history of the Middletown area was investigated. From these results, it is possible to conjecture as to the future possibility of an earthquake occurring in this region.

The State of Connecticut is reported to have had twelve earthquakes which had their epicenters within the state boundaries. Undoubtedly more shocks have occurred, but they were not recorded because of their small areal influence and low intensity. The recorded shocks had intensities that varied from 4 to 8 on the Rossi-Forel scale of intensities.

The date, location, area affected, and intensity of the reported shocks is given at the end of Appendix E. From the past records it would appear that there is little danger from earthquakes. However, inasmuch as they have occurred in the past, precautions will be taken to insure that all structures containing critical material will be constructed to withstand moderate shocks. 
V. APPENDICES

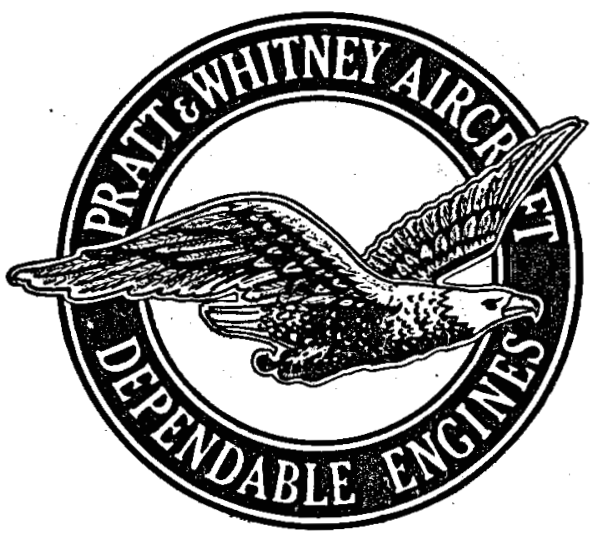

HAZARDS SUMMARY REPORT ON

CRITICAL EXPERIMENT PROGRAM NO. 1 AT CANEL

MAY 24, 1957

$307 \quad 074$ 


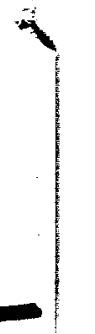




\section{A. ANALYSIS OF ACCIDENT}

The analysis presented here has been developed to describe the behavior of the reactor when excess reactivity has been introduced into the system, either gradually or instantaneously, which the safety system fails to counteract. It is postulated that the reactivity thus introduced is decreased only by core expansion caused by internal pressure resulting from vaporization of the fuel. The main purpose of the analysis is to estimate the fission energy release and the number of fission products produced by the time the disassembly process has terminated the excursion.

The analysis follows the history of various physical features of the system such as number of neutrons, power level, energy developed, temperature, pressure, core radius, amount of uranium vaporized, etc., from the time the reactor is operating normally at a one-watt level at room temperature (at which time excess reactivity is introduced either gradually or instantaneously) through the entire power excursion to disassembly. The model chosen is a spherical reactor with reflector. The power distribution is assumed to be flat across the core. It is assumed that the entire nuclear energy developed goes into heating and vaporizing the uranium without transferring heat to the other materials of the core because of the short times involved in the excursion. It is, therefore, the pressure of the vaporized uranium gas which causes expansion of the core and disassembles the reactor. The mathematical description of the excursion has been coded for the IBM-704 computer, and this makes it possible to follow. the assumed process with very small time intervals and in reasonably complete detail.

For instantaneous changes in reactivity the equations which were used to define the physical model are as follows. The number of neutrons in the system at any instant is determined from the solution of the pile kinetic equations which relate the number of neutrons ( $n$ ) in the reactor at any time $(t)$ with the number of delayed-neutron emitters (Ci) present.

$$
\begin{aligned}
& \frac{\mathrm{dn}}{\mathrm{dt}}=\frac{\mathrm{k}(1-\beta)-1}{\ell} \mathrm{n}+\sum_{i=0}^{5} \lambda_{i C i} \\
& \frac{\mathrm{dC}_{i}}{\mathrm{dt}}=\frac{\mathrm{k} \beta_{i n}}{\ell}-\bar{\lambda}_{\mathrm{iCi}}
\end{aligned}
$$

where $k$ is the reactivity, $l$ the generation time of the reactor, $\lambda i$ is the decay constant, and $B_{i}$ the fraction of fission neutrons emitted by the $i$ th emitter. These equations may be solved on the computer in a step-by-step manner for small time intervals $\Delta t$ by having:

$$
\begin{aligned}
& \mathrm{n}=\mathrm{n}_{\mathrm{o}} \mathrm{e}^{a \Delta \mathrm{t}} \\
& \mathrm{C}_{\mathrm{i}}=\mathrm{C}_{\mathrm{io}} \mathrm{e}^{\boldsymbol{\gamma}_{\Delta t}} \\
& \text { where } a=\frac{k(1-\beta)-1}{l}-\sum \frac{\lambda_{i C i}}{n} \\
& \text { and } \gamma_{i}=\frac{k n \beta_{i}}{\ell C_{i}}-\lambda_{i}
\end{aligned}
$$

and $\mathrm{n}_{\mathrm{o}}$ and $\mathrm{C}_{\mathrm{io}}$ are the values at the beginning of the time interval

Therefore, the power at the end of an interval is:

$$
P=P_{0} e^{a \Delta t}
$$


and the energy generated during the interval is:

$$
\Delta \mathrm{E}=\frac{\mathrm{P}_{\mathrm{O}}}{a}\left(\mathrm{e}^{a \Delta \mathrm{t}}-1\right)
$$

If the core contains $80 \mathrm{~kg}$ of fuel, the energy required to reach the boiling temperature of uranium is $54 \mathrm{Mw}-\mathrm{sec}$. Therefore, until this amount of energy has been supplied, the only process taking place is the heating and melting of the uranium metal at a rate determined by the excess $k$ added and the delayed neutrons.

After the boiling point of the uranium has been reached, the energy generated will go into vaporization of the uranium and into work done by the resulting gas pressure in pushing the core apart. To simplify calculations it has been assumed that there will be no further heating of uranium vapor until vaporization is complete. This assumption is allowable because the vaporization and the heating have been found to have about the same effect. After $54 \mathrm{Mw}-\mathrm{sec}$ of energy have been released in reaching the boiling point, the next increment of energy $(\Delta \mathrm{E})$ will vaporize $\Delta \mathrm{N}$ moles of uranium gas given by $\Delta N=\underline{\mathrm{E}}$

where $\mathrm{H}_{\mathrm{V}}$ is the heat of vaporization of uranium.

$$
\overline{H V}
$$

The initial volume for the gas to occupy in the core is assumed to be 5 percent of the core volume. This is an approximate value for the vold space usually present in the core. The initial amount of gas occupying this volume will therefore produce a pressure given by

$$
\mathrm{p}=\frac{\mathrm{NRT}}{\mathrm{V}}
$$

where $\mathrm{N}$ is the number of moles of gas produced, $\mathrm{R}$ is the gas constant, $\mathrm{T}$ is temperature, and $\mathrm{V}$ is volume. This pressure will cause a change in radius of the core which, it is assumed, can be evaluated by following the method of Mills (I). Using this approach, an approximate solution of the equation of motion for the change in core radius is given by

$$
\Delta r(t)=\frac{2 \gamma}{\rho r} \int_{0}^{t} \int_{0}^{t^{\prime}} p_{c}\left(t^{\prime \prime}\right) d t^{\prime \prime} d t^{\prime}
$$

where $p_{c}(t)$ is the pressure at the center of the core, $p$ is the mean density of the core, and the parameter $\gamma$, following Mills, is taken to be $1 / 3$.

The additional volume for the gas to occupy is

$$
\Delta V=4 \pi r^{2} \Delta r
$$

and the work done by the gas in expanding the core is

$$
\Delta \mathrm{W}=\mathrm{p} \Delta \mathrm{V}
$$

In succeeding time intervals, $\Delta t$, the evolved energy will be used according to

$$
\Delta \mathrm{E}=\Delta \mathrm{W}+\mathrm{H}_{\mathrm{V}} \Delta \mathrm{N}
$$

If the excursion has not been terminated by the time all of the uranium has been vaporized, part of the evolved energy will go into raising the temperature of the gas

(1) Mills, M.M. "On Hazards Due to Nuclear Reactors". TID-71

$$
\Delta \mathrm{E}=\Delta \mathrm{W}+\mathrm{C}_{\mathrm{V}} \mathrm{N} \Delta \mathrm{T}
$$

Reactor Science and Technology, Vol 1, No. 1, p. 55 
The amount of expansion required to reduce the reactor to subcriticality after an excursion depends upon $\Delta \mathrm{k} / \Delta \mathbf{r}$. This coefficient has been evaluated from multigroup diffusion calculations giving the relation $\Delta \mathrm{k} / \mathrm{k}=1.4 \Delta \mathrm{r} / \mathrm{r}$.

All the above operations are performed on the computer in a step-by-step manner, using very small time intervals which are of the order of one thousandth of the existing period. The calculation proceeds until the expansion has reduced the power level to some small value. The numerical values of the various quantities calculated can be examined for any stage of the calculation and in particular the total energy evolved can be determined.

To determine the behavior of the system when the excess reactivity is introduced gradually rather than instantaneously, the pile kinetic equations are solved in a somewhat different manner up to the point at which vaporization of the uranium begins. This is necessary because the previously given method of solution exhibits some tendency to oscillate for ramp function additions of reactivity. It is assumed that the delayed neutrons consist of a single group with an average decay constant $\bar{\lambda}$, and the multiplication constant is given as a function of time by

$$
\mathrm{k}=\mathrm{k}_{0}+4 \mathrm{t}
$$

The kinetic equations are then combined into a single second-order differential equation which is:

$$
\begin{aligned}
\frac{\mathrm{d}^{2} \mathrm{n}}{\mathrm{dt}^{2}}+ & {\left[\bar{\lambda}+\frac{1}{\ell}\left(1-\mathrm{k}_{0}+\mathrm{k}_{0} \beta\right)-\frac{\mu}{l}(1-\beta) \mathrm{t}\right] \frac{\mathrm{dn}}{\mathrm{dt}} } \\
+ & {\left[\frac{1}{\ell}\left(\bar{\lambda}-\pi \mathrm{k}_{0}-\mu+\mu \mathcal{h}-\frac{\mu \bar{\lambda}}{l}\right] \mathrm{n}=0\right.}
\end{aligned}
$$

This equation is solved on the IBM-704 computer using small time intervals, and at the same time the fission energy involved in the process is summed up until sufficient energy is accumulated (in this case $54 \mathrm{Mw}-\mathrm{sec}$ ) to begin vaporization of the uranium.

Another result is the amount of excess reactivity in the assembly at the beginning of vaporization. This calculation method is not suited for the subsequent changed in reactivity resulting from disassembly, and so at the boiling point a switch in method is made. Since the disassembly process takes place so rapidly after this point has been reached, any additional reactivity increase from the ramp function in negligible. Furthermore, if also the excess reactivity is fairly large compared to the contribution of delayed neutrons, the period at the boiling point and the subsequent history will be essentially independent of how the reactivity has been introduced. Therefore, the method for instantaneous introduction of reactivity is applicable if the initial reactivity is taken the same as already computed for the boiling point, using the ramp function, and the total energy release in the excursion can be found.

The following numerical data was used in the analysis:

$\mathrm{C}_{\mathrm{m}}$ - average specific heat of uranium metal

$C_{V}$ - specific heat of uranium gas, constant volume

$M$ - melting point of uranium

$\mathrm{H}_{\mathbf{f}}$ - heat of fusion of uranium
$3.75 \times 10^{8} \mathrm{erg} / \mathrm{C}-\mathrm{mole}$

$1.25 \times 10^{8} \mathrm{erg} / \mathrm{C}-\mathrm{mole}$

$1406 \mathrm{~K}$

$1.25 \times 10^{11} \mathrm{erg} / \mathrm{mole}$ 
$T_{B}-$ boiling point of uranium

$\mathrm{H}_{\mathrm{V}}$ - heat of vaporization of uranium

$\mathrm{H}_{\mathbf{X}}$ - heat of oxidation of uranium

$l$ - generation time of neutrons

$p$ - average density of core

$r$ - radius of core

. - number of moles of uranium $(80 \mathrm{~kg})$
$4200 \mathrm{~K}$

$3.88 \times 10^{12} \mathrm{erg} / \mathrm{mole}$

$1.25 \times 10^{13} \mathrm{erg} / \mathrm{mole}$

$6 \times 10^{-6} \mathrm{sec}$

$5.5 \mathrm{gm} / \mathrm{cm}^{3}$

$38 \mathrm{~cm}$

340 moles 


\section{B. CALCULATION OF EFFECTS ON SURROUNDING AREA}

\section{General Aspects}

For all of the dose calculations, except those for fallout and rainout, it was assumed that a radioactive cloud was released from a point source at ground level, and then moved along the ground in the shape of a hemisphere. It was further assumed that the main effect of this choice of cloud shape is to double the concentration of radioactive material in the cloud as compared to a spherical cloud of the same radius.

In the treatment of the fallout problem, it was assumed that the fission products from an excursion would emerge from the source as particulate matter capable of settling to the ground. The fission products were assumed to occur as a cloud of identically sized particles which was considered to diffuse according to the Sutton equation for an instantaneous point source, and to have a component of velocity vertically downward equal to the settling velocity of the particles. For a particular assumed height of emission above the ground (either height of rise or height of source) and a particular wind velocity, there is a unique downward component of cloud velocity that will cause the center of the cloud to strike the ground at a particular point. Each point is therefore endangered by a particular particle size and density, since these two quantities determine the settling velocity. The dose at each point has been calculated assuming that the particle size is such that the cloud center will strike the ground at that point, thereby giving the maximum fallout at that point and from that, the maximum dose.

The treatment of the rainout problem parallels that described in AECU 3066, "Meteorology and Atomic Energy", in which it is assumed that material is removed from the cloud by the rain. For each distance from the source at which the rainout gamma doses were calculated, the scavenging rate (fraction of the cloud removed per unit time) which would produce the maximum deposition at that distance was used, thereby giving the maximum rainout at that distance and from that, the maximum dose.

The two weather conditions considered are the moderate lapse condition frequently caused by air moving over a relatively warm surface, and the strong inversion condition frequently caused by air moving over a relatively cold surface. Since long-time average values for the meteorological parameters describing these weather conditions at the CANEL site are not yet available, the values for those parameters that were used in the calculations are those suggested by D. Pack of the U.S. Weather Bureau and are compatible with current on-site observations. These values are given in the following table. The variation of the virtual diffusion coefficient, $C$, with wind velocity is neglected.

Suggested Values of the Wind Velocity Profile Parameter, $n$, and
the Virtual Diffusion Coefficient, $C$

\begin{tabular}{|c|c|c|}
\hline Weather Condition & n (dimensionless) & Isotropic $\mathbf{C}$ (meters) \\
\hline Mild Lapse & 0.25 & 0.18 \\
\hline Strong Inversion & 0.50 & 0.070 \\
\hline
\end{tabular}

To obtain the concentration of radioactivity in the cloud, the following description of the fission product decay was used:

Rate of beta energy release $=1.40 \mathrm{t}^{-1.2} \mathrm{Mev} /$ second-fission, $t$ seconds after fission Average energy of beta particle $=0.4 \mathrm{Mev}$ 
Rate of gamma energy release $=1.26 \mathrm{t}^{-1.2} \mathrm{Mev} / \mathrm{second}-$ fission, $t$ seconds after fission

Average energy of gamma photon $=0.7 \mathrm{Mev}$

2. External Doses from the Cloud

The integrated external gamma doses were obtained from a nomogram constructed by J.Z. Holland (1). This nomogram was constructed for a different rate of release of gamma energy than that used in this report, and so a suitable correction factor had to be applied.

The integrated external beta doses, D, were obtained from Equation 8.2 of AECU 3066, which becomes, for the units used,

$$
D=1.30 \times 10^{5} \frac{E_{e t_{0}}^{-1.2}}{\bar{u} C^{2} x_{0}^{2-n}} \quad \text { (rep) }
$$

where:

$$
\begin{aligned}
& E_{e}=\text { excursion energy, megawatt-seconds } \\
& t_{0}=\text { cloud transit time, seconds } \\
& \overline{\mathbf{u}}=\text { wind velocity, meters/second } \frac{n}{2} \\
& C=\text { virtual diffusion parameter, (meters) }
\end{aligned}
$$

3. Inhalation Doses

Inhalation of radioactive material will result in doses to the lungs from material lodged there and to other organs from material carried to them by the bloodstream. Certain organs tend to receive more significant doses because they selectively absorb elements having long-lived radioisotopes among the fission products. The organs for which doses were calculated are the lungs, bones, and the thyroid. The radioisotopes considered are listed in Fig 20 with data from NBS Handbook 52 for calculating doses to organs other than the lungs.

The inhalation of material occurs as the radioactive cloud passes by. The concentration, $\boldsymbol{\psi}$, of material in the cloud was assumed to follow the Sutton instantaneous-point-source equation. The breathing rate was taken to be 1 cubic meter per hour.

$$
x(\xi, n, v)=\frac{Q}{\pi^{3 / 2} c^{3} x_{0}^{3(2-n) / 2}} \quad \exp \left(-\frac{\xi^{2}+n^{2}+v^{2}}{c^{2} x_{0}^{2-n}}\right)
$$

where $Q$ is the source term and $\xi, \eta$ and $U$ are measured from the center of the cloud.

The integral of the concentration multiplied by the breathing rate will give the total amount of material inhaled as the cloud passes. Suitable biological and physical factors must be introduced to take into account retention of material in organs, physical decay rates, biological elimination rates, etc. Actually, inhaled material is transferred from the lungs to various organs over a period of several days. For the purposes of these calculations, it was assumed that it is transferred immediately upon inhalation; therefore, the calculated doses and quantities received by the organs are over-estimations, especially if the doses are contributed by radioisotopes with short half-lives. For instance, if the effect of the $I^{135}\left(T_{1 / 2}=6.68 \mathrm{hr}\right.$ ) is neglected, the doses to the thyroid (table of III, $D, 3$ )

(1) Meteorology and Atomic Energy, AECU 3066, p. 104. 


\section{RADIOISOTOPES AND ORGANS CONSIDERED IN DETERMINING THE INHALATION DOSES}

\begin{tabular}{|c|c|c|c|c|c|c|c|}
\hline Organ & Radioisotope & $\begin{array}{c}\text { Fission } \\
\text { Yield } \\
100 \mathrm{y}, \% \\
\end{array}$ & $\begin{array}{c}\text { Energy Absorbed } \\
\text { in Organ per } \\
\text { Disintegration, } \\
\sum \mathrm{bE} \text {, mev } \\
\end{array}$ & $\begin{array}{c}\text { Physical } \\
\text { Decay } \\
\text { Constant, } \\
\lambda, \text { sec }^{-1} \\
\end{array}$ & $\begin{array}{l}\text { Effective } \\
\text { Decay } \\
\text { Constant, } \\
\mu, \text { sec }^{-1} \\
\end{array}$ & $\begin{array}{c}\text { Fraction of } \\
\text { Inhaled Activity } \\
\text { Retained in } \\
\text { Organ, } f \\
\end{array}$ & \multirow{6}{*}{$\begin{array}{l}\frac{\pi}{\sigma} \\
\approx\end{array}$} \\
\hline Bone & $\mathrm{Sr}^{89}$ & 4.6 & 0.55 & $1.5 \times 10^{-7}$ & $1.5 \times 10^{-7}$ & 0.22 & \\
\hline \multirow[t]{4}{*}{ (mass $=7000$ grams) } & $\mathrm{Sr}^{90}+\mathrm{Y}^{90}$ & $\mathbf{5 . 0}$ & 1.0 & $8.8 \times 10^{-10}$ & $3.0 \times 10^{-9}$ & 0.22 & \\
\hline & $\mathrm{Y}^{91}$ & 5.9 & 0.57 & $1.4 \times 10^{-7}$ & $1.6 \times 10^{-7}$ & 0.14 & \\
\hline & $\mathrm{Bd}^{140}+\mathrm{La}^{140}$ & 6.2 & 1.1 & $6.3 \times 10^{-7}$ & $6.7 \times 10^{-7}$ & 0.20 & \\
\hline & $\mathrm{Ce}^{144}+\mathrm{Pr}^{144}$ & 5.3 & 1.3 & $2.9 \times 10^{-8}$ & $4.5 \times 10^{-8}$ & 0.10 & \\
\hline Thyroid & $1^{131}$ & 3.0 & 0.22 & $1.0 \times 10^{-6}$ & $1.1 \times 10^{-6}$ & 0.15 & \\
\hline (mass $=20$ grams) & $1^{133}$ & 6.5 & 0.43 & $9.3 \times 10^{-6}$ & $9.3 \times 10^{-6}$ & 0.15 & \\
\hline & $I^{135}$ & 5.9 & 0.32 & $2.9 \times 10^{-5}$ & $2.9 \times 10^{-5}$ & 0.15 & \\
\hline
\end{tabular}


may be reduced by one third. The three equations concerned with inhalation doses were derived utilizing these assumptions and conditions.

The inhalation dose, $D$, to an organ from a particular radioisotope was calculated using the equation:

$$
\mathrm{D}=9.7 \times 10^{4} \frac{\operatorname{Eefy}\left(\sum \mathrm{bE}\right) \lambda \exp \left(-\lambda \mathrm{t}_{\mathrm{o}}\right)}{\mathrm{uC}^{2} \mathrm{x}_{\mathrm{o}}^{2-n_{\mathrm{m}} / 4}}
$$

where:

$m=$ mass of the organ, grams

$f=$ fraction of inhaled quantity of radioisotope retained in the organ

$y$ = average yield of radioisotope per fission

$\lambda=$ physical decay constant of radioisotope, seconds $^{-1}$

$\psi=$ effective decay constant of radioisotope while in body, taking excretion into account, seconds ${ }^{-1}$

The inhalation dose to the lungs was calculated on the basis of retention of 12 percent of all the short-lived radioisotopes inhaled and the mass of the lungs being 1 kilogram. The equation used to calculate this dose, $D$, is

$$
\mathrm{D}=1.51 \times 10^{3} \frac{\mathrm{E}_{\mathrm{et}}{ }^{-0.2}}{\mathrm{u} \mathrm{C}^{2} \mathrm{x}_{\mathrm{o}}{ }^{2-\mathrm{n}}}
$$

The equation used to calculate the amount, $A$, of a radioisotope initially retained in the thyroid or the bone is

$$
A=1.49 \times 10^{8} \frac{E_{e f y} \lambda}{\bar{u} C^{2} x_{o}^{2-n}} \exp \left(-\lambda t_{o}\right) \text { (microcuries) }
$$

The wind velocity chosen for calculations using Equation (4) is 6 meters per second, a value representative of the average maximum wind velocity at the CANEL site.

4. External Doses from Fallout and Rainout

From the Sutton equation for the concentration from an instantaneous point source, the following equation for the fallout deposition was obtained:

$$
\omega=\frac{H Q}{C^{2} x_{0}^{3-n}} \exp \left(\frac{-\eta^{2}}{c^{2} x_{0}^{2-n}}\right) \quad\left(\frac{\text { activity }}{\text { unit area }}\right) \text {, }
$$

where $H$ is the height of emission. This equation is completely valid only if $x_{0}{ }^{2} \gg H^{2}$, a condition that holds for all the fallout calculations of this report.

An expression for the external beta dose from fallout was developed from Equation (6) in the following manner. The dose from the primary beta particles will be very large a few feet above the ground, but will be relatively small 15 or 20 feet above the ground. The average range for these beta particles is about 5 feet of air. Assuming that the upwardly directed beta energy is absorbed uniformly in the first 5 feet of air above the ground, or that the total energy is deposited in a cylinder of air five feet high, the energy 
absorbed per gram of air may be calculated and then related to a body dose. The expression obtained for the fallout beta dose, $D$, is

$$
D=6.72 \times 10^{5} \cdot \frac{E_{e t} t_{0}^{-0.2}}{C^{2} x_{0}{ }^{3-n}}
$$

An expression for the external gamma-dose from fallout was developed from Equation (6) in the following manner. It was assumed that for the distances for which doses are calculated, the main part of the material deposited is close enough to the proposed absorber that attenuation may be neglected. Then, the total gamma-ray flux from all the material deposited was obtained for a point I meter above the ground impact point. From this, the following expression for the fallout gamma-dose, D, was obtained,

$D=1.81 \times 10^{4} \frac{E^{2} t_{0}^{-0.2}}{C^{2} x_{0}{ }^{3-n}} \quad \exp \left(\frac{1}{2 C^{2} x_{0}{ }^{2-n}}\right) \quad K_{0}\left(\frac{1}{2 C^{2} x_{o}^{2-n}}\right) \quad$ (rem)

where $K_{0}$ is a zero-order Bessel function of the second kind.

The external gamma dose from rainout was obtained for a deposition of the type expressed by Equation (7.21) of AECU 3066, which is

$$
\omega=\frac{\mathrm{Q}}{\mathrm{e} \pi^{1 / 2} \mathrm{Cx}_{\mathrm{o}}(4-\mathrm{n}) / 2} \quad\left(\frac{\text { activity }}{\text { unit area }}\right)
$$

The expression for the rainout gamma-dose, D, was obtained from Equation (9) in the same manner as Equation (8) was obtained from Equation (6), and is

$\mathrm{D}=5.54 \times 10^{2} \frac{\mathrm{Eet}_{\mathrm{o}}^{-0.2}}{\mathrm{u} \mathrm{Cx}_{\mathrm{o}}{ }^{(4-\mathrm{n}) / 2}} \exp \left(\frac{1}{2 \mathrm{C}^{2} \mathrm{x}_{\mathrm{o}}^{2-\mathrm{n}}}\right) \quad \mathrm{K}_{\mathrm{o}}\left(\frac{1}{2 \mathrm{C}^{2} \mathrm{x}_{0}^{2-\mathrm{n}}}\right) \quad$ (rem)

Equations (7), (8), and (10) are for infinite exposure time. If the exposure time is less (due to evacuation, decontamination, etc.), the resulting dose is less and may be obtained from Fig 21 in terms of the infinite exposure time dose. For example, if the exposure time is one-half hour at a distance of 2640 feet and the wind velocity is 10 meters per second, the gamma fallout dose will be $0.46 \cdot 26 \mathrm{rem}=12 \mathrm{rem}$. 
FRACTION OF INFINITE-TIME DOSE RECEIVED FOR FINITE EXPOSURE TIMES

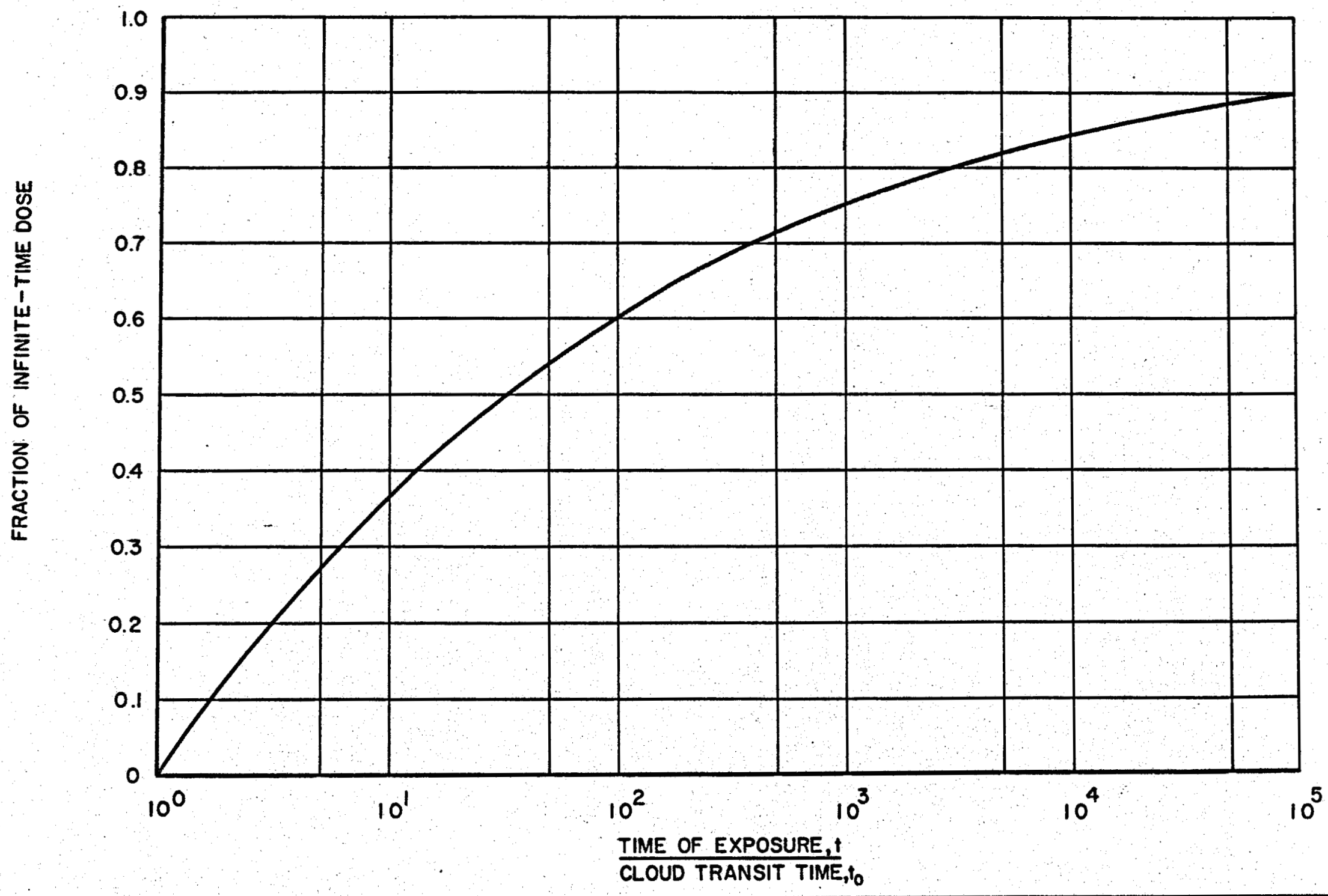

TIME OF EXPOSURE 


\section{INDUSTRIES ADJACENT TO SITE}

Information published in 1954 by the Labor Department of the State of Connecticut has been used to determine the amount, kind, and distribution of industrial activity within a ten-mile radius of the site. Fig 22 lists the number of workers at each geographical location within this region. Fig 23 gives the number of workers employed by each kind of industry found in the region. Fig 24 lists the number of workers and location of every industrial establishment situated within the region. 
LISTING OF LABOR MARKET AREAS (SHOWING CITIES \& TOWNS)

THAT FALL WITHIN 10 MILE RADIUS OF SITE

Local Market Area

Hartford

Middletown

Norwich

New Haven

Meriden

New Britain
Town

Rocky Hill

South Glastonbury

Hopewell

Middletown

Portland

Cromwell

East Hampton

Marlborough

Gildersleeve

Newfield

Westfield

Highland

Baileyville

Cobalt

East Meriden

Middle Haddam

Rockfall

Middlefield

Haddam Neck

Bashan

Haddam

Leesville

Higganum

Durham

Durham Center

Moodus

Ponset

Shailerville

Little Haddam

Tylerville

East Haddam

Westchester

North Westchester

East Berlin
Industrial Workers

390

150

No Industry

5,975

1,925

190

820

No Industry 35

No Industry

No Industry

No Industry

No Industry

No Industry

No Industry

No Industry

30

190

No Industry

No Industry

95

No Industry

75

240

30

60

No Industry

No Industry

No Industry

No Industry

225

No Industry

No Industry

No Industry

No Industry

225 


\section{SUMMARY OF INDUSTRIAL WORKERS WITHIN 10 MILE RADIUS}

OF SITE BY TYPE OF INDUSTRY AND AREA

Type of Industry

Ordnance

Food

Textiles

Apparel

Lumber \& Wood

Furniture \& Fixtures

Paper

Printing \& Publishing

Chemicals

Products of Petroleum \& Coal

Rubber

Stone, Clay \& Glass

Primary Metals

Fabricated Metals

Machinery

Electrical Equipment

Transportation Equipment

Misc. Manufacturing Industries

Auto Repair Shops

TOTALS
Middletown

Hartford

$-$

$\begin{array}{r}150 \\ 70 \\ 1,465 \\ 495 \\ 40 \\ 70 \\ 855 \\ 240 \\ 195 \\ 30 \\ 960 \\ 205 \\ 240 \\ 1,365 \\ 1,215 \\ 450 \\ 870 \\ 845 \\ 130 \\ \hline 9\end{array}$

$--$

$-$

$--$

5

150

$-$

5

35

150

$-$

40

5

$-$

$-$

$+$

540
New Britain

Totals

$\therefore$

$--$

$-$

$-$ 


\section{LOCATED WITHIN A IO-MILE RADIUS OF THE SITE}

INDUSTRY

Textiles

Food

Auto Repalr Shops

Jackson Chevrolet

Jackson Motor Co.

W. B. Nichols Garage

W. B. Nhols Garage

Machinery J. C. Barton Co.

Clark Harrow Co.

Cromwell Mach. Corp.

DuMond Gun Co.

Emhart-St'd Knapp Div

C. G. Garrigus Co.

L. M. Gowtn Mfg.

Johnison Mfg, Co.

Machine Design Shop

Materials Mfg, Corp.

Middlesex Bng. \& Mfg. Co.

Middletown Grinding Servtce

Modern Mech. \& Scientific Lab.

Parker Balley Mfg. Co.

L. L. Sweet

Electroweave Mfg. Co.

Haddam MIg. Co.

The Newton Co.

Raymond Eng. La

Ripley Co., lic.

Viking Instrument, Inc.

LOCATION NO, EMPLOYEES INDUSTRY

East Hampton

Moodus

Middletown

East Hampton
Middletown

Moodus

East Hampton

Moodus

Middletown

Middletown

East Haddam

East Hampton

Middletown

Middletown

Middletown

Middletown

Middietown

Middletown

Middletown

Moodus

Middletown

East Hampton

Hlgganum
Cromwell

East Hampton

Portland

Haddam

Middletown

Middletown

Middletown

Moodus

Middletown

Middlefield

Middletown

Higganum

Cromwell

Electrical

Transportation

Equipment

Alcap Mfg. Co.. Inc.

Eis Automotive Corp.

Hetrick Mfg. Co.

Holter's Yacht Yard

Mastercraft Tratler

Portland Boat Works

Safeway Heat Elements

Fabricated Metal

Auto Heat Corp.

Auto Machine Products

artlatic Wire Producto

Julius Carlson

Clairglow Mfg. Co

B. Hampton Finishing Co

Bastern Wire Product

Bcono Wroducts

Hillside Widg. Ornamental Works

Johnson Blectroplating Co

Liteway Mfg. Corp.

Lord Hodge

Middletown Bress $\mathrm{Co}$

Middletown M(g. Co.

Middletown wire Products

Mohawk Mfg. Co.

Organtc Finishing Co.

J. A. Otterbein

Prime Sheet Metal Co

Rayco Products, Inc.

Robot Auto Heat Corp.

D. H. Scovll, Inc.

United Spectalist Co.

Wiled Specialista Corp.

Chemicals

American Distlling Co.

Duilte Chemical Corp.

Synorganic Products

Worth Spar Co., Inc.
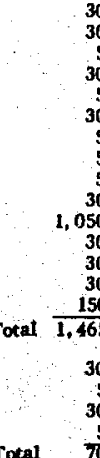

Indestrles

Rubber

Apparel

Haddam

Haddam

Middletown

Middletown

Middletown

East Hadda

Paper

Middletown

Mildletown

Portland

Middletow

Middletown

Middletown

Middletown

Middletown

Middletown

Bast Hampto

Mtddletow

Portland

East Hampton

Meddiom

Mast Hadda

Middetown

East Hampton

Middletown

Middletown

Durham

Middletown

Middletown

Middletown

Middletown

Middletown

Middletown

Middletown

Mlddetown

Middletown

Higganum
Middlefteld

Haddam

Middletown

Bast Hampton

Middletow

Portland

Portland

Middletow
Primary Metals

Misc. Manufactu

Stone, Clay and Glas

(Middletow

Wilber Bhlers

General Woodworking Co.

J. T. Rossi

A1rex, Inc

Goodrear Rubber Co.

Middletown Rubber Corp.

Auburn Mtg. Co.

Carwin House, Inc.

Conn. Asbestos Products

Cromwell Concrete Product

Mureka Mica Mining Co.

Middlesex Septic Tank Co.

Bevin Bros. Mfg. Co.

W.H. Chapman C

H.R. Bng. Lab.
Starr Bros. Bell Co

A. Brozek Co.

Frizmar, Inc.

Gong Bell MIg. Co

N H.HIL Brass Co.

Middleaex Silver Co

Philson Induatries

Remlngton Rand

Rogers Mfg. Co.

J. E. Stevens Co,

Buckner Process Co.

James Caruso

Charlein Coats, Ltd.

Harlow Producte Corp

Lyngrace Mfg, Corp.

Naomi Dress.

Printing Publishing Art-Gravure

E. Hampton News

E. Hampton News
Ideal Printing Co.

Kensington Press, Inc

Middletown Press Co.

Scanion Bros.

Stewart Press

Waverly Printing Co.

Young Co.

Carpenter Hayes Paper Box Co. East Hampton

Robert Gair Co. Portland

Jackson Corrugated Cont. Corp. Middletown
East Haddam

W. H. Reinhold

Middletown
R. D. Ward Co.

Mortland:

Total $\frac{150}{450}$

Furntture Fixtures

Charles $w$. Chase

N. B. Shade \& Blind Co

W. A. Parsons Co.

East Hampton

Durham

Durham

Middletown

Products of Petroleum Anderson Oil Co.

\& Coal

Ordnance

Lyman Gunsight Corp.

(Hartford Labor Market Area)

Textiles Matson Mill, inc

Chemicals

Rubber

Hartford Rayon Corp.

O.K. Rubber Welders

Stone, Clay \& Glass

Blmore Co

Rocky Hill Vault Co

Primary Metals Conn. Foundry Co.

Machinery

C.S.,W. Plastic Type日, Inc

Gute Tool \& Engraving Co

Saber Exper. Tool Co.

Electrical Equipment Advanced Electronics, Inc.

(New Britaln Labor Market Area)

Lumber Wood Aldon's Woodworking

Chemicala Stanley Chemical Co.

Stone, Clay 4 Glass Eastern Brick Co.

Primary Metals

Fabricated Metals

New Britain Die Cast Corp

Preclaion Procesaing

Kelsey Mfg. Co.
Printing \& Publishing Stecher Traung Lith. Corp.

Portland Middletown

etown

Middletown

Bast Hadda

Cromwell

Portland

Portland

Bast Hampto

Bast Haddam

Bast Hampton

Moodus

ast Hampton

Middletown

Middletow

Cromwell

Middletown

iddletown

Middletown

dd detown

Middletown

Migganum 


\section{METEOROLOGY}

\section{Introduction}

Information following was prepared by the Scientific Services Division, U.S. Weather Bureau, Washington, D.C.

This site is located on the west bank of the Connecticut River approximately 5 miles east-southeast of Middletown, Connecticut, and 20 miles south-southeast of Hartford, Connecticut. Long Island Sound is approximately due south of the site. The facility site proper is on a small relatively flat plateau approximately 100 feet above the river level. This plateau is surrounded by rough, hilly terrain with tops of the larger hills three to four hundred feet above the plateau level.

2. Source of Data

a. Although only limited data exist for the site itself, quite complete meteorological data have been taken for many years at Hartford, Connecticut. Even considering the probable influence of the rough terrain on wind patterns at the site (estimated differences will be discussed in a later section), the major climatic features of the proposed site may be satisfactorily defined by the Hartford records. Fig 25 is a copy of the 1956 Local Climatological Data for Hartford, Connecticut.

b. Since late March, 1956, an extensive meteorological data collection program has been in operation at the site.

This program consists of the continuous recording of the following parameters:

Temperature (ambient) - 5-foot level of tower

Dew Point - 5-foot level

Wet Bulb - 5-foot level

Temperature Difference -5 to 50 feet

Temperature Difference - 5 to 150 feet

Temperature Difference - 5 to 200 feet

Wind Direction - 15-foot level

Wind Speed - 15-foot level

Wind Direction - 200-foot level

Wind Speed - 200-foot level

Direction Deviation - 200-foot level

Gustiness - 200-foot level

Speed Deviation - 200-foot level

Precipitation

The following parameters are recording during the weekday daylight hours:

Sky Cover 


\section{U. S. DEPARTMENT OF COMMERCE WEATHER BUREAU}

\section{LOCAL CLIMATOLOGICAL DATA WITH COMPARATIVE DATA}

\section{6}

\section{HARTFORD, CONNECTICUT}

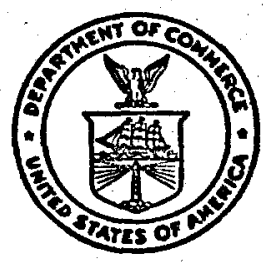

\section{MARRATIVE CLIMATOLOGICAL SUMMARY}

Bradley Fleld Is located about 3 miles vest of the Connectlcut R1ver on allght rlse on ground in a broad portion of the Connecticut RIver Velley between NorthBouth mountain ranges whose height do not exceed 1200 toet.

The station's lat1tude ( $41^{\circ}$ 56. M) places 1 tell ingide the northern temperature climatic zone in a prevailing west to exis movement of alr carrying the mejority of weather systews into connecticut from the west. The average vinter-tiwe position of the "Polar' Front" boundary between cold dry poler air and wars molst troptcul 1s just south of Nor knglend, whiob haips to explain the extensive winter atorn activity and day to day variability oxtensive winter atorm activity and day to day variability or local westher in euwer, the "Polar Front" has an avthis station in a wark and pleasent atmosphere.

The location of Hartford, relative to continent and ocean 1s also Igniflcant. Hap1d wenther changes reault when torms move northrard along the Mid-Atlant 1c coast, frequent1s producing trong and persistent north-east inda quentiy producing trong and persistent north-east northeasterm. Seasonaliy, weather characteristica vary northerster.; seasonal1y, menther characteriatica vary the rarm, maritimo alr of aummer, the one from canada, the other from the Gulf of Mexico, Caribbean Sea or AtIantic Ocave summer thunderstorms develop in the Berkshire Hountatns to the rest and northrest, nove over the connecticut Valley and when acoompanied by find and hall, sometimes cause constderable damage to crops, particularly tobacco. During the winter, xain often fails through cold atr trapped in the vailey, creating extremely hazardous tce conditions. On clear, nights in the late summer or enriy eutumn, cool alx dralnage lnto the valley and molsture from the Connecticut R17er produce ateam and/or ground fog which becomes quite dense throughout the valley hampering ground and alr transportation.

Mean monthly temperatures range from 26 degrees in late January and early February to 75 degrees in July. Absolute extremes are 101 degrees, september, 1953 and -24 degrees, February, 1843. The average dally temperature variation 1s 18 degrees with the grentest in mid-spring and atdeutumn. The mean date of the last k1111ng frost 18 April 19th, and the first, Dctober 17th. The mean length of the growing gerson is 181 days; the shortest being 130 days in 1917 and the longest 21 days in 1020 . The prevaling and direction is valing wind direction is aoutherly for the summer months and norther1y during the rinter. The average annus August 1955, Fith 21.87 1nches and the driest, October, 1824 with 0.18 of en inch. 
LATTUDE $41^{*} 36^{\circ} \times$

LONGITUDE $72^{\circ} 41^{\circ}$.

METEOROLOGICAL DATA FOR THE CURRENT YEAR

HARTRORD, COMMECTYCOT

ELEVATION (ground) 169 teet

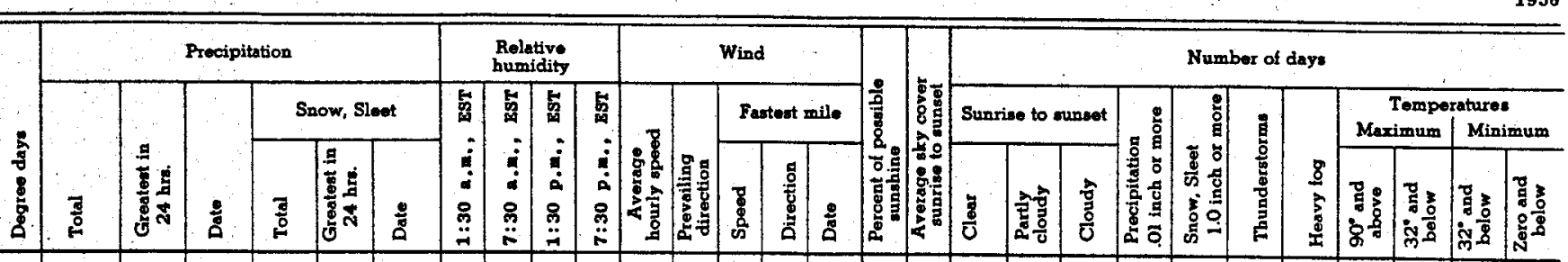

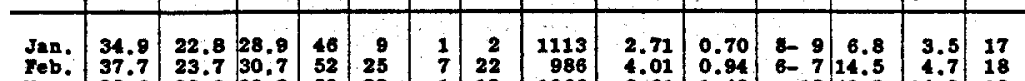

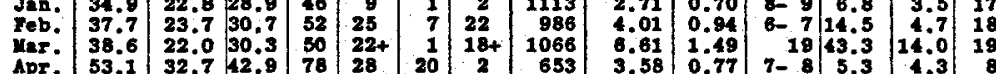

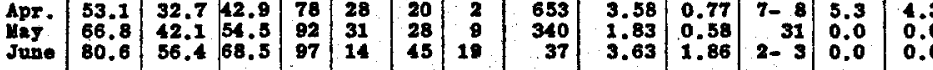

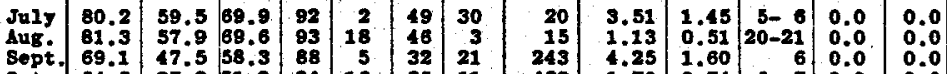

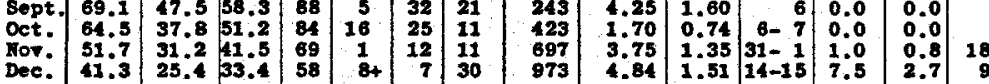

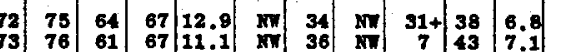

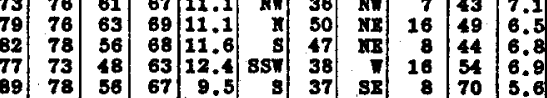

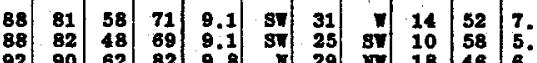

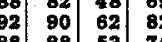

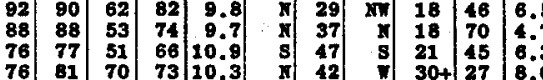

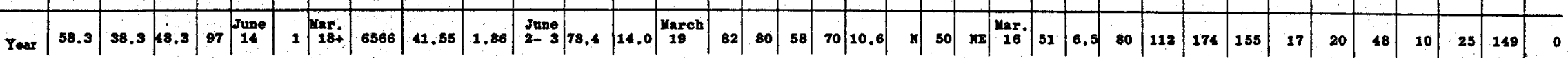

NORMALS, MEANS, AND EXTREMES
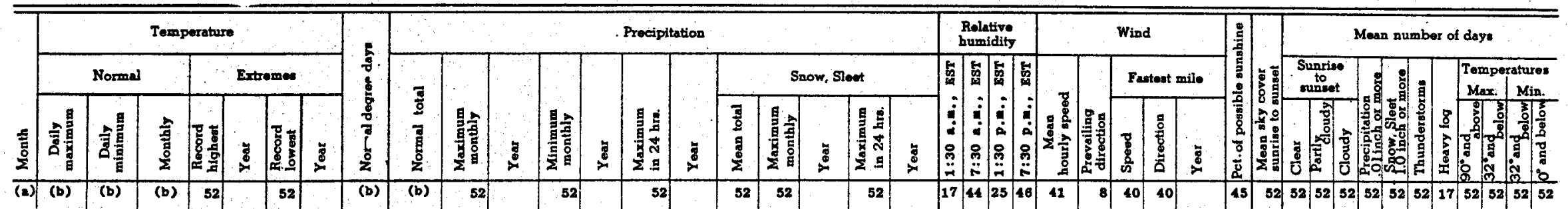

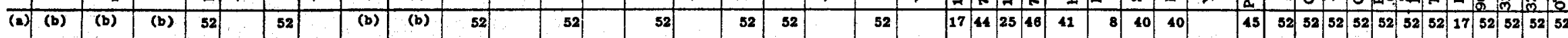

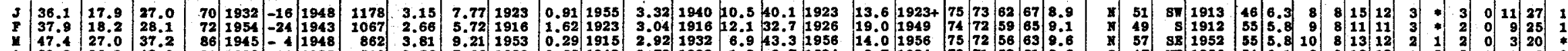

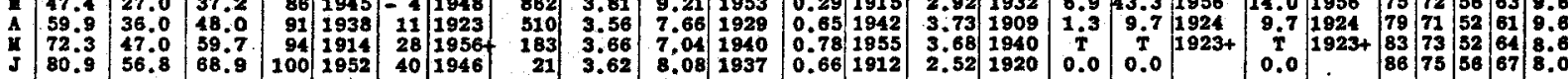

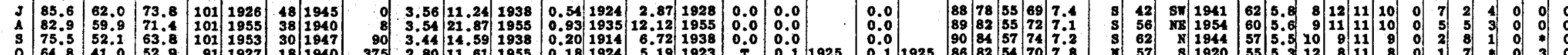

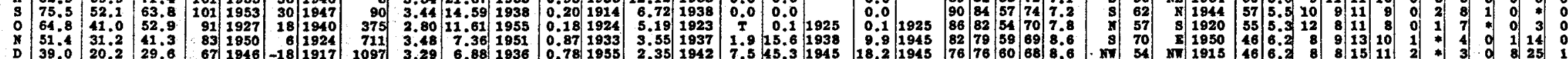

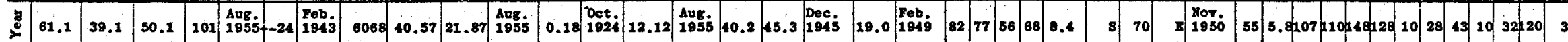
erremeres yorrs

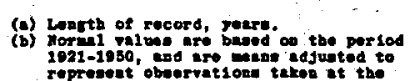

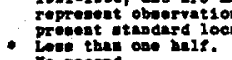

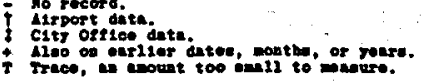

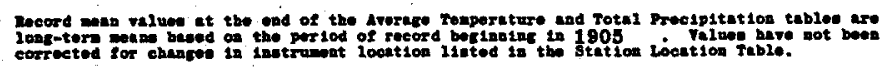

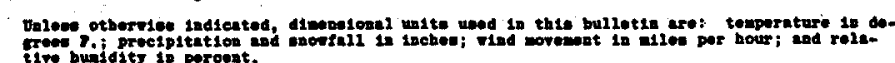

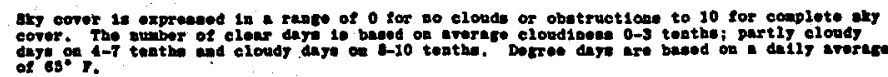

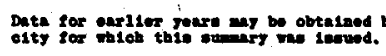

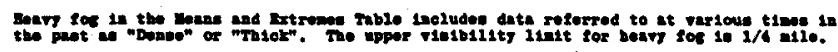

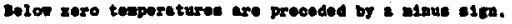

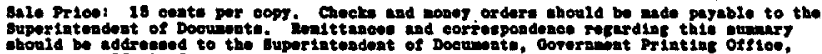


MONTHLY AND SEASONAL SNOWFALL

EARTORD, CONRECTYCU:

\begin{tabular}{|c|c|c|c|c|c|c|c|c|c|c|c|c|c|}
\hline Soavon & July & Aug. & Sent. & Oet. & Nor. & Dec. & Jan. & Pab. & Mar. & Apr. & May & June & Total \\
\hline $\begin{array}{l}1934-35 \\
1935-36 \\
1936-37 \\
1937-38 \\
1938-38\end{array}$ & $\begin{array}{l}0 \\
0 \\
0 \\
0 \\
0\end{array}$ & $\begin{array}{l}0 \\
0 \\
0 \\
0 \\
0\end{array}$ & $\begin{array}{l}0 \\
0 \\
0 \\
0 \\
0\end{array}$ & $\begin{array}{l}\mathbf{T} \\
0 \\
0 \\
0 \\
0\end{array}$ & $\begin{array}{r}1 \\
1.7 \\
2.8 \\
1.8 \\
18.6\end{array}$ & $\begin{array}{l}0.3 \\
0.8 \\
0.9 \\
2.1 \\
1.4\end{array}$ & $\begin{array}{l}20.1 \\
15.2 \\
4.2 \\
23.6 \\
11.8\end{array}$ & $\begin{array}{r}15.3 \\
12.8 \\
0.8 \\
7.9 \\
0.6\end{array}$ & $\begin{array}{r}4.2 \\
5.5 \\
5.0 \\
1.6 \\
15.2\end{array}$ & $\begin{array}{l}1.2 \\
T \\
0.8 \\
3.3 \\
1.0\end{array}$ & $\begin{array}{l}0 \\
0 \\
0 \\
0 \\
0\end{array}$ & $\begin{array}{l}0 \\
0 \\
0 \\
0 \\
0\end{array}$ & $\begin{array}{l}14.1 \\
39.1 \\
14.7 \\
40.3 \\
56.6\end{array}$ \\
\hline $\begin{array}{l}1939-40 \\
1940-41 \\
1941-42 \\
1942-43 \\
1943-44\end{array}$ & $\begin{array}{l}0 \\
0 \\
0 \\
0 \\
0\end{array}$ & $\begin{array}{l}0 \\
0 \\
0 \\
0\end{array}$ & $\begin{array}{l}0 \\
0 \\
0 \\
0 \\
0\end{array}$ & $\begin{array}{l}0 \\
T \\
0 \\
0 \\
0\end{array}$ & 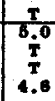 & $\begin{array}{r}9.3 \\
1.1 \\
1.0 \\
10.2 \\
0.4\end{array}$ & $\begin{array}{r}7.7 \\
10.3 \\
7.1 \\
18.6 \\
0.7\end{array}$ & $\begin{array}{r}16.9 \\
1.9 \\
5.7 \\
8.5 \\
8.8\end{array}$ & $\begin{array}{r}3.9 \\
18.7 \\
2.3 \\
0.6 \\
12.2\end{array}$ & $\begin{array}{c}1.7 \\
0 \\
0.5 \\
0.1 \\
T\end{array}$ & $\begin{array}{l}0 \\
0 \\
0 \\
0 \\
0\end{array}$ & $\begin{array}{l}0 \\
0 \\
: \\
0 \\
0\end{array}$ & $\begin{array}{l}41.8 \\
10.0 \\
16.6 \\
48.0 \\
26.8\end{array}$ \\
\hline $\begin{array}{l}1944-45 \\
1945-46 \\
1946-47 \\
1947-48 \\
1948-49\end{array}$ & $\begin{array}{l}0 \\
0 \\
0 \\
0 \\
0\end{array}$ & $\begin{array}{l}0 \\
0 \\
0 \\
0 \\
0\end{array}$ & $\begin{array}{l}0 \\
0 \\
0 \\
0 \\
0\end{array}$ & $\begin{array}{l}0 \\
0 \\
0 \\
0 \\
0\end{array}$ & $\begin{array}{r}6.6 \\
10.0 \\
0.2 \\
0.4 \\
1.7\end{array}$ & $\begin{array}{r}12.9 \\
45.3 \\
5.1 \\
29.9 \\
13.2\end{array}$ & $\begin{array}{r}20.1 \\
10.2 \\
6.3 \\
27.6 \\
16.4\end{array}$ & $\begin{array}{l}24.3 \\
13.8 \\
18.7 \\
15.0 \\
13.4\end{array}$ & $\begin{array}{r}9.9 \\
0.9 \\
11.8 \\
15.8\end{array}$ & $\begin{array}{c}0 \\
0.0 \\
0.7 \\
0 \\
0\end{array}$ & $\begin{array}{l}0 \\
0 \\
0 \\
0 \\
0\end{array}$ & $\begin{array}{l}0 \\
0 \\
0 \\
0 \\
0\end{array}$ & $\begin{array}{l}66.8 \\
79.9 \\
33.0 \\
77.7 \\
60.5\end{array}$ \\
\hline $\begin{array}{l}1949-50 \\
1950-51 \\
1951-52 \\
1952-53 \\
1953-64\end{array}$ & $\begin{array}{l}0 \\
0 \\
0 \\
0 \\
0\end{array}$ & $\begin{array}{l}0 \\
0 \\
0 \\
0 \\
0\end{array}$ & $\begin{array}{l}0 \\
0 \\
0 \\
0\end{array}$ & $\begin{array}{l}0 \\
0 \\
0 \\
\mathbf{T} \\
0\end{array}$ & $\begin{array}{r}3.9 \\
\mathbf{7} \\
0.6 \\
0.3 \\
1.9\end{array}$ & $\begin{array}{r}12.6 \\
7.4 \\
8.7 \\
2.2 \\
0.1 \\
\end{array}$ & $\begin{array}{r}3.6 \\
12.3 \\
16.3 \\
16.4 \\
17.1 \\
\end{array}$ & $\begin{array}{r}18.9 \\
6.1 \\
16.1 \\
6.8 \\
1.1 \\
\end{array}$ & $\begin{array}{r}5.6 \\
11.3 \\
4.3 \\
T \\
T\end{array}$ & $\begin{array}{c}4.7 \\
0 \\
0 \\
T \\
0.3 \\
\end{array}$ & $\begin{array}{l}0 \\
0 \\
0 \\
0 \\
0\end{array}$ & $\begin{array}{l}0 \\
0 \\
0 \\
0 \\
0\end{array}$ & $\begin{array}{l}49.3 \\
37.1 \\
46.0 \\
25.4 \\
22.0\end{array}$ \\
\hline $\begin{array}{l}1954-55 \\
1955-56 \\
1956-57\end{array}$ & 0 & : & : & $\stackrel{0}{T}$ & $\begin{array}{l}0 \\
3.0 \\
1.0\end{array}$ & $\begin{array}{l}2.8 \\
9.2 \\
7.8\end{array}$ & 1.2 & 8. & & $\begin{array}{l}3.8 \\
5.3\end{array}$ & $\boldsymbol{\theta}$ & 0 & 76.1 \\
\hline
\end{tabular}

\begin{tabular}{|c|c|c|c|c|c|c|c|c|c|c|c|c|c|}
\hline Soavon & July & Aug. & Sept. & Oot: & Nor. & Doc. & $\operatorname{len}$. & Fob. & Mar. & Apr. & $\mathbf{M a y}$ & Jume & Total \\
\hline $\begin{array}{l}1904-05 \\
1905-06 \\
1906-07 \\
1907-08 \\
1908-09\end{array}$ & $\begin{array}{l}0 \\
0 \\
0 \\
0 \\
0\end{array}$ & $\begin{array}{l}\mathbf{0} \\
\mathbf{0} \\
0 \\
0 \\
0\end{array}$ & $\begin{array}{l}0 \\
0 \\
0 \\
0 \\
0\end{array}$ & $\begin{array}{l}- \\
0 \\
0 \\
0 \\
x\end{array}$ & $\begin{array}{c}\mathbf{T} \\
5.2 \\
0.2 \\
1.4\end{array}$ & $\begin{array}{r}3.6 \\
10.8 \\
12.8 \\
9.6\end{array}$ & $\begin{array}{r}27.1 \\
4.7 \\
14.6 \\
6.1 \\
9.4\end{array}$ & $\mid \begin{array}{r}10.8 \\
9.8 \\
25.8 \\
16.6 \\
1.6\end{array}$ & $\begin{array}{r}0.4 \\
15.5 \\
8.6 \\
3.6 \\
8.6\end{array}$ & $\begin{array}{l}0.1 \\
0.8 \\
0.6 \\
T \\
0.7\end{array}$ & $\begin{array}{l}\mathbf{T} \\
\mathbf{0} \\
\mathbf{z} \\
\mathbf{0} \\
\mathbf{0}\end{array}$ & $\begin{array}{l}0 \\
0 \\
0 \\
0 \\
0\end{array}$ & $\begin{array}{l}34.5 \\
70.6 \\
38.3 \\
31.3\end{array}$ \\
\hline $\begin{array}{l}1909-10 \\
1910-11 \\
1911-12 \\
1912-13 \\
1913-14\end{array}$ & $\begin{array}{l}0 \\
0 \\
0 \\
0 \\
0\end{array}$ & $\begin{array}{l}0 \\
0 \\
0 \\
0 \\
0\end{array}$ & $\begin{array}{l}0 \\
0 \\
0 \\
0 \\
0\end{array}$ & $\begin{array}{l}0 \\
: \\
0 \\
0 \\
T\end{array}$ & $\begin{array}{l}1.9 \\
3.3 \\
1.1 \\
0.5 \\
0.7\end{array}$ & $\begin{array}{r}17.5 \\
6.9 \\
4.0 \\
7.0 \\
1.8\end{array}$ & $\begin{array}{r}14.6 \\
0.5 \\
15.2 \\
0.8 \\
8.7\end{array}$ & $\begin{array}{r}12.2 \\
14.8 \\
0.1 \\
9.3 \\
27.8\end{array}$ & $\begin{array}{r}0.2 \\
6.8 \\
10.6 \\
2.1 \\
8.9\end{array}$ & $\begin{array}{l}0.2 \\
4.7 \\
T \\
T \\
T\end{array}$ & $\begin{array}{l}0 \\
: \\
0 \\
0 \\
0\end{array}$ & $\begin{array}{l}0 \\
0 \\
0 \\
0 \\
0\end{array}$ & $\begin{array}{l}46.6 \\
35.8 \\
30.8 \\
19.7 \\
41.6\end{array}$ \\
\hline $\begin{array}{l}1914-16 \\
1915-16 \\
1916-17 \\
1917-18 \\
1018-19\end{array}$ & $\begin{array}{l}0 \\
: \\
: \\
0\end{array}$ & $\begin{array}{l}0 \\
0 \\
0 \\
0 \\
0\end{array}$ & $\begin{array}{l}0 \\
0 \\
0 \\
0 \\
0\end{array}$ & $\begin{array}{l}T \\
7 \\
0 \\
0 \\
0\end{array}$ & $\begin{array}{c}4.5 \\
T \\
0.6 \\
0.4 \\
T\end{array}$ & $\begin{array}{r}2.5 \\
20.0 \\
6.8 \\
13.7 \\
4.2\end{array}$ & $\begin{array}{r}7.4 \\
1.8 \\
7.8 \\
13.2 \\
1.1\end{array}$ & $\begin{array}{r}3.0 \\
24.6 \\
12.4 \\
5.8 \\
8.5\end{array}$ & $\begin{array}{r}1.0 \\
27.4 \\
7.2 \\
7.0 \\
3.4\end{array}$ & $\mid \begin{array}{l}7.5 \\
3.3 \\
0.4 \\
4.5 \\
7\end{array}$ & $\begin{array}{l}0 \\
0 \\
\mathbf{T} \\
0 \\
0\end{array}$ & $\begin{array}{l}0 \\
0 \\
0 \\
0 \\
0\end{array}$ & \begin{tabular}{|l|}
25.9 \\
77.1 \\
35.3 \\
44.8 \\
17.2
\end{tabular} \\
\hline $\begin{array}{l}1919-20 \\
1920-21 \\
1921-22 \\
1922-23 \\
1923-24\end{array}$ & $\begin{array}{l}0 \\
0 \\
0 \\
0 \\
0\end{array}$ & $\begin{array}{l}0 \\
0 \\
0 \\
0 \\
0\end{array}$ & $\begin{array}{l}0 \\
0 \\
0 \\
0 \\
0\end{array}$ & $\begin{array}{l}0 \\
: \\
0 \\
0 \\
0\end{array}$ & $\begin{array}{c}T \\
T \\
T \\
0.5\end{array}$ & $\begin{array}{r}2.8 \\
2.8 \\
1.4 \\
12.1 \\
7.1\end{array}$ & $\begin{array}{r}18.8 \\
2.3 \\
6.8 \\
40.1 \\
4.0\end{array}$ & $\begin{array}{r}24.6 \\
21.2 \\
11.0 \\
13.1 \\
2.7\end{array}$ & $\left|\begin{array}{c}10.0 \\
T \\
5.8 \\
3.8 \\
4.2\end{array}\right|$ & $\begin{array}{l}0.1 \\
T \\
1.7 \\
0.2 \\
9.7\end{array}$ & $\begin{array}{l}\mathbf{0} \\
\mathbf{0} \\
\mathbf{0} \\
\mathbf{0} \\
\text { 0 }\end{array}$ & $\begin{array}{l}0 \\
: \\
0 \\
0 \\
0\end{array}$ & $\begin{array}{l}83.3 \\
26.1 \\
26.8 \\
69.8 \\
27.7\end{array}$ \\
\hline $\begin{array}{l}1924-25 \\
1925-26 \\
1826-27 \\
1927-28 \\
1028-29\end{array}$ & $\begin{array}{l}0 \\
0 \\
0 \\
0\end{array}$ & $\begin{array}{l}0 \\
0 \\
0 \\
0\end{array}$ & $\begin{array}{l}0 \\
0 \\
0 \\
0\end{array}$ & $\begin{array}{c}0 \\
0.1 \\
T \\
0 \\
T\end{array}$ & ${ }^{0.0}$ & $\mid \begin{array}{r}0.5 \\
3.0 \\
30.7 \\
\mathbf{T} \\
0.4\end{array}$ & $\mid \begin{array}{r}17.3 \\
8.2 \\
12.7 \\
4.8 \\
10.7\end{array}$ & $\begin{array}{r}0.1 \\
32.7 \\
8.6 \\
7.8 \\
0.8\end{array}$ & $\begin{array}{l}0.2 \\
1.6 \\
2.1 \\
7.0 \\
3.0\end{array}$ & $\begin{array}{c}T \\
0.1 \\
T \\
1.0\end{array}$ & $\begin{array}{l}0 \\
0 \\
0 \\
0 \\
0\end{array}$ & $\begin{array}{l}0 \\
0 \\
0 \\
0 \\
0\end{array}$ & $\begin{array}{l}19.0 \\
45: 7 \\
14.1 \\
20.5 \\
26.8\end{array}$ \\
\hline $\begin{array}{l}1929-30 \\
1930-31 \\
1931-32 \\
1932-33 \\
1933-34\end{array}$ & $\begin{array}{l}0 \\
0\end{array}$ & $\begin{array}{l}0 \\
0 \\
0 \\
0\end{array}$ & $\begin{array}{l}0 \\
0 \\
0\end{array}$ & $\begin{array}{l}0 \\
0 \\
0\end{array}$ & $\begin{array}{c}1.3 \\
T \\
1.1 \\
9.0\end{array}$ & $\begin{array}{l}7.4 \\
9.5 \\
1.8 \\
8.3 \\
1.9\end{array}$ & $\begin{array}{r}3.1 \\
12.9 \\
2.8 \\
5.0 \\
0.5\end{array}$ & \begin{tabular}{|c|}
6.5 \\
6.1 \\
9.4 \\
20.7 \\
31.5
\end{tabular} & $\begin{array}{l}7 \\
6.0 \\
2.3 \\
8.3 \\
9.0\end{array}$ & \begin{tabular}{c|}
$T$ \\
$T$ \\
0,1 \\
1,0 \\
0
\end{tabular} & $\begin{array}{l}0 \\
0 \\
0 \\
0 \\
0\end{array}$ & $\begin{array}{l}0 \\
0 \\
0 \\
0 \\
0\end{array}$ & $\begin{array}{l}18.3 \\
34.5 \\
17.3 \\
10.3 \\
65.8\end{array}$ \\
\hline
\end{tabular}

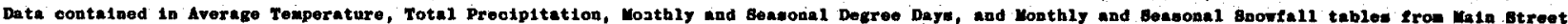

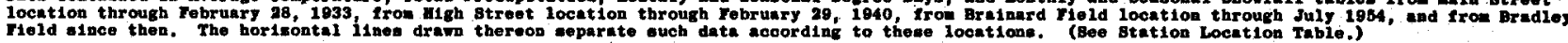

STATION LOCATION

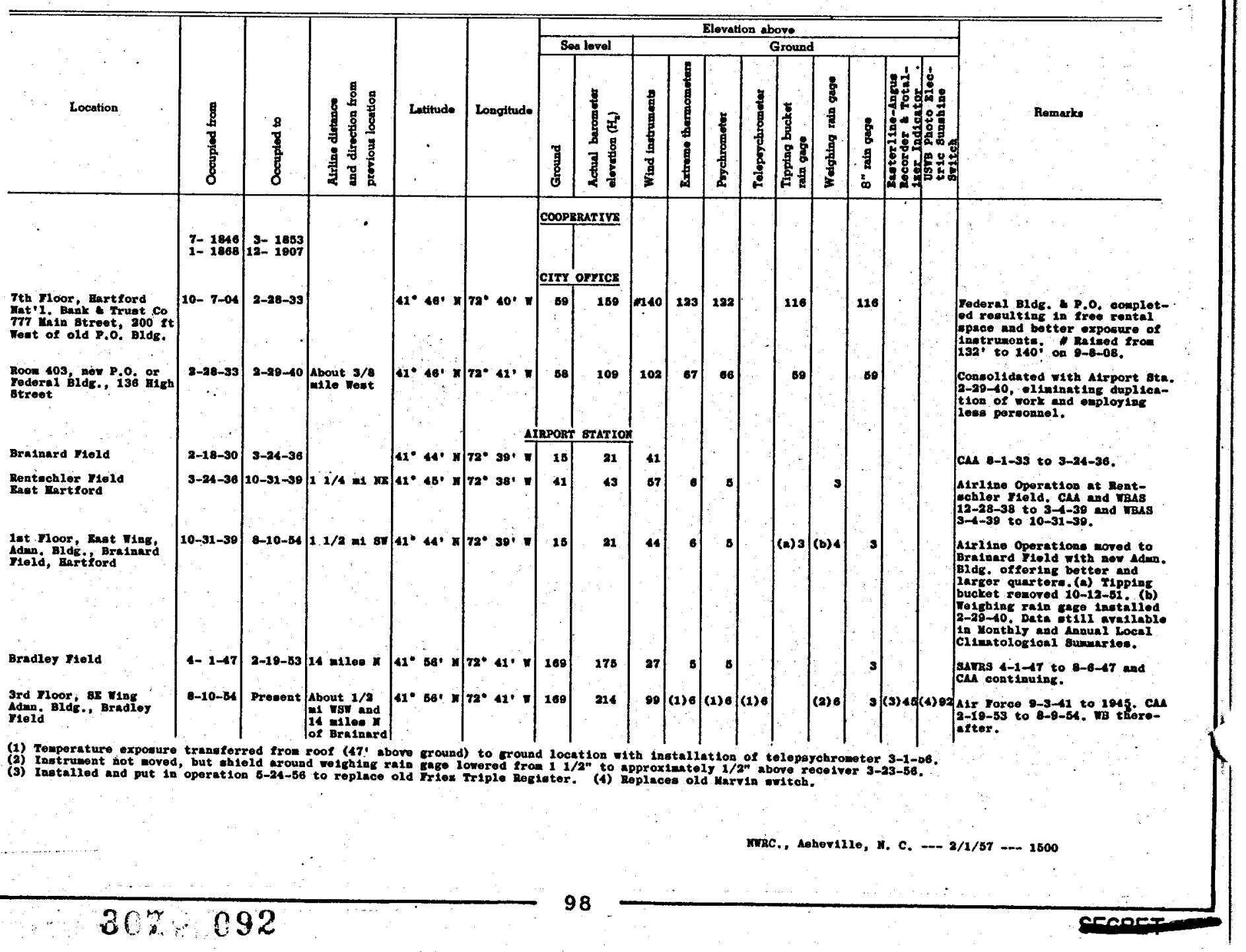




\section{AVERAGE TEMPERATURE}

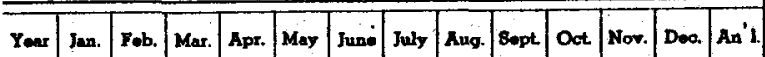

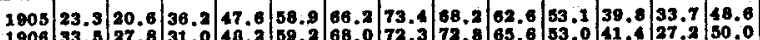

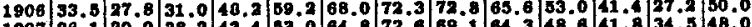

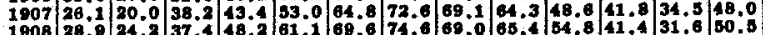
1909 28.0 32.2 35:0 46.8 67.5 68.2 70:8 68.6 62.6 51.0 64.8 28.2 49:6

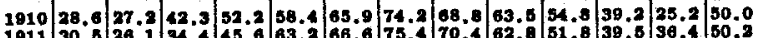

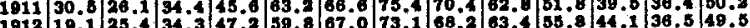

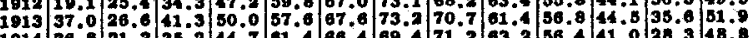

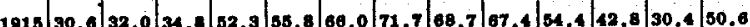

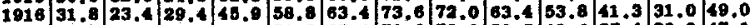

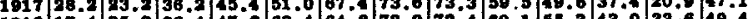

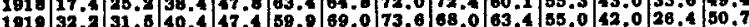

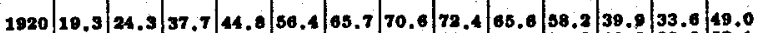
1921 30.0 31.2 45.2 53.859 .8 68.2 75.468 .208 .853 .2 30.9 30.0 32.1

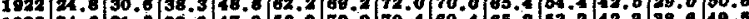

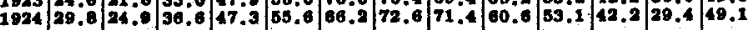

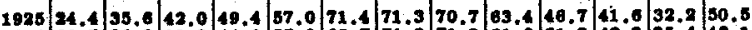

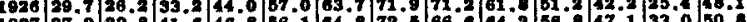

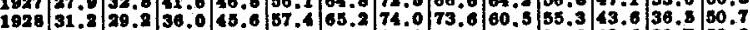

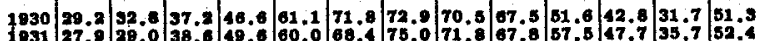

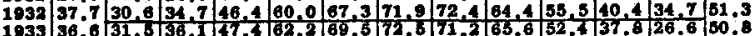

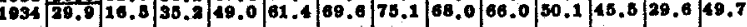

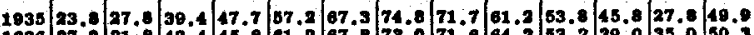
1936 27.2 21.8 43.4 5.8 101.2 67.8

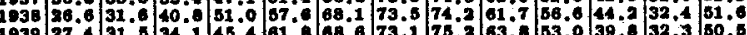

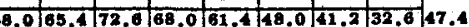

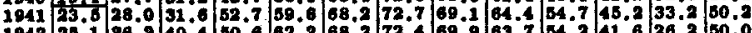

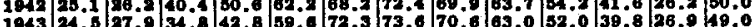

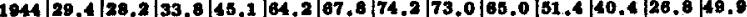

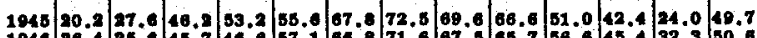

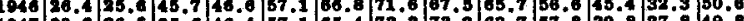

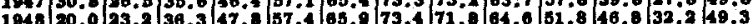

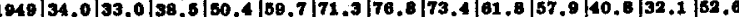

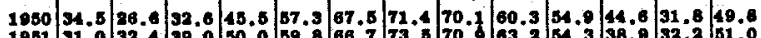

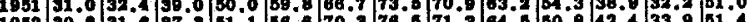

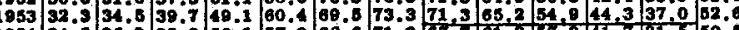

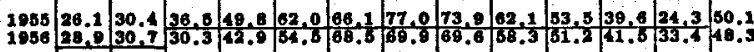
exconom

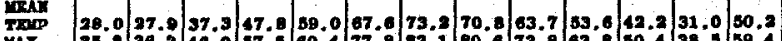

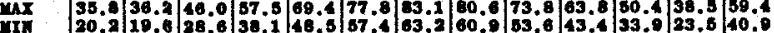

TOTAL PRECIPTTATION

MARTTORD, COHNRCTICUT BRADLEY TIETD

\begin{tabular}{|l|l|l|l|l|l|l|l|l|l|l|l|l|l|}
\hline Yoar & Jan. & Teb. & Mar. & Apr. & May & Juno & July & Aug. & Sopt. & Oct. & Norr. & Dece. & Anaual \\
\hline
\end{tabular}

\begin{tabular}{l|l|l|l|l|l|l|l|l|l|l|l|l|l}
1905 & 4.04 & 1.79 & 3.35 & 2.57 & 1.25 & 4.83 & 2.71 & 3.08 & 3.43 & 2.23 & 1.77 & 3.47 & 37.14
\end{tabular}

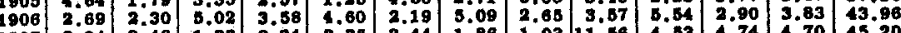

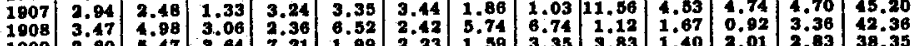

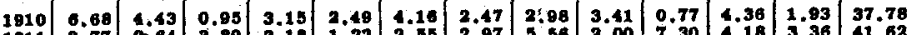

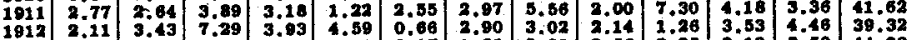

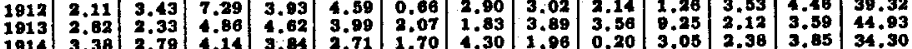
\begin{tabular}{llllllllllllllll}
1915 & 5.70 & 4.30 & 0.29 & 1.58 & 2.53 & 1.51 & 6.97 & 6.83 & 1.28 & 2.74 & 1.78 & 4.78 & 40.27 \\
\hline
\end{tabular} $\begin{array}{llllllllllllll}1916 & 1.16 & 5.72 & 2.77 & 2.93 & 3.14 & 3.86 & 3.32 & 3.44 & 3.46 & 1.08 & 2.83 & 2.99 & 36.90\end{array}$

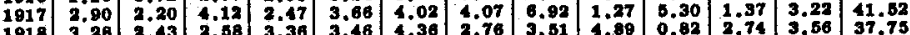

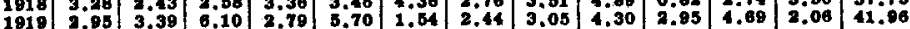
$\begin{array}{llllllllllllll}1020 & 3.39 & 6.08 & 3.75 & 5.43 & 3.53 & 8.00 & 0.70 & 3.45 & 7.05 & 0.90 & 6.43 & 6.35 & 60.98\end{array}$

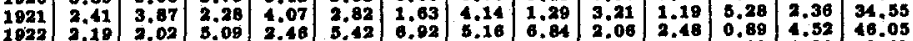

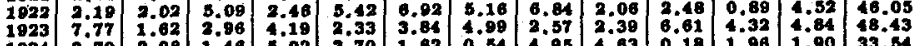
$\begin{array}{llllllllllllllll}1925 & 3.98 & 3.30 & 3.78 & 1.97 & 2.38 & 3.38 & 6.68 & 2.38 & 2.39 & 3.92 & 2.09 & 2.99 & 38.13\end{array}$

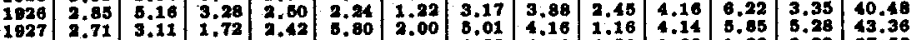

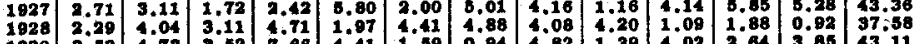
$\begin{array}{llllllllllllll}1930 & 2.01 & 2.05 & 3.04 & 1.68 & 4.57 & 4.54 & 2.55 & 1.02 & 1.31 & 2.43 & 3.51 & 3.35 & 33.06\end{array}$

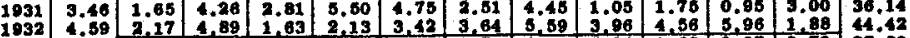

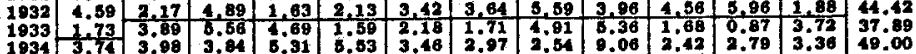
$\begin{array}{lllllllllllllll}1035 & 6.01 & 3.33 & 1.93 & 2.05 & 1.00 & 2.74 & 5.99 & 0.93 & 4.08 & 0.68 & 3.59 & 0.99 & 33.78\end{array}$

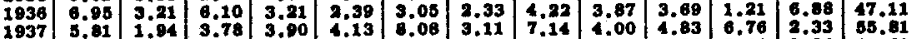

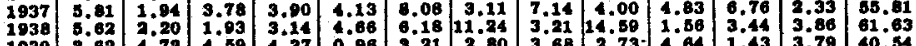
$\begin{array}{lllllllllllllll}2940 & 3.69 & 3.09 & 5.10 & 5.38 & 7.04 & 4.32 & 3.88 & 1.79 & 2.37 & 2.67 & 5.46 & 2.67 & 17.36\end{array}$

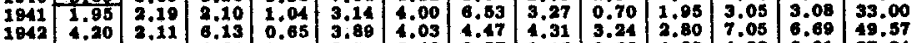

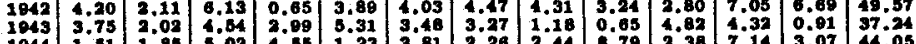

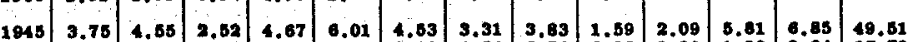

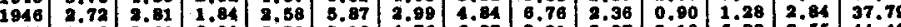

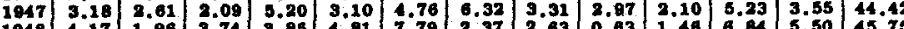

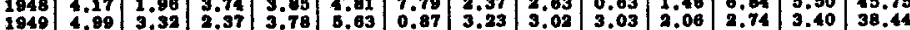

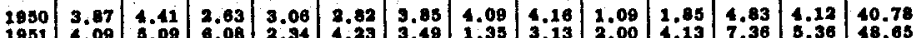

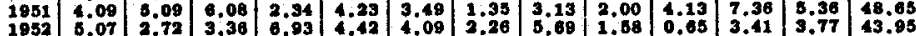

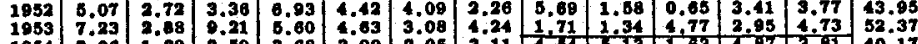

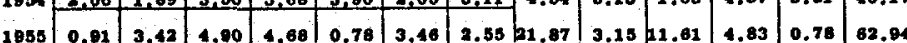

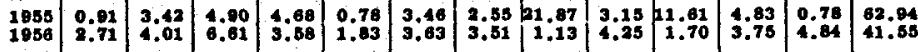

\begin{tabular}{lllllllllllllll}
\hline REAN & 3.62 & 3.21 & 3.78 & 3.04 & 3.61 & 3.60 & 3.71 & 4.07 & 3.42 & 3.01 & 3.68 & 3.58 & 42.83
\end{tabular}

\section{MONTHLY AND SEASONAL DEGREE DAYS}

\begin{tabular}{|c|c|c|c|c|c|c|c|c|c|c|c|c|c|}
\hline Seacon & dy & Ang. & Sopt. & oxt & Nor. & Des. & Jan. & Fob. & Mat. & Apr. & May & June & Total \\
\hline $\begin{array}{l}1908- \\
1006 \\
1007\end{array}$ & $\begin{array}{l}0 \\
1 \\
1 \\
0\end{array}$ & $\begin{array}{r}4 \\
1 \\
18 \\
34\end{array}$ & $\begin{array}{r}102 \\
08 \\
104 \\
04\end{array}$ & $\begin{array}{l}379 \\
376 \\
806 \\
320\end{array}$ & $\begin{array}{l}759 \\
705 \\
698 \\
710\end{array}$ & $\left|\begin{array}{r}970 \\
1173 \\
944 \\
1040\end{array}\right|$ & $\begin{array}{r}1297 \\
980 \\
1204 \\
1119 \\
1118\end{array}$ & & $\begin{array}{r}293 \\
1051 \\
833 \\
853 \\
025\end{array}$ & $\begin{array}{l}822 \\
505 \\
649 \\
815 \\
\mathbf{8 4 3}\end{array}$ & $\begin{array}{l}212 \\
237 \\
377 \\
180 \\
241\end{array}$ & $\begin{array}{r}67 \\
30 \\
119 \\
18 \\
31\end{array}$ & $\begin{array}{l}6092 \\
6770 \\
6119 \\
5961\end{array}$ \\
\hline $\begin{array}{l}1009-10 \\
1910-11 \\
1911-12 \\
1912-13 \\
1919-14\end{array}$ & $\begin{array}{l}3 \\
1 \\
4 \\
0\end{array}$ & \begin{tabular}{r|}
32 \\
7 \\
33 \\
3 \\
1
\end{tabular} & $\begin{array}{r}105 \\
92 \\
125 \\
193 \\
148\end{array}$ & $\begin{array}{l}496 \\
932 \\
410 \\
287 \\
271\end{array}$ & $\begin{array}{l}608 \\
776 \\
763 \\
629 \\
613\end{array}$ & $\begin{array}{r}1141 \\
1238 \\
887 \\
882 \\
914\end{array}$ & $\begin{array}{r}1125 \\
1088 \\
1418 \\
667 \\
1180\end{array}$ & & $\begin{array}{l}705 \\
047 \\
053 \\
732 \\
026\end{array}$ & $\begin{array}{l}381 \\
884 \\
635 \\
658 \\
612\end{array}$ & $\begin{array}{l}216 \\
129 \\
179 \\
249 \\
172\end{array}$ & $\begin{array}{l}91 \\
61 \\
64 \\
35 \\
40\end{array}$ & $\begin{array}{l}5900 \\
6300 \\
6500 \\
5380 \\
6110\end{array}$ \\
\hline $\begin{array}{l}1914-18 \\
1016-10 \\
1016-17 \\
1917-19 \\
1010-10\end{array}$ & $\begin{array}{r}23 \\
2 \\
1 \\
6\end{array}$ & \begin{tabular}{r|}
1 \\
38 \\
13 \\
0 \\
0
\end{tabular} & $\begin{array}{r}148 \\
97 \\
106 \\
176 \\
170\end{array}$ & $\begin{array}{l}870 \\
328 \\
357 \\
477 \\
305\end{array}$ & $\begin{array}{l}710 \\
664 \\
708 \\
820 \\
662\end{array}$ & $\mid \begin{array}{r}1138 \\
1074 \\
1052 \\
1367 \\
973\end{array}$ & $\begin{array}{l}1064 \\
1032 \\
1139 \\
1473 \\
1017\end{array}$ & $\left|\begin{array}{r}928 \\
1206 \\
1171 \\
1118 \\
037\end{array}\right|$ & $\begin{array}{r}939 \\
1105 \\
994 \\
821 \\
760\end{array}$ & $\begin{array}{l}990 \\
878 \\
689 \\
514 \\
629\end{array}$ & $\begin{array}{r}287 \\
203 \\
136 \\
85 \\
188\end{array}$ & $\begin{array}{l}49 \\
24 \\
24 \\
36\end{array}$ & $\begin{array}{l}8960 \\
6409 \\
6494 \\
6936 \\
8592\end{array}$ \\
\hline $\begin{array}{l}1918-20 \\
1020-21 \\
1021-29 \\
1022-23 \\
1023-21\end{array}$ & 4 & \begin{tabular}{l|}
28 \\
0 \\
10 \\
10 \\
10
\end{tabular} & $\begin{array}{l}89 \\
53 \\
28 \\
78 \\
70\end{array}$ & $\begin{array}{c}331 \\
221 \\
364 \\
338 \\
386\end{array}$ & $\begin{array}{l}691 \\
753 \\
720 \\
673 \\
685\end{array}$ & $\begin{array}{l}1196 \\
979 \\
1024 \\
1113 \\
010\end{array}$ & $\begin{array}{l}1415 \\
1085 \\
1243 \\
1257 \\
1088\end{array}$ & $\left|\begin{array}{r}1182 \\
048 \\
965 \\
1208 \\
1163\end{array}\right|$ & $\begin{array}{l}843 \\
615 \\
830 \\
689 \\
877\end{array}$ & $\begin{array}{l}605 \\
360 \\
491 \\
621 \\
834\end{array}$ & $\begin{array}{l}274 \\
199 \\
120 \\
227 \\
289\end{array}$ & $\begin{array}{l}83 \\
28 \\
11 \\
27 \\
07\end{array}$ & $\begin{array}{l}6748 \\
8235 \\
8872 \\
6468 \\
3977\end{array}$ \\
\hline $\begin{array}{l}1924-20 \\
1925-20 \\
1026-27 \\
1927-28 \\
1028-20\end{array}$ & $\begin{array}{l}0 \\
1 \\
8 \\
8 \\
0\end{array}$ & \begin{tabular}{r|}
5 \\
23 \\
12 \\
34 \\
2
\end{tabular} & $\begin{array}{r}169 \\
125 \\
119 \\
69 \\
161\end{array}$ & $\begin{array}{l}375 \\
565 \\
136 \\
295 \\
328\end{array}$ & $\begin{array}{l}681 \\
701 \\
687 \\
639 \\
641\end{array}$ & $\begin{array}{c}1098 \\
1018 \\
1227 \\
992 \\
882\end{array}$ & $\begin{array}{l}1255 \\
1095 \\
1135 \\
1045 \\
1174\end{array}$ & $\left|\begin{array}{r}828 \\
1087 \\
902 \\
2012 \\
986\end{array}\right|$ & $\begin{array}{l}713 \\
093 \\
727 \\
003 \\
723\end{array}$ & $\begin{array}{l}\mathbf{6 1} \\
628 \\
549 \\
693 \\
820\end{array}$ & $\begin{array}{l}250 \\
251 \\
\mathbf{2 7 7} \\
\mathbf{2 3 8} \\
221\end{array}$ & $\begin{array}{l}14 \\
6 \\
6 \\
62 \\
62\end{array}$ & $\begin{array}{l}6573 \\
6165 \\
8811 \\
5602\end{array}$ \\
\hline $\begin{array}{l}1929-30 \\
1930-31 \\
1931-32 \\
1032-33 \\
1033-34\end{array}$ & 7 & $\begin{array}{l}12 \\
13 \\
4\end{array}$ & $\begin{array}{r}00 \\
42 \\
85 \\
101 \\
101\end{array}$ & $\begin{array}{l}416 \\
416 \\
280 \\
304 \\
380\end{array}$ & $\begin{array}{l}677 \\
669 \\
520 \\
741\end{array}$ & \begin{tabular}{|c|}
1064 \\
1035 \\
911 \\
940 \\
1195 \\
\end{tabular} & $\begin{array}{r}1110 \\
1149 \\
049 \\
079 \\
1091\end{array}$ & $\begin{array}{r}900 \\
1010 \\
096 \\
1339 \\
1358\end{array}$ & $\begin{array}{l}862 \\
817 \\
938 \\
895 \\
922\end{array}$ & $\begin{array}{l}548 \\
463 \\
558 \\
524 \\
482\end{array}$ & $\begin{array}{l}180 \\
205 \\
190 \\
129 \\
157\end{array}$ & $\begin{array}{r}8 \\
28 \\
83 \\
50 \\
36\end{array}$ & $\begin{array}{l}8883 \\
8841 \\
8324 \\
8502 \\
6520\end{array}$ \\
\hline
\end{tabular}

\begin{tabular}{|c|c|c|c|c|c|c|c|c|c|c|c|c|c|}
\hline Soscon & Suly & Aug. & Sopt. & Oot. & Nov. & Des. & Jan. & Fob. & Mar. & Apr. & May & juan & Total \\
\hline $\begin{array}{l}1034-38 \\
1935-38 \\
1936-37 \\
1937-38 \\
1938-30\end{array}$ & & 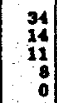 & $\begin{array}{l}138 \\
100 \\
154 \\
126\end{array}$ & $\begin{array}{l}480 \\
348 \\
371 \\
423 \\
272\end{array}$ & $\begin{array}{l}573 \\
784 \\
686 \\
629\end{array}$ & $\mid \begin{array}{l}1007 \\
1151 \\
929 \\
1050 \\
1013\end{array}$ & $\begin{array}{l}1275 \\
1168 \\
905 \\
1189 \\
1165\end{array}$ & $\begin{array}{r}1043 \\
1253 \\
897 \\
938 \\
942\end{array}$ & $\begin{array}{l}793 \\
686 \\
980 \\
748 \\
988\end{array}$ & $\begin{array}{l}825 \\
881 \\
538 \\
138 \\
686\end{array}$ & $\begin{array}{l}289 \\
158 \\
114 \\
237 \\
174\end{array}$ & $\begin{array}{l}15 \\
18 \\
28 \\
18\end{array}$ & $\begin{array}{l}6168 \\
6051 \\
8683 \\
8878 \\
8888\end{array}$ \\
\hline $\begin{array}{l}1939-40 \\
1990-41 \\
1941-42 \\
1994-43 \\
1943-14\end{array}$ & & 2 & $\begin{array}{l}96 \\
1190 \\
1104 \\
110 \\
129\end{array}$ & $\begin{array}{l}387 \\
525 \\
343 \\
333 \\
405\end{array}$ & $\begin{array}{l}780 \\
7712 \\
780 \\
703 \\
750\end{array}$ & $\begin{array}{l}1012 \\
1006 \\
986 \\
2000 \\
1183\end{array}$ & $\begin{array}{l}1416 \\
12182 \\
1237 \\
12358 \\
1106\end{array}$ & $\begin{array}{l}1080 \\
1038 \\
1093 \\
1037 \\
1084\end{array}$ & $\begin{array}{c}1044 \\
1033 \\
761 \\
935 \\
962\end{array}$ & \begin{tabular}{|l}
638 \\
3770 \\
433 \\
665 \\
698
\end{tabular} & \begin{tabular}{|l|}
221 \\
199 \\
120 \\
194 \\
88
\end{tabular} & $\begin{array}{l}77 \\
75 \\
34 \\
22 \\
14\end{array}$ & $\begin{array}{l}6733 \\
8825 \\
5732 \\
6477 \\
6343\end{array}$ \\
\hline 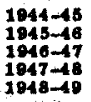 & & $\begin{array}{l}21 \\
34 \\
29\end{array}$ & $\begin{array}{r}77 \\
77 \\
188 \\
08 \\
08\end{array}$ & $\begin{array}{l}430 \\
132 \\
278 \\
238 \\
414\end{array}$ & $\begin{array}{l}741 \\
678 \\
687 \\
758 \\
667\end{array}$ & $\begin{array}{l}1186 \\
11270 \\
1013 \\
1154 \\
1010\end{array}$ & $\mid$\begin{tabular}{|c|c|}
1390 \\
1196 \\
1003 \\
1396 \\
963 \\
963
\end{tabular} & \begin{tabular}{|l|l|}
1042 \\
1104 \\
1077 \\
1121 \\
897
\end{tabular} & $\begin{array}{l}889 \\
589 \\
809 \\
890 \\
825\end{array}$ & $\begin{array}{l}357 \\
349 \\
557 \\
515 \\
145\end{array}$ & $\begin{array}{l}293 \\
2262 \\
273 \\
234 \\
193\end{array}$ & $\begin{array}{l}88 \\
74 \\
72 \\
57 \\
20\end{array}$ & $\begin{array}{l}6231 \\
68270 \\
5911 \\
6635 \\
6420\end{array}$ \\
\hline $\begin{array}{l}1949-1 \\
1950-1 \\
1951-1 \\
1952- \\
1953-1\end{array}$ & & 8 & $\begin{array}{r}132 \\
183 \\
101 \\
73 \\
99 \\
90\end{array}$ & $\begin{array}{r}257 \\
315 \\
331 \\
132 \\
309 \\
\end{array}$ & $\begin{array}{l}728 \\
607 \\
775 \\
6771 \\
6 \div 9\end{array}$ & \begin{tabular}{|c|c|c|}
1020 \\
1024 \\
1005 \\
955 \\
862 \\
862
\end{tabular} & $\begin{array}{l}2039 \\
2046 \\
2043 \\
1009 \\
1251 \\
1251\end{array}$ & $\begin{array}{l}1088 \\
908 \\
980 \\
850 \\
803 \\
803\end{array}$ & $\begin{array}{l}988 \\
801 \\
854 \\
776 \\
702 \\
802\end{array}$ & $\begin{array}{l}373 \\
411 \\
112 \\
187 \\
118 \\
118\end{array}$ & $\begin{array}{l}236 \\
279 \\
258 \\
164 \\
231 \\
\end{array}$ & $\begin{array}{l}18 \\
54 \\
34 \\
21\end{array}$ & \\
\hline $\begin{array}{l}54-5 \\
55-5 \\
58-5\end{array}$ & & & 40 & 300 & & & $\begin{array}{l}198 \\
113\end{array}$ & $\begin{array}{r}961 \\
986 \\
\end{array}$ & & $\frac{419}{853}$ & $\frac{129}{340}$ & $\frac{69}{37}$ & \\
\hline
\end{tabular}




\section{Visibility}

Weather and Obstructions to Visibility

The parameters listed above are recorded on IBM punch cards and fed into the IBM-704 for tabulation and summation by months, seasons, and years.

The following summaries are tabulated and printed by the IBM machines on a monthly, seasonal, and annual basis:

Frequency of Sky Cover Classes by hours of the day.

Frequency of Visibility Classes by hours of the day.

Hourly Occurrences of Precipitation amounts.

200 feet Wind Direction during hours of precipitation.

Average temperatures by hours of the day.

Wet Bulb frequencies.

Average Wet Bulb temperatures by hours of the day.

Frequency of temperature gradients by hours of the day:

5 to 50 feet :

5 to 150 feet

5 to 200 feet

Frequency of persistence of Inversions:

5 to 50 feet

5 to 150 feet

5 to 200 feet

Frequency of persistence of lapse conditions:

5 to 50 feet

5 to 150 feet

5 to 200 feet

Average Wind Speed by hours of the day:

15-foot level

200-foot level

Correlation of 200-foot Wind Direction with Temperature Gradient:

5 to 50 feet

5 to 150 feet

5 to 200 feet

Frequency of Wind Direction by speed, for each hour of the day:

15-foot level

200-foot level

Frequency of Wind Direction by speed, for all hours:

15-foot level

200-foot level

Correlation of 15-foot Wind Direction with 200-foot Wind Direction. 
Frequency of Wind Persistence:

15-foot level

200-foot level

Average Wind Speed by stability (unstable, neutral, stable):

15-foot level

5 to 50 feet

5 to 150 feet

5 to 200 feet

200-foot level

5 to 50 feet

5 to 150 feet

5 to 200 feet

In addition, portable wind measuring and recording units are moved about to various locations on the site. The first portable unit was put into operation in late December, 1956. A smoke study program and balloon run program are also underway.

\section{Climatological Review of Hartford Area}

In the present brief report, the meteorological parameters which directly influence the diffusion of material by the atmosphere will be stressed.

\section{a. Surface Wind Direction}

The hourly observations for a five-year period, 1934 to 1938 , for the Weather Bureau Airport Station at Hartford (Brainard and Rentschler Fields) were studied in detail. Fig 26 presents the percentage frequency of the wind direction. The term "prevailing direction" does not strictly apply to this location since the wind directions are almost equally divided into winds from the northerly quadrant (90 degree arc from northwest through north-northeast) and from the southerly quadrant (90 degree arc from south-southeast through southwest). There is, however, a definite seasonal shift with almost half the winter time winds blowing down-valley from a northerly direction, while in summer 45 percent of the wind directions are southerly. In spring and fall there is an almost equal frequency of both northerly and southerly winds. The channeling of winds is particularly evident in the very low frequency of east winds. On the average, winds from the easterly quadrant occur less than 10 percent of the time.

It is necessary to examine the wind structure during periods of precipitation in order to consider the effect of washout of material from the atmosphere. Fig 26 also presents the frequency of wind directions at Hartford during those hours when precipitation was falling. (This was approximately 12 percent of the time). Except for the summer months, the prevailing rain wind is north and north-northeast. During summer, and associated with showers or thunderstorms, the most frequent rain wind will be southerly. Wind direction may also be important when the atmosphere is very stable and diffusion is a minimum. Data correlating temperature gradient and wind direction are limited and inconclusive at this time, but it seems likely that light north or south winds will occur with the usual nocturnal nonpersistant inversion. For persistent (i.e., more than one day) inversions, the wind direction is likely to be east or southeast. 
Percentage Frequency of Wind Direction, Weather Bureau Airport Station, Hartford, Connecticut (Based on hourly observations 1934 through 1938)

Wintér Spring Summer Fall Annual Summer (1949-1954) Annual (duration precipitation)

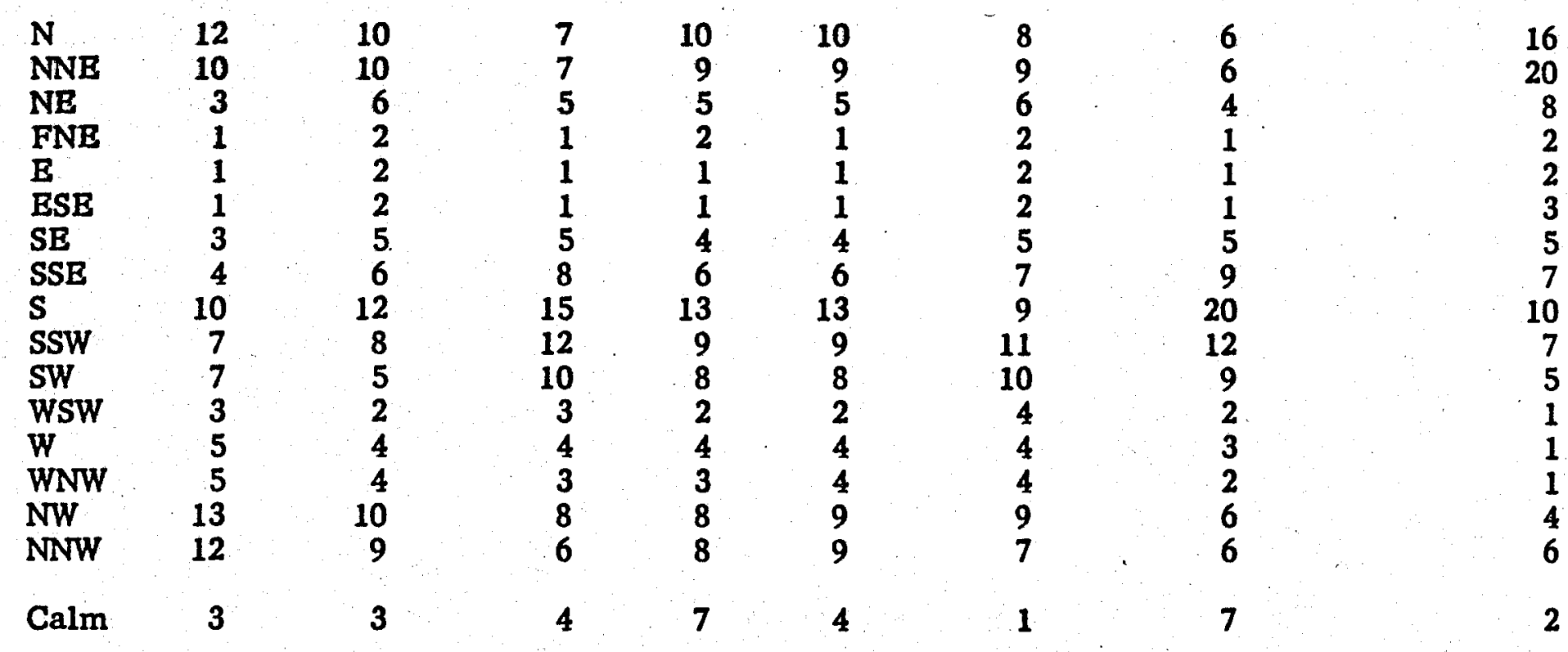

*Day 8 a.m.-5 p.m. Night 5 p.m. -7 a.m. 


\section{b. Surface Wind Speed}

Fig 27 presents the percentage frequency of wind speeds in various class intervals. The distribution of speeds is constant with the season. Over $\mathbf{5 0}$ percent of the wind speeds will be in the 4 to $12 \mathrm{mph}$ category. Also of note is the high percentage of low wind speeds (less than $4 \mathrm{mph}$ ). In the summer more than 30 percent of the wind speeds are in this category, decreasing to 19 percent in the spring. Spring is also the season of the strongest average winds with a mean speed of $9.4 \mathrm{mph}$ compared to the summer low of $7.0 \mathrm{mph}$. During a 38-year period of record, wind speeds have reached $50 \mathrm{mph}$ or higher in all but 4 months of the year. The highest recorded one-minute wind speed at Hartford occurred in November, 1950, with a wind of $70 \mathrm{mph}$. However, winds of higher speeds, approaching $100 \mathrm{mph}$, are not improbable.

Two localized types of storms, tornadoes and thunderstorms, which may be accompanied by high winds deserve special mention. Tornadoes are rare in Connecticut with only 9 . reported during 35 years from 1916 through 1950 .

Thunderstorms are fairly common but are mostly a summer phenomena occurring with maximum frequency in July, when an average of 7 per month can be expected. Thunderstorm winds are extremely variable but a rare severe storm may cause short duration winds in excess of $50 \mathrm{mph}$, one-inch or more of rain in an hour, and hailstones $1 / 2$-inch or larger in diameter.

\section{c. Precipitation}

As shown in the attached Local Climatological Data, the Hartford area receives approximately 40 inches of precipitation annually which will be spread over an average of 127 days. Precipitation is distributed rather evenly throughout the year with the maximum during the spring and summer. The recent hurricane Diane (August, 1955) established record short-period rainfall amounts and at Hartford caused amounts greater than had previously been recorded during more than 50 years of record. This storm resulted in 12.05 inches of rain in 24 hours at Hartford and the total for the two-day storm was 13.97 inches. The snowfall in this area averages about 40 inches per year, with one-inch or more of snow occurring on approximately 10 days per year. The largest snowfall recorded in 24 hours was 19 inches, and for one month 45.3 inches.

\section{d. Atmosphere Stability}

Prior to the commencement of the extensive data collection program at the proposed site in April, 1956, measurements of vertical temperature gradient distribution had not been made in the Hartford area. However, measurements made at other locations show that low-level inversions are characteristic of the night hours and there is a high correlation between low wind periods, restricted visibility and the occurrence of inversions. Conversely, high wind speeds and good visibility are indicative of "lapse" conditions and rapid diffusion by the atmosphere. The Hartford area experiences approximately 45 days per year when heavy fog occurs. Visibility is reduced to 6 miles or below approximately 30 percent of the time, on an annual basis.

Obviously not every occurrence of a stable lapse rate will be accompanied by lowered visibility. Although inversions form often at night, there is nothing in the records that could be interpreted to signify that Hartford experiences an unusual amount of stable atmospheric conditions . 
Percentage Frequency of Wind Speed Groups (mph), Weather Bureau Airport Station, Hartford, Connecticut (Based on hourly observations 1934 through 1938)

\begin{tabular}{|c|c|c|c|c|c|c|}
\hline $\begin{array}{l}\text { Wind } \\
\text { Speed } \\
\text { Group }\end{array}$ & Winter & Spring & Summer & Fall & $\begin{array}{c}\text { Annual } \\
\text { (All obs.) }\end{array}$ & $\begin{array}{l}\text { Annual (during precipitation) } \\
\qquad(1949-1954)\end{array}$ \\
\hline $\begin{array}{l}\text { Calm } \\
1-3 \mathrm{mph}\end{array}$ & $3 \%$ & $\begin{array}{l}3 \% \\
16\end{array}$ & 27 & $23 \%$ & $215 \%$ & $2 \%$ \\
\hline $4-7$ & 24 & 24 & 31 & 26 & 26 & \\
\hline $8-12$ & 29 & 29 & 26 & 27 & 27 & 61 \\
\hline $13-18$ & 19 & 21 & 11 & 15 & 16 & \\
\hline $\begin{array}{l}19-24 \\
25-31 \\
32-46 \\
46\end{array}$ & $\begin{array}{l}6 \\
1 \\
*\end{array}$ & $\begin{array}{l}6 \\
1 \\
* \\
*\end{array}$ & $\begin{array}{l}1 \\
* \\
* \\
*\end{array}$ & $\begin{array}{l}2 \\
* \\
* \\
*\end{array}$ & $\begin{array}{l}4 \\
1 \\
* \\
*\end{array}$ & $\begin{array}{l}19 \\
1 \\
* \\
*\end{array}$ \\
\hline $\begin{array}{l}\text { Mean Wind } \\
\text { Speed (mph) }\end{array}$ & 9.2 & 9.4 & 7.0 & 7.5 & 8.3 & \\
\hline
\end{tabular}


4. Estimated Meteorological Differences Between Hartford and the CANEL Site

Meteorological conditions at the CANEL site will differ somewhat in two categories, wind flow and diurnal distribution of stability.

The narrower valley at the site and the protective surrounding terrain should result in lower average wind speeds. Existing site data already are indicative of this, as can be noted on Fig 28 which shows the percentage of calms at the 15-foot level for a period of a year to be 24.1 percent.

The percentage of calms at the 200-foot level is considerably less than at 15 feet as can be seen on Fig 29 . Fig 30 shows the average diurnal wind speed variations.

The channeling effect noted at Hartford should be even more pronounced at the site, with a large predominance of northeast and southerly winds. This is clearly indicated by the comparative wind roses for Hartford and CANEL (Fig 28). The wind flow axis over the site seems to be along a line from the northwest north-northwest sector to the south-southeast south sector. However, at night, during periods of light winds, the terrain will probably cause westerly drainage winds downslope from the surrounding hills and into the river valley. Evidence of this has already been recorded. These air movements will be more in the nature of drift and should rarely exceed 2 or 3 miles per hour.

It is possible that the sea breeze from Long Island Sound may reach the site. However, it seems evident that such occasions will be infrequent, and on those occasions the site would be affected for only short intervals of time.

Another effect of the surrounding terrain will be to shield the site plateau from early morning and, particularly, late afternoon solar radiation. This will probably result in earlier formation and slightly later dissipation of the nocturnal inversion than would be experienced on a level plain in the same location. Fig 31 shows the average time of start and breakup of inversions during the months of May and June, 1956, at the site.

A third difference will result from the proximity of the Connecticut River. In summer and early fall the cooler water of the river will favor early inversion formation and frequent fogs which may well deepen to encompass the site plateau. In the winter and spring the relatively warm water will lift the inversion base, from the ground, to 50 or 100 feet above the water and will favor earlier breakup of nocturnal inversion.

All of the preceding qualitative statements concern relatively minor fluctuations on the more general pattern determined from the long-period Hartford records and these fluctuations will affect primarily the site itself and seldom extend their influence more than a few miles. 


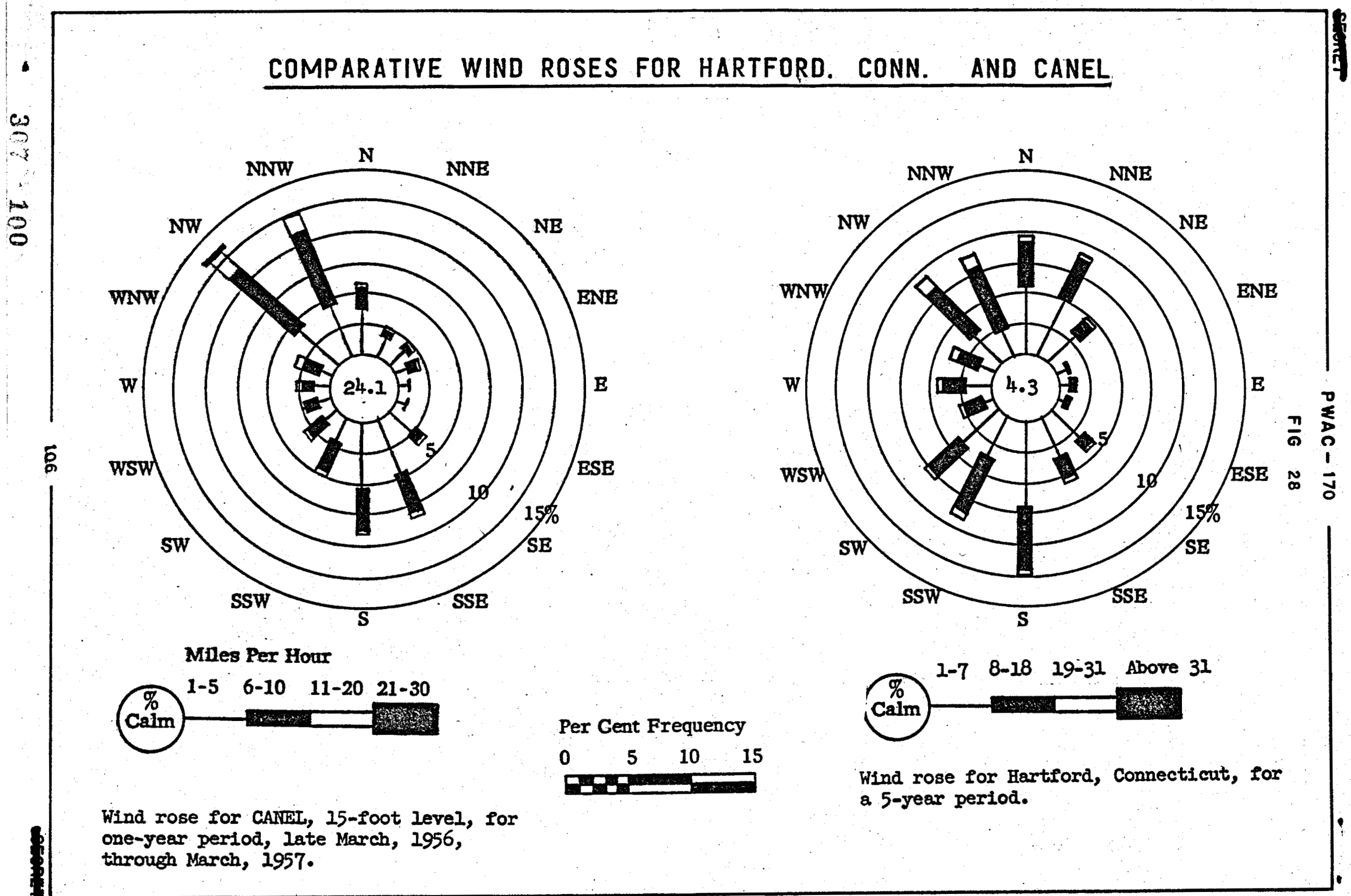


PWAC - 170

FIG 29

WIND ROSE FOR CANEL 200-FOOT LEVEL FOR ONE-YEAR PERIOD LATE MARCH. 1956. THROUGH MARCH. 1957
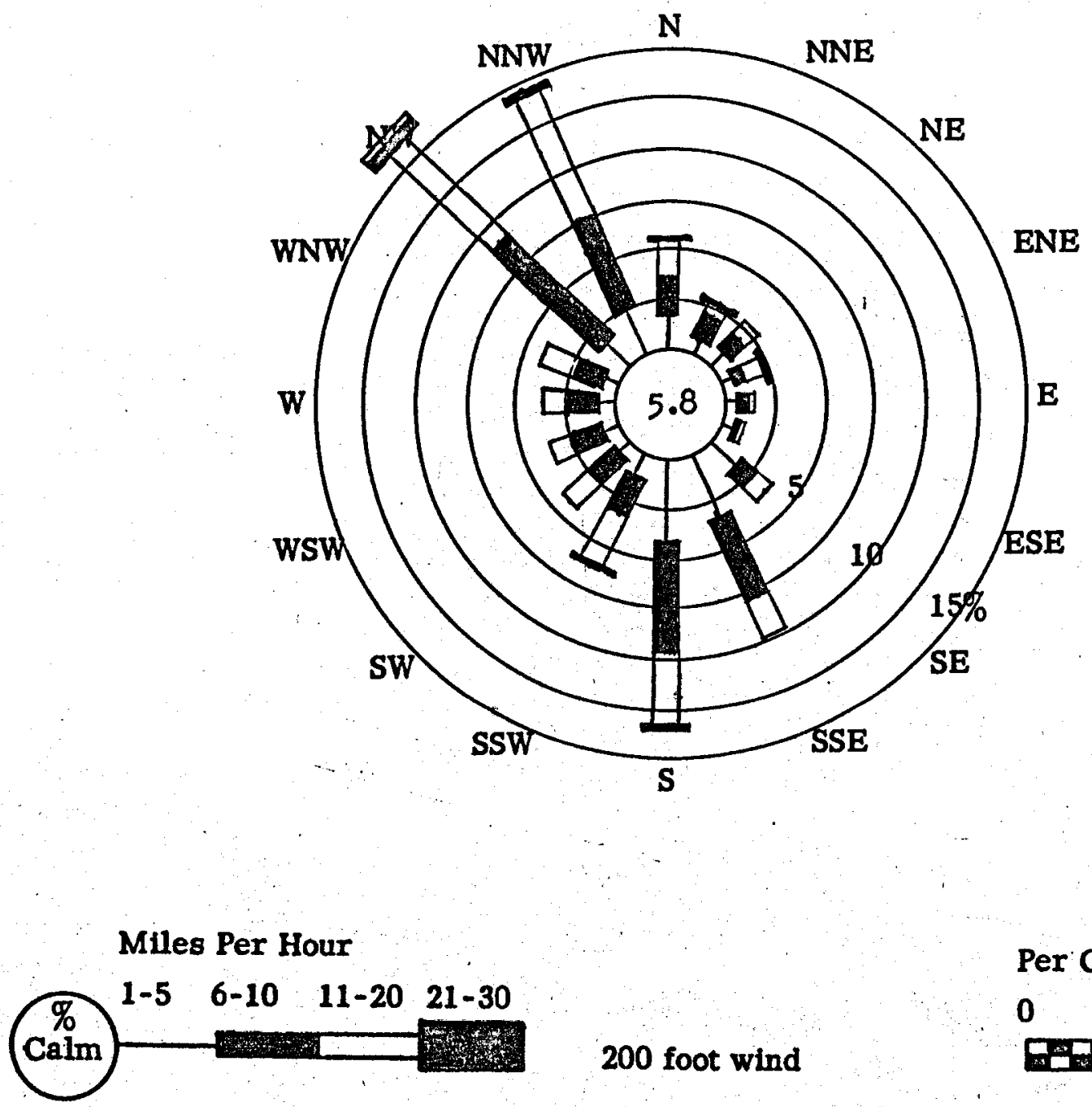

Per Cent Frequency

$\begin{array}{llll}0 & 5 & 10 & 15\end{array}$

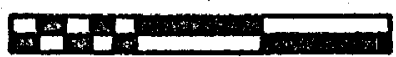


PWAC - 170

FIG 30

\section{AVERAGE DIURNAL WIND SPEED VARIATIONS AT CANEL}

\section{LATE MARCH. 1956. THROUGH MARCH. 1957}

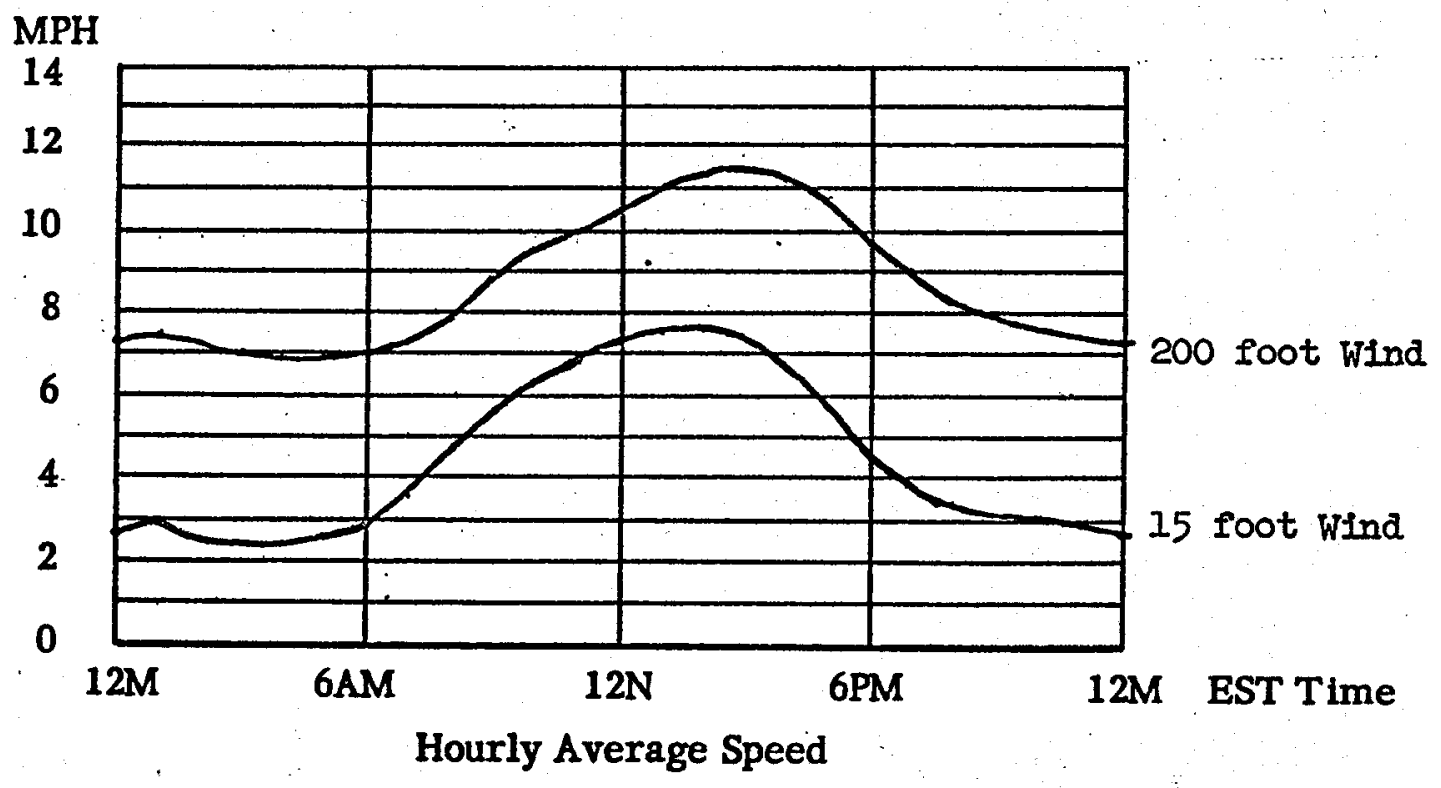




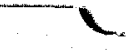

${ }^{\circ} \mathrm{F}$

3.0

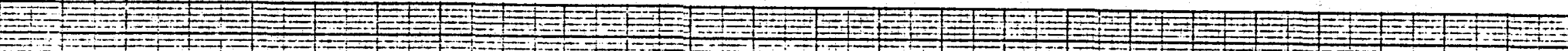

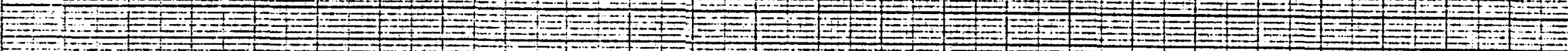

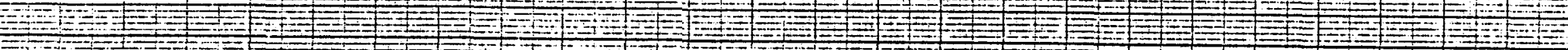

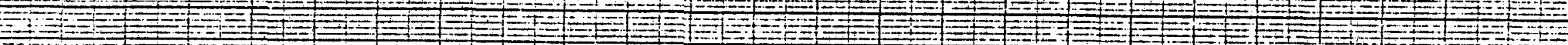

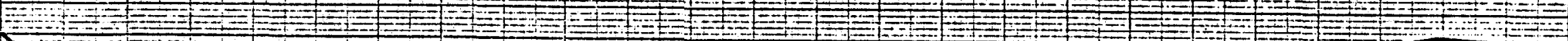

2.0

OHa

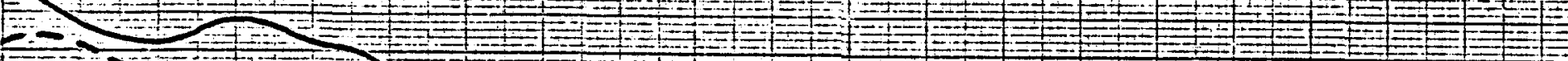

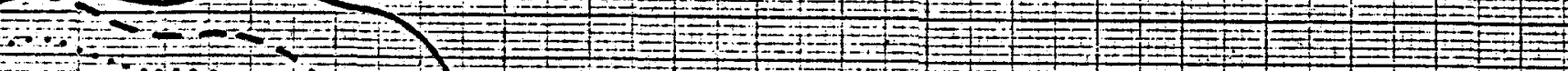

1.0

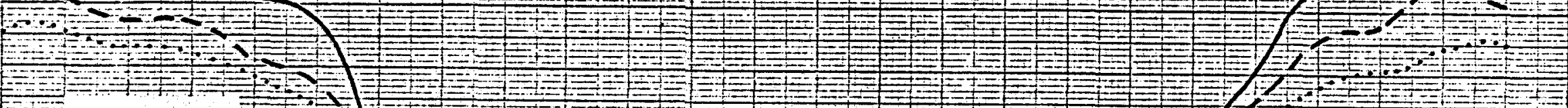

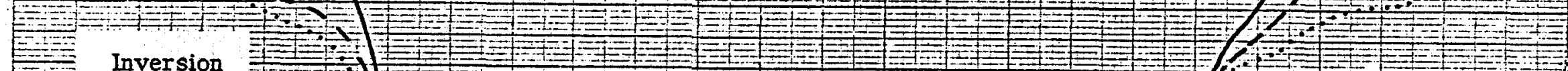

$\overrightarrow{8}$

0.0

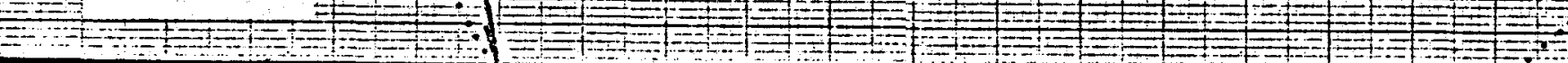

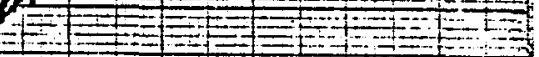

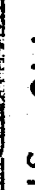

$\frac{n}{2}$

$\frac{1}{3}$

$\stackrel{\omega}{\overrightarrow{0}}$

Lapse 1

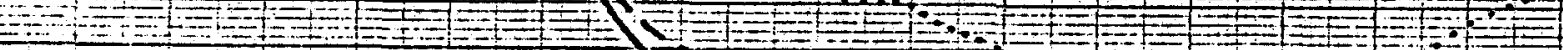

$-1.0$

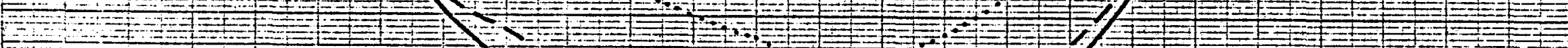

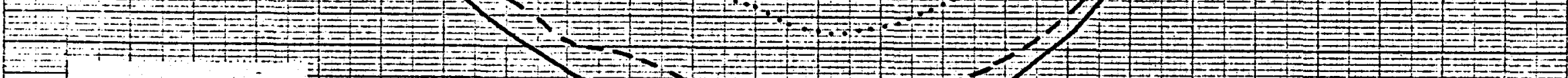

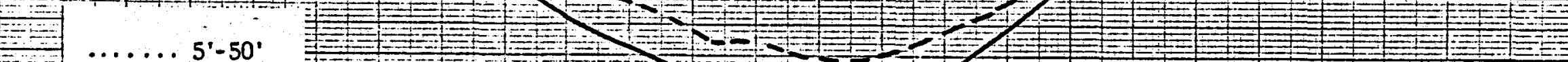
$--5^{\prime}-150^{\prime}$

$=+2=-1=$

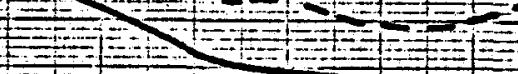
$+1$

$5^{\prime}-200$

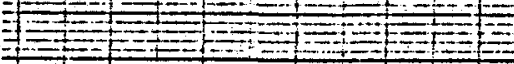

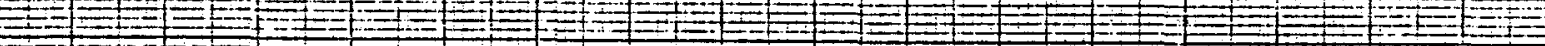
$-3.0$ 㭴

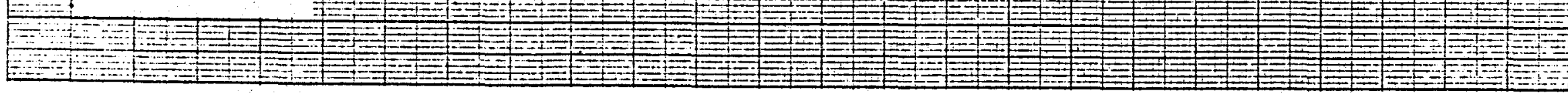

00

01

0203

$04 \quad 05$

$05 \quad 06$

$07 \cdot 08$

$09 \quad 10$

$11 \quad 12$ 


\section{E. GEOLOGY AND HYDROLOGY}

\section{Introduction}

Information following was obtained from a report based on a preliminary investigation of the geology and hydrology of the CANEL site for the Atomic Energy Commission. The report, by E. S. Simpson, was prepared by the U.S. Department of the Interior, Geological Survey. Although the conclusions offered are believed to be essentially correct, they are subject to revision as more data becomes available.

2. Topography and Drainage

The government reservation is on the right (west) bank of the Connecticut River at Middletown, Connecticut, in the Middle Haddam topographic quadrangle. The reservation occupies roughly one square mile of land area, and is bounded both on north and east by the Connecticut River which makes a right-angle bend at this place. See Fig 17.

Topographically (and geologically) the reservation may be divided into two halves. The western half which is hilly and underlain by bedrock and glacial till, reaches a maximum elevation of about $\mathbf{3 5 0}$ feet. The eastern half, on which the proposed structures will be built, is a relatively flat-topped deposit of silt and sand and minor fine gravel, most of whose surface is at an elevation of 120 to 140 feet. For convenience, this deposit will be referred to as the terrace. It is bounded on north and east by the Connecticut River, and its surface contact with the underlying bedrock is marked very nearly by the existing north-south road that traverses the reservation.

The terrace has a steep outer slope facing the river. It is dissected by two large gullies, one near the north end and one near the south end, and also by two smaller gullies located near its center. Extending along the base of the terrace is a widened part of the flood-plain of the Connecticut River and is underlain by river alluvium. It is about 3 miles long, including portions beyond the reservation. Its upstream half is a (usually) dry meadow having an average width of about 500 feet, while the downstream half is in large part a tidal flat whose maximum width is about 1500 feet. The two parts are separated by a bit of terrace that abuts the river's edge.

The Connecticut River is the master stream of the area, and all drainage from the reservation flows into it. The river in this reach is tidal and for the purposes of this report may be considered to be at sea-level elevation. On the reservation there is only one perennial stream and even it has been known to show no discharge in its upper reaches after a prolonged dry spell. Although it is unnamed on the topographic map, it will herein be called Maromas Brook. It rises in the hills, flows easterly toward the terrace, makes a loop convex southward following what appears to be the contact between the terrace and bedrock, then rapidly descends along the north gully to near river level, crosses the flood-plain where it forms sluggish pools, and thence flows into the Connecticut River. Maromas Brook has a small tributary that joins it on terrace level and which drains a pond occupying an abandoned rock quarry (hereinafter called Quarry Pond). The total drainage area of brook and tributary is about 1 square mile. There is no open body of water restricted to the terrace, probably because of the permeable nature of this deposit.

\section{$300^{y} \quad 104$}




\section{Geology}

The geologic description that follows is based on a cursory field inspection, and studies of the literature given in the references and of the available drillers' logs. It is intended that further field study of the formations will be made and that a detailed geologic map of the area will be prepared; existing published maps are small-scale and generalized.

\section{a. Bedrock}

The bedrock underlying all of the reservation consists of a series of metamorphosed (recrystallized) sedimentary rocks of Precambrian Age. They crop out in the hilly area of the western half and slope down steeply, but irregularly, under the terrace material. The stratigraphy of the rocks is complex and no attempt will be made to describe the several formations. It is believed sufficient to note that although the lithologic make-up changes from formation to formation, the waterbearing characteristics of all are roughly similar. The rock material as such is nearly impermeable, but ground water is stored and transmitted through interconnecting systems of open joints and cracks. Such water-bearing openings are known to exist down to approximately 500 feet below land surface. Beyond that depth the weight of the over-lying material is belleved to be great enough to prevent cracks from opening even though they may exist. In fact, the usual practical limit to the depth of water wells in this kind of rock is about 300 feet.

\section{b. Unconsolidated Deposits (Overburden)}

The overburden at the reservation is of three types: (1) glacial till which is a mixture of rock particles of all sizes from clay to boulders, and which was deposited directly by glacial ice, (2) glaciofluvial material derived from the ice and from exposed upland areas, but which was transported by running water, (3) river alluvium deposited by the Connecticut River in recent times.

\section{(1) Till}

The till at the reservation is deposited directly on the underlying bedrock and the contact between the two ordinarily is fresh and sharp. The clay content of the till has not yet been determined, but drillers' $\operatorname{logs}$ show it to be dense and probably only slightly permeable to the flow of ground water. It crops out in the western half of the reservation where it is found mantling almost all the bedrock. Its thickness possibly is on the order of 10 or 20 feet. However, thickness varies greatly from place to place, and cannot be predicted in advance of drilling or geophysical exploration. Where glaciofluvial material crops out at the surface, till is presumed to exist beneath it unless drilling or other data show the till to be missing.

\section{(2) Glaciofluvial Deposits}

The bulk of the material on which the proposed structures will be bullt consists of stream-carried fine-to-coarse sand with minor quantities of silt and of fine gravel, all of which were deposited in a small temporary lake (or lakes) existing during the last stages of glacial decay. The upper surface of the deposit is relatively flat and is at an elevation of 120 to 140 feet above sea-level. Its lower limit is not known but probably extends for some tens 
of feet below river grade. Thus, maximum thickness probably is on the order of 200 feet. Part of the bluff on the opposite side of the river appears to consist of the same material and may be connected to that on the government reservation via under-river deposits. The material appears to be thickest near the river's edge and thins rapidly toward its western boundary, where it is replaced by till and bedrock as the surface deposit. Between the rock and the glaciofluvial material there probably exists a fairly continuous layer of dense till. Most of the holes so far drilled into the terrace are too shallow to penetrate the till; in the few instances where till was penetrated it was found to be 8 or 10 feet thick. However, there appears to be a possibility that till underlying the glaciofluvial material near the north end of the terrace may be much thicker than 10 feet.

\section{(3) River Alluvium}

The Connecticut River in recent times has cut a narrow flood-plain into the base of the terrace and deposited thereon a relatively thin layer of fine-grained alluvium. The deposit has little importance except insofar as it may affect the movement of water between the river and the underlying glaciofluvial material. Test wells for a possible water supply, drilled into the flood-plain several years ago by the City of Middletown, show the underlying material capable of yielding several hundred gallons of water per minute to individual wells.

4. Hydrology

In the remarks that follow, it is important to remember that the separation of hydrology into surface water and ground water is mainly for convenience of description and that the one is intimately related to the other.

\section{a. Surface Water}

The Connecticut River dominates the hydrology of the reservation. From the river will come virtually all the water required by the plant and into the river will go all the liquid waste discharged. At low water, the river is affected by tides from its mouth to Windsor Locks, a distance of 54 miles; in this reach, therefore, it is a drowned river or estuary. The government reservation is located about 24 miles up from the mouth of the river, or about 30 miles downstream from the tidal limit.

A report entitled, "The Salinity of the Connecticut River", was issued as Bulletin No. S- 1 by the W.P. A. for Connecticut, October, 1938. The report shows (a) that East Haddam (which is about 10 miles downstream from the reservation) is about as far upstream as saline water is likely to extend, (b) that during flood flows, saline water is altogether flushed out of the river, and (c) the usual location of the saline-fresh water contact is somewhere in the reach between Hadlyme and Essex (or approximately 13 to 20 miles downstream from the reservation). The location of the saline-fresh water contact is important because of the precipitating effect of saline water on suspended sediment. The sediment, in turn, probably would contain absorbed activity if such activity were to be discharged into the river.

The Connecticut River is gaged at Thompsonville, some 35 miles upstream from the reservation, and also near Middletown, some 3 miles upstream from the reservation. The Middletown gage provides discharge figures during periods of moderate to high stage only; in low stage the effect of tide makes discharge com- 
putation difficult. However, the Middletown gage provides a continuous record of river stage including tidal fluctuation which would be required in any special river study. A close approximation of discharge for all river stages at Middletown (which is practically the same as that at the reservation), may be computed from the record at Thompsonville by adding discharge from intervening tributaries. In this way, over 96 percent of the discharge at Middletown is accounted for. The following table shows the computation of average discharge at Middletown; daily discharge may be similarly computed from available records.

Approximate Average Discharge of the Connecticut River at Middletown (drainage area 10,870 square miles)

\begin{tabular}{|c|c|c|c|c|}
\hline tream & $\begin{array}{c}\text { Drainage } \\
\text { Area } \\
\text { (sq mi) }\end{array}$ & \multicolumn{3}{|c|}{ Discharge (cfs) } \\
\hline $\begin{array}{l}\text { River at Thompsonville } \\
\text { r at Broad Brook } \\
\text { River at Rainbow } \\
\text { at Hartford } \\
\text { iver near East Hartford }\end{array}$ & $\begin{array}{r}9,661 \\
98.4 \\
584 \\
74.0 \\
74.5\end{array}$ & $\begin{array}{c}282,000(a) \\
7,360 \\
29,900 \\
5,650 \\
5,160\end{array}$ & $\begin{array}{r}1,060 \\
16(\mathrm{~b}) \\
5(\mathrm{~b}) \\
4(\mathrm{~b}) \\
1(\mathrm{~b})\end{array}$ & $\begin{array}{r}15,910 \\
134 \\
1,000 \\
112 \\
111\end{array}$ \\
\hline otal & 10,490 & $\ldots$ & $\ldots$ & 17,300 \\
\hline
\end{tabular}

(1) Flood of March, 1936; elevation of flood crest at Middletown 28.2 feet above mean sea level.

(2) Discharge regulated by river control.

Thus it is seen that average discharge at Middletown is about 17, 300 cubic feet per second. Since only 96 percent of the drainage area is represented, actual average discharge probably is a little higher.

As stated, the Connecticut River is tidal at the reservation. The maximum range is about $21 / 2$ feet, decreasing with increasing river discharge. During periods of low discharge, usually in August and September of each year, the effect of tide is sufficient to cause reversal of river current. The maximum upstream velocity is believed to be about 1 foot per second. It is intended that measurements be made to determine (a) maximum distance from the reservation of upstream travel of tidal currents, (b) velocity distribution of currents at river cross-sections both above and below the reservation, and (c) the effect, if any, of tidal currents on movement of river bed material.

The remaining bodies of surface water on the reservation are Maromas Brook and Quarry Pond as previously described. Aside from noting that their total drainage area is about 1 square mile, little is known at present of their hydrologic characteristics. It is intended that the capacity of Quarry Pond both to store and to yield water be measured, and that the main discharge characteristics of Maromas Brook be measured. There is reason to believe that Maromas Brook, as it flows over the upper part of the terrace, loses water to the relatively permeable terrace material.

b. Ground Water

In bedrock, recoverable ground water occurs in interconnected open joints and cracks in the rock to a maximum depth of about $\mathbf{5 0 0}$ feet below land surface. In 
the overburden, recoverable ground water occurs in the interconnected pore spaces between the individual grains that make up the deposit, except that in till and perhaps in alluvium the pore spaces are so small as to make these deposits relatively impermeable.

The western hilly area underlain by rock and till is poorly drained, and (outside the reservation) numerous small swamps dot the countryside. Thus, the water table in this area appears to be close to the surface. It is also probable that Quarry Pond is fed by ground water from the surrounding bedrock and, therefore, the elevation of the pond surface also is the elevation of the water table at that place.

In the unconsolidated material of the terrace the water table lies much deeper. It appears to descend, almost with till, to nearly river stage. In a foundation boring drilled through the terrace the water table was encountered about 92 feet below the surface, till was encountered about 130 feet below the surface, and bedrock (gneiss) was encountered 138 feet below the surface.

It is not known whether or not the elevation of the water table in the terrace material is identical with that in the bedrock. It appears reasonable to suppose that the till acts as a confining layer and makes possible the existence of artesian water in the underlying bedrock. In this view, the elevation of the water table in the rock (or piezometric surface) would be the higher, and there would be a tendency for water in the rock to move up through the till and into the glaciofluvial material. The necessary head would be derived from the outcrop area in the hills immediately west of the terrace.

Although very few data are available relative to ground water movement, it appears possible to tentatively offer the following conclusions:

(1). The terrace material is isolated from surrounding aquifers. That is, ground water in the terrace under natural gradient discharges into the Connecticut River only. Ground water in the underlying rock might move to deeper rock horizons but, if so, the rate of movement is slow. Ground water in the terrace is prevented from entering underlying rock by the till layer, where such layer exists, and possibly by higher head of ground water in rock. The Connecticut River probably prevents ground water movement between the terrace at the government reservation and the terrace on the opposite side of the river.

(2) If ground water is pumped out of the terrace from wells penetrating below river stage, there is every reason to suppose that if the quantity pumped is large enough (say on the order of $100 \mathrm{gpm}$ ), the natural gradient to the river would be reversed and river water would enter terrace material.

(3) Pumping from anywhere in the terrace, including most, if not all, of the flood-plain along the terrace base, would tend to draw water both from the Connecticut River and also perhaps from all other parts of the terrace.

It is intended to drill observation wells and to conduct aquifer-performance (pumping) tests to obtain data on the shape of the water table and on aquifer characteristics. These data will make possible a more precise and accurate analysis of ground water movement. 


\section{Water Utilization}

The Connecticut River is navigable to barge and river boat traffic as far north as Hartford, or about $\mathbf{4 5}$ miles upstream from its mouth. The depth of channel is maintained by the U.S. Army Corps of Engineers at about 15 feet. Pleasure craft of all sizes use the river in increasing numbers. However, there is no public water supply in the State of Connecticut which takes Connecticut River water. At places, the water is used for industrial purposes, mainly for cooling. In summer, an unknown number of persons use the river for bathing and swimming. Fishing takes place on a small scale, much of it for individual sport. Commercial fishing on the Connecticut River is restricted mostly to the taking of shad during the period from about April 1 to June 15 , although yellow perch and eel are caught commercially at other times of the year. The average yearly shad catch by commercial fishermen is estimated by the State Board of Fisheries and Game to be about 100,000, and to be valued at about $\$ 100,000$.

Surrounding farms and homes obtain water supplies from individual wells, but with the possible exception of the supply well of the Hartford Electric Light Company steam plant near Benvenue, there appears to be no existing well supply that might be affected by future operations at the reservation. Wells on farms to be taken by the government are excluded from consideration. The City of Middletown drilled test wells in the flood-plain inside the north end of the (now) government reservation several years ago. The city has expressed interest in developing a well-field there, but so far no decision on the matter has been reached.

There are three open reservoirs in the hills a mile or so west of the reservation that supply a large state hospital. Since all are at elevations as high or higher than the highest part of the reservation, there is no possibllity for water-borne contamination to reach them.

It is intended to make an inventory of private water supplies in the vicinity of the reservation and along the Connecticut River. It is also intended to sample selected supplies for radioanalyses in advance of plant operation.

\section{Earthquake History of Connecticut}

The State of Connecticut is reported to have had twelve earthquakes which had their epicenters within the state boundaries. Undoubtedly more shocks have occurred, but they were not recorded because of their small areal influence and low intensity. The recorded shocks had intensities that varied from 4 to 8 on the Rossi-Forel scale of intensities. The Rossi-Forel scale of intensities classified earthquakes into ten groups according to their intensity at the epicenter. The recorded Connecticut shocks which varied from 4 to 8 in intensity would be described as follows:

Intensities

4

(feeble shock)

5 (shock of moderate intensity)
Description

Felt by persons in motion; disturbance of movable objects, doors, windows; cracking of ceilings.

Felt generally by everyone; disturbance of furniture, beds, etc.; ringing of some bells. 
Intensities

6 (fairly strong shock)

7 (strong shock)

8 (very strong shock)
Description

General awakening of those asleep; general ringing of bells; oscillation of chandeliers; stopping of clocks; visible agitation of trees and shrubs; some startled people leaving their dwellings.

Overthrow of movable objects; fall of plaster; ringing of church bells; general panic, without damage to buildings.

Fall of chimneys; cracks in walls of buildings.

The following table gives the date, location, square miles of area affected, and the intensity of the reported shocks:

Earthquakes of Record in the State of Connecticut

Date

May 16, 1791

August 28, 1791

January 11, 1792

March 6, 1794

August 11; 1805

August 23, 1827

April 12, 1837

August 9, 1840

June 30,1858

July 28, 1875

February 5, 1908

November 14, 1925
Locality

East Haddam

"1

11

"

New London

Hartford

Southern Conn.

New Haven

Connecticut

Housatonic Valley

Hartford

Lat. Long. Area

N W sq mi

Intensity

Distance from

$41.5 \quad 72.5 \quad 35,000$

$=$

$-$

$-$

$-$

41.4

41.7

$-$

41.5

41.3

41.8

$-$

$-$

41.5

72.7

72.7

72.9

73.0

73.2

72.5

72.5

-

-

$-$

-

$-$

$-$

7,500

1,000

2,000

$8, \overline{000}$

8

$-$

$-$

$-$

5

5

6

4-5

6

5

5 Middletown, mi

From the past records it would appear that there is little danger from earthquakes, but, inasmuch as they have occurred in the relatively recent past, it would be well to make sure that all structures that are to contain "hot" liquids or otherwise represent a hazard be constructed to withstand moderate shocks.

\section{REFERENCES}

Flint, R. F., 1930, The Glacial Geology of Connecticut: Connecticut Geological and Natural History Survey, Bulletin No. 47.

Heck, N. H., Earthquake History of the United States, Part I: United States Department of Commerce, Coast and Geodetic Survey Publication Serial No. 609.

United States Geological Survey, 1950, Surface Water Supply of the United States North Atlantic Slope Basins: United States Geological Survey Water-Supply Paper 1171.

Waring, G. A., 1920, Ground Water in the Meridan Area, Connecticut: United States Geological Survey Water-Supply Paper 449.

W. P. A., 1938, The Salinity of the Connecticut River: W. P. A. for Connecticut, Bulletin No. S-1. 